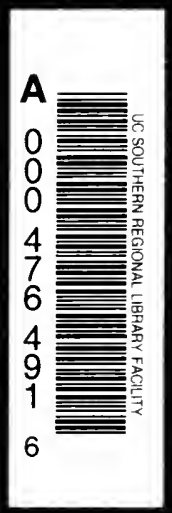




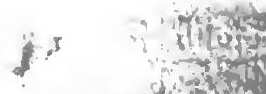

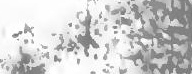

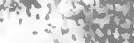
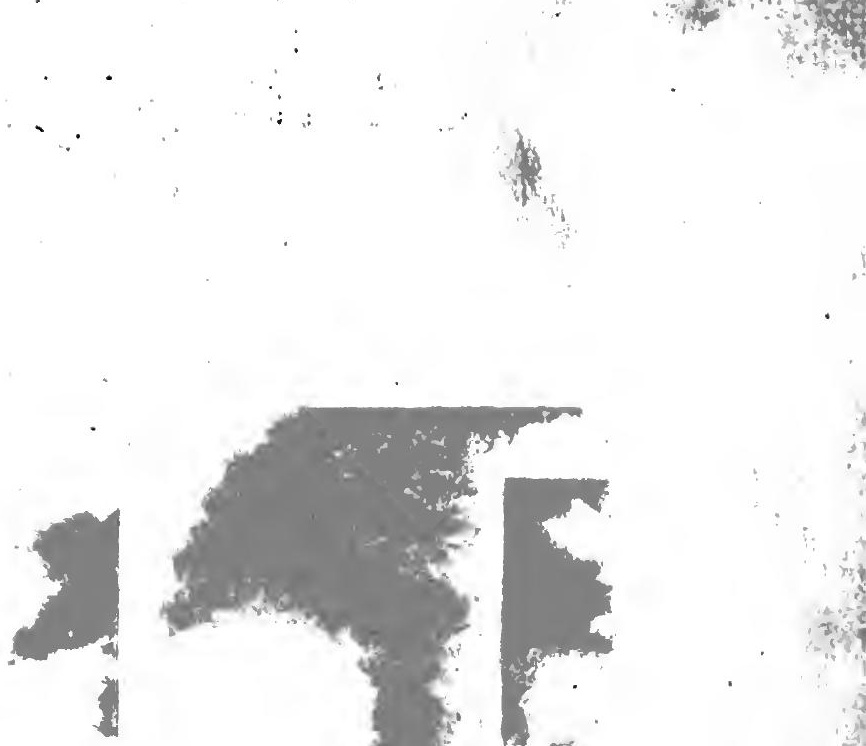

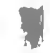
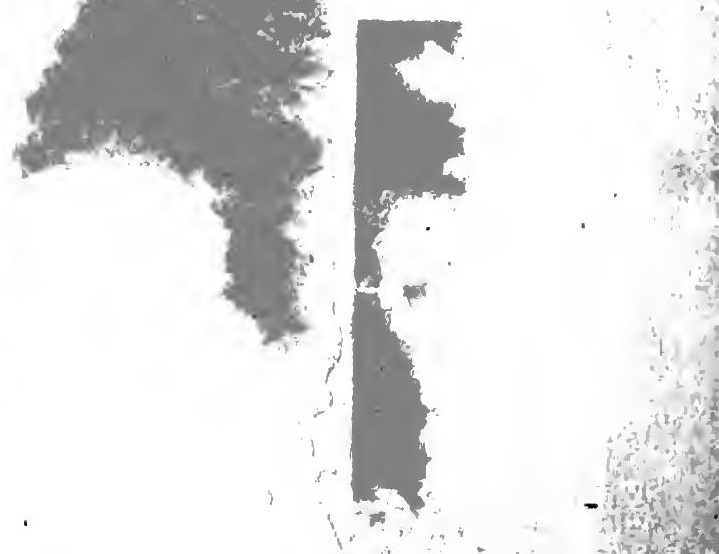

1.thy

A thangent of

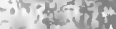

3.

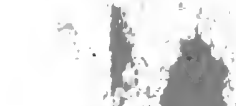

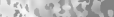

की

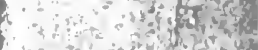

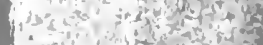
$\therefore$ astion as

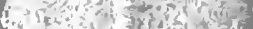
1.

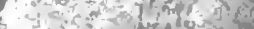

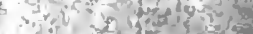
fetwit or sens? 
OATEN BRANCH, UNIVERSITY OF CALIFORNIA, LIBRARY, LOS ANGELES, CALIF.

apr 3-23

Ely. 


\section{Digitized by the Internet Archive in 2007 with funding from Microsoft Corporation}




\section{THE RURAL MIND AND SOCIAL WELFARE}


THE UNIVERSITY OF CHICAGO PRESS CHICAGO, ILLINOIS

THE BAKER \& TAYLOR COMPANY stw roRE

THE CAMBRIDGE UNIVERSITY PRESS

LONDOS

THE MARUZEN-KABUSHIKI-KAISHA

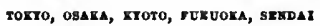

THE MISSION BOOK COMPANY

SHANOBAI 


\title{
THE RURAL MIND AND SOCIAL WELFARE
}

\author{
By ERNEST R. GROVES \\ Author of Using the Resources of the Country \\ Church, Rural Problems of Today, etc.
}

With Foreword

By KENYON L. BUTTERFIELD

President of Massachusetts Agricultural College

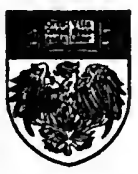

\section{2}

THE UNIVERSITY OF CHICAGO PRESS CHICAGO, ILLINOIS 
COPYRIGHT I922 BY

The University of Chicago

All Rights Reserved

Published June 1922

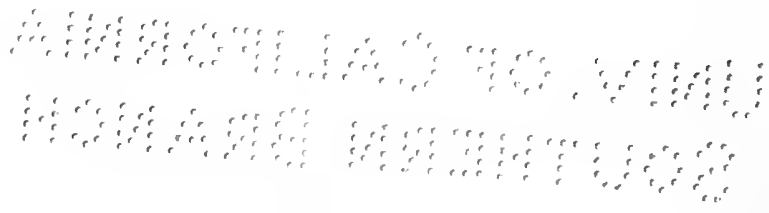

Composed and Printed By

The University of Chicago Press

Chicago, Illinols, U.S.A. 


$$
\begin{gathered}
117 \\
421 \\
591 \mathrm{rm}
\end{gathered}
$$$$
\text { TO }
$$

CATHERINE, ERNESTINE, AND RUTH 



\section{PREFACE}

The supreme need of our time is social sanity. Civilization has been shaken until at every point there are evidences of our social insecurity. Herdsuggestion was never more powerful nor more menacing. The ever-increasing drift of people to the cities provides, as the social psychologists, McDougall and Trotter, have pointed out, the ideal breeding-conditions for that crowdsuggestibility which more than anything else may endanger our convalescing civilization.

Those who call attention to the social risk involved in this movement of population to the cities assume that people who live in the country contribute to our national life influences of substantial social worth. The character of urban experience has been well analyzed and its social value is generally recognized. This book attempts to analyze in detail the rural social mind for the purpose of emphasizing its significance in our national life. Rural people have a greater social function than merely to grow food for city dwellers. They also contribute to modern society attitudes of mind of indispensable value. Not that country people are inherently different from city people. Living in a different environment they naturally 
develop characteristic habits of mind. National welfare needs their social influence, and for that reason the problem of rural prosperity is a matter of concern to all our people. Fortunately this fact is beginning to be recognized by all thoughtful leaders of public policies. The increasing attention which everywhere in the United States is being given to rural matters is based upon neither sentimental nor class interests. It does not represent selfish sectionalism. Rural welfare, on the contrary, is of national concern because it influences for good the country as a whole. The psychic contribution of the farming population is indispensable in our social life, for it provides mental qualities which urban people largely lack. As out civilization grows more urban we need all the more to appreciate the social value of rural experience.

Ernest R. Groves

Boston University

Boston, Massachusetts 


\section{CONTENTS}

FOREWORD - -

I. INTRODUCTION $. \quad . \quad . \quad . \quad . \quad . \quad . \quad$ I

The Psychological Era. Significance of the Instincts. Importance of Social Psychology. New Interest in Rural Psychology. Problem of Rural Psychology.

II. The Social Contribution of Primitive AgriCULTURE . . . . . . . . I

Social Influence of Agriculture. The Beginning of Agriculture. Savage Agriculture. Conditions of Agricultural Civilization. Mental Results of Agricultural Mode of Life.

III. City Drift

Complex Causes of City Drift. World-wide Character of City Drift. City Drift in the United States. Rural Depletion. Decrease in Rural Leadership Material. Social Advantageș of Balancing Rural and Urban Populations.

IV. Country Life and the Herd Instinct .

Social Appeal of the Urban Environment. Strength of the Gregarious Instinct. Unnatural Growth of Cities. Effect of the Great War upon the Gregarious Instinct. City Dictatorship and Prestige. Influence of Gregarious Tendencies upon Policieş of Government. Danger to Individualism. Significance of Suggestion. Craving for Intense Stimulation of Gregarious Life. Rural Reform and the Gregarious Instinct. 
V. The Instinct of Self-Assertion : • Self-Assertion and Social Evolution. SelfAssertion and Its Neurotic Expression. Theory of Adler. Self-Assertion in the Urban Environment. Class Struggle and Class Consciousness. Competitive Types in the Country. Village Prestige. Value of Rivalry in the Country. Self-Assertion and Rural Organization. Rural Welfare Demands Adequate Self-Expression for Farmers.

VI. The Parental and the Sex Instincts .

Parental Instinct and Social Organization. McDougall's Description. The Rural Family. Family Ambition and Rural Progress. Comradeship of the Rural Family. Competition between Rural Families. Pity in the Country. Influence of Sex upon Rural Social Conditions. Necessary Contact with Sex. Difference between Rural Communities in Regard to Sex Standards. The Rural Housekeeper Problem. Sex Sublimation in the Country.

VII. FEAR

Description of Fear. Fear in Primitive and Animal Life. Fear and Childhood. Rural Superstitions and the Child. Fear as Motive. Fear and Rural Organization. Fear and Isolation. Fear and Tragedies. Fear and Rural Consciousness.

VIII. Pugnacity, Currosity, Workmanship, AcquiSITION . . . . . . . 108

Rural Opportunities for Pugnacity. Pathological Quarrels in the Country. Curiosity and Isolation. Gossip. Curiosity and Agricultural Progress. Vigor of Instinct of Workmanship. 
Transitory Products of the Country. Community Spirit and Workmanship. Miser. Land Hunger. The Farmer and Property Rights.

IX. Play

Nature of Play. Play and Democracy. Play and Co-operation. Too Little Recreation in the Country. Social Risk of Denying Recreation. New Policy of Rural Church regarding Recreation. Inherent Limitations of the Rural Environment. The Problems of Recreational Policy. Rural Reading. Need of a Progressive Rural Library. The Farm Journals. The Daily Newspaper and the Rural Mind.

X. The Country Church and the Rural Mind I64 Social Importance of the Country Church. Difficulties of the Rural Pastor. Causal Character of Rural Experience. The Church and Childhood. The Rural Church and Rural Resources. The Social Character of the Program of the Country Church. The Social Responsibilities of the Rural Church.

XI. The Psychology of Rural Organization .

Psychology the Basis of Organization. The Beginning of a Rural Psychology. Organization in Its Relation to Gregariousness. The Strategy of Rural Organization. The Local Leader and Problems of Community Organization. Fear and Lack of Rural Organization. The Community Expression of the Instinct of Possession. Rural Organization and the Family. Organization and Rural Advancement. The Duplication of Rural Organizations. 



\section{FOREWORD}

When new enterprises on behalf of rural development are under consideration there are always those who remark that "farmers are no different from other people." This is one of those halftruths harmful chiefly because they form excuses for delaying progressive measures. Sometimes this particular error prevents the inauguration of adequate courses of study in agricultural schools and agricultural colleges. Sometimes it stands in the way of proper adaptation of a church program or a school curriculum to the needs of the countryside.

For the fact is that the farmers are different. They are not peculiar nor unique nor inferior. They are just different. They live under different conditions from city people; they think in different terms; they breathe a different atmosphere; they handle their affairs differently-perhaps because they have different affairs to handle.

This difference is not a difference in essential human qualities but merely the effect of environment upon inherent traits. Farmers are quite like other people in their fundamental instincts; but these instincts discharge through different channels from those that exist in the crowded city and 
hence bring oftentimes different results, so different as to produce the "rural mind."

In this book Professor Groves has indicated just what happens and why it happens. A scholar familiar with modern sociology, trained in psychology, a student of first-hand material in the rural field, for a long time teacher in an agricultural college, the author is eminently fitted to deal with this particular problem. He has given us a book at once scholarly and practical. Scholarly because it reaches down to grasp the best in social science; and practical because it gives validity to certain methods of rural organization and development. It is eminently a book for all rural leaders to read and to ponder.

KeNYON L. ButTERFIELd 


\section{INTRODUCTION}

This book is an analysis of the social experiences of country people. It attempts to bring together such psychological knowledge as at the present time is likely to prove useful in an understanding of the problems of rural life. It especially draws material from the rapidly developing social psychology. Although in the process of being made, social psychology already has established regarding the conduct of men and women facts and principles of great value in the interpretation of the rural environment.

The importance of the psychic side of country life fortunately no longer needs defense. The time was that scant attention was given to the mental elements in the rural environment even by leaders in country-life interests. Within the last ten years, however, in harmony with the increased emphasis that has been placed upon the psychological in every realm of life, students of rural affairs have been more and more concerned with the mental factors operating in rural society.

This is indeed the psychological era. We are all conscious of the large place in our social life given to the mental sciences. Every event has 
its psychological element. Psychic interpretation is never absent from any analysis of social phenomena. In our period psychological discussion holds the prominent place that formerly was occupied by biological science. Just as Darwin and his followers by their advancement of zoölogical science forced thinking people everywhere to give to evolution and its allied problems the central place in thought, so of late the valuable contributions made by men working on psychological problems in the various fields of the science have enabled us to see in a new and inviting way the enormous place in human society filled by the activities of the mind. It is being generally recognized that a new mine has been discovered rich with material of greatest value for the understanding of social experience. There is indeed a widespread conviction that it is folly to attempt any interpretation of man's social behavior unless we first of all do justice to the psychological influences which permeate it at every point.

Social psychology has especially stressed the instincts. Until recently they were relatively neglected because the instinctive character of man's social life was obscured by the fact that the human instincts express themselves in such complicated reactions as compared with the more simple behavior of the animal. Instincts furnish the basic raw material for man's social actions, but this is worked 
upon by experience and appears largely in the form of social habits. The primary place instincts hold in the social activities and desires of man is authoritatively expressed in these words:

The equipment of instincts with which a human being is at birth endowed must be considered in two ways. It consists, in the first place, of definite and unlearned mechanisms of behavior, fixed original responses to given stimuli. These are, at the same time, the original driving forces of action. An instinct is at once an unlearned mechanism for making a response and an unlearned tendency to make it. That is, given certain situations, human beings do not simply utilize inborn reactions, but exhibit inborn drives or desires to make those reactions. There is thus an identity in man's native endowment between what he can do and what he wants to do. Instincts must thus be regarded as both native capacities and native desires.

Instincts define, therefore, not only what men can do, but what they want to do. They are at once the primary instruments and the primary provocatives to action. As we shall presently see in some detail, human beings may acquire mechanisms of behavior with which they are not at birth endowed. These acquired mechanisms of response are called habits. And with the acquisition of new responses, new motives or tendencies to action are established. Having learned how to do a certain thing, individuals at the same time learn to want to do it. But just as all acquired mechanisms of behavior are modifications of some original instinctive response, so all desires, interests, and ideals are derivatives of such original impulses as fear, curiosity, self-assertion, and sex. All human motives can be traced back to these primary inborn impulses to make these primary inborn responses. ${ }^{\mathrm{x}}$

'I. Edman, Human Traits and Their Social Significance, pp. 18-rg. 
Although psychologists recognize the fundamental significance of man's instinctive behavior they do not at present agree in their classification of the human instincts. Some regard man as possessing two only-hunger and sex-while others distinguish twenty times as many. This difference of opinion in no way lessens the importance of man's instinctive behavior as it appears in his social life. The characteristic impulsive activities of the adult may represent indeed not a pure instinctive reaction but a more complicated composite of instinct and habit, which on that account is no less strong or automatic. One of our most skilled investigators states this fact as follows:

We are inclined to take the point of view here also that most of these asserted instincts are really consolidations of instinct and habit. In certain of them, such as manipulation, the original activities predominate. In certain others, e.g., adornment, hunting, habitation, etc., the pattern as a whole is largely composed of habit elements. It should again be reiterated here that so far as the functioning and value of these attitudes to the organism, so far as the rôle they play in daily life, so far as their backward and forward reference in the life history of the individual are concerned, it makes not a whit's difference what factors these capacities are analyzable into. The geneticist is likely to overemphasize the number of original tendencies; the psycho-analyst, to underestimate them. He reduces instincts almost as a class to a few stereotyped factors connected with the (from his standpoint, fundamental) sex phenomena. The fact of the matter seems to 
be that in most cases there is no need of detailed analysis of these attitudes. Those that we have cited and many others function as wholes in the daily lives of all individuals. They are as potent and real as if they were inborn and began to function in earliest infancy with all the completeness they exhibit in adult life. ${ }^{x}$

It is not to be expected that such a revolutionary movement as is represented by present social psychology would be welcomed with open arms by all those who feel themselves coming under the dominant interpretation of a vigorous science. In spite of our appreciation of the increasing importance of psychology, there are few who do not sense a degree of protest against the new interpreter of life. This inward irritation with respect to psychological explanation, of which there is evidence in every quarter, is another demonstration of the large place psychology now holds in the analysis of social life.

The significance of the recent progress in psychology consists in the fact that the frontier of causal science has once again been advanced. In the realm where causal explanation has been most uncertain and least satisfactory we are beginning to have an understanding of the laws governing mental experience. It is clear that the establishment of laws that explain conduct must have a very important influence upon the social life of the

'John B. Watson, Psychology from the Standpoint of a Behaviorist, pp. 261-62. 
future. Another step has been taken by man in his long historic effort to control for his own welfare the social environment in which his life moves and has its being. Although there may be exaggeration with reference to the certainties of our knowledge regarding mental behavior, and defenseless dogmatism on the part of some, there can be no question that the science is making rapid headway.

Psychology has invaded practically every field of human endeavor, yet no contribution coming from the science is of greater significance than that which is brought under the term social psychology. The former philosophical attempts at psychological interpretation with their individualistic point of view have been swept aside, and the entire science has come to look upon the individual as understandable only in his social relations. Social psychology, in a special way not possible to other branches of the science, has undertaken the interpreting and systematizing of the behavior of men and women.

In so far as social psychology has attempted to deal with concrete social problems it has devoted itself thus far almost exclusively to the urban field. This was inevitable. Urban problems have the center of the stage. Urban life is spectacular and dominating. Modern life exaggerates urban interests. Industry, which furnishes such a quantity of 
problems for psychological analysis, thrives in urban centers. We have as a result of these conditions an ever-increasing fund of knowledge, brought together by psychology in recent years, which is of the utmost value in understanding urban society.

The same influences that have given emphasis to urban matters have tended to hold rural experiences in the background. There is no rural psychology comparable to our urban psychology. This, however, is not because country life is destitute of problems or material for analysis, but merely because the science has relatively ignored the rural environment. For many reasons there has recently come to be an increased emphasis on rural welfare. From various motives and from many sources, men and women have seriously considered the needs of country folk. The prosperity and cultural attainment of country people is of such tremendous social significance that there is bound to be an increasing attention devoted to rural problems. In order that satisfactory progress can be made by rural sociology and rural economics, and especially by rural organization, there must be a rural psychology able to bring to the rural worker the same assistance the urban worker gets from the science. There is evidence that this fact is already recognized. Radical changes of thought with reference to the character of rural-life prob- 
lems have recently shown themselves in new and broader policies on the part of those interested in rural welfare.

Those who have undertaken responsibilities with reference to the economic and social wellbeing of the country are already recognizing that a rural psychology is seriously needed. More and more the mental side of the rural situation is receiving attention. We have traveled a long distance from the position formerly occupied by those who thought our only problem in the country was to make the farmer more skilful in his productive efforts. Rural statesmen are not only seeing the need of having psychological knowledge of rural problems, but are also beginning to value the psychological contributions that the rural people give to national and international society. Although the farmer is not isolated from the common influences of his time and place, and fortunately very largely shares the life that concentrates in the city, he nevertheless has his own peculiar experiences which have a psychic content. Because of this he is able to bring into national consciousness his own special psychic influences.

Any effort to construct a rural psychology must first of all recognize the character of the problem. Man brings to his environment inherited instincts which need to be adjusted to the demands placed upon them by the social life of those among whom 
he lives. This is the universal social problem present equally in the rural and urban environment. Rural psychology, therefore, must undertake to disclose the working of human instincts under the conditions provided in the country. Such an undertaking will necessarily disclose a considerable difference between the influences of the open country, the village, the suburban, and the city environment. In the country the problem of analysis is least difficult. To a large extent the working of the various instincts can be followed in detail and the environmental influence traced in the most simple environment with greatest certainty.

As a result of the building up of rural psychology, material will be brought together that must considerably influence every undertaking for rural welfare. Light will necessarily be thrown upon the work of the church and the school and the family. A more conscious control can be exercised over these fundamental institutions in their operations within the field of instinct. Most of all the programs for rural improvement will be influenced, and greater unity on the part of those who have at heart the good of the country will naturally follow. It is important, therefore, that psychology be attracted into the field of rural life and that every encouragement be given the science in its endeavor to build up a systematic understanding of the mental life of country people. 
As the science progresses in its ability to enter the rural environment, it will discover that a great part of its material is common to all country people the world over. Fundamental influences that coerce and transform, express and satisfy, the instinctive cravings of men and women in the country are neither local nor national. It will follow that the rural problem will never be conceived in narrow terms by well-trained students. It will not even be confirmed within the limits of nationality. When social psychology can analyze the elements common to all country people as a result of their environmental experiences, then we shall have a basis for international rural policies. Rural statesmanship will come under the momentum of a world-viewpoint.

\section{REFERENCES ON INTRODUCTION}

The references have been selected with a view to providing the reader with the material most likely to prove useful for additional study. Although few of them treat the rural mind specifically, each contributes something of value in its interpretation.

Edman, I., Human Traits and Their Social Significance, chap. ii. Boston: Houghton Mifflin Co., 1920.

Elliot, T. D., "A Psychoanalytic Interpretation of Group Formation and Behavior," American Journal of Sociology, November, I920.

Faris, E., "Are Instincts Data or Hypotheses ?" American Journal of Sociology, September, I92 I. 
Galpin, C. J., Rural Life, chap. ii. New York: Century Co., I9I 8.

Groves, E. R., "The Mind of the Farmer," Publications of the American Sociological Society, II, 47-53.

Hunter, W. S., "The Modification of Instinct from the Standpoint of Social Psychology," Psychological Review, July, 1920.

McDougall, W., An Introduction to Social Psychology, chaps. i, ii, and iii. Boston: Luce \& Co., I918.

Park, R. E., and Burgess, E. W., Introduction to the Science of Sociology, pp. 73-85. Chicago: University of Chicago Press, I92I.

Parmelee, M., Science of Human Behavior, chap. xiii. New York: Macmillan, I9I3.

Tansley, A. G., The New Psychology and Its Relation to Life, chap. xvii. New York: Dodd, Mead \& Co., I920. Tead, O., Instincts in Industry, chap. i. Boston: Houghton Mifflin Co., I9I8.

Vogt, P. L., Introduction to Rural Sociology, chap. x. New York: Appleton, I9I 7 .

Watson, J. B., Psychology from the Standpoint of a Behaviorist, chap. vii. Philadelphia: Lippincott, I9r9.

White, W. A., The Mental Hygiene of Childhood, chap. ii. Boston: Little, Brown \& Co., I9I9. 


\section{II}

\section{THE SOCIAL CONTRIBUTION OF PRIMITIVE AGRICULTURE}

The evolution of agriculture reveals social and psychic consequences of the greatest importance. No discovery has had such significance for human society as did the first planting of seed for the purpose of harvest. Such evidence as we have of the obscure beginning of agriculture points to Asia as its place of origin. However simple in its first stages the planting may have been, it started influences that were destined to revolutionize man's mental and social habits. The lessening of the hunter's mind traits and the coming of the farmer's represents in its social results the greatest psychic epoch in human culture. From the beginning primitive agriculture illustrated the psychological influences of the farming vocation by the contributions it made to the developing social mind of those who learned the advantage of getting food supply by the cultivation of the soil.

Civilization and agriculture are indissolubly linked together. It was by means of the gradual development of an agricultural mode of life that primitive man was able to arrive at a degree of social permanency. The tremendous significance 
of this transition from a wandering existence deeply impressed racial tradition and led the thinking of antiquity to ascribe to agriculture a divine origin. Brahma in Hindustan, Isis in Egypt, Demeter in Greece, and Ceres in Italy were credited with the founding of agriculture.

In evolutionary history agriculture in its beginnings goes back to Neolithic man. In the distinctive features of the Neolithic epoch the most important economic progress consisted in a rudimentary knowledge of agriculture. By the use of crude implements, gradually introduced, a simple cultivation of a few plants and seeds became possible, and an increased food supply. As a result of this larger and more stable food supply Neolithic man was led away from his nomadic mode of life to a more or less permanent settlement. ${ }^{x}$

Savage man's widespread custom of offering a human sacrifice or of performing at seed-planting time ceremonies that are vestiges of former sacrificial practices suggests that primitive agriculture may have originated in connection with the burial of the dead. ${ }^{2}$ The graves were necessarily shallow due to the inadequate tools for deep digging, and the earth was often heaped over the dead, forming mounds. The food material, especially wild grains, buried with the dead or placed upon the mound

$x$ Osborn, Men of the Old Stone Age, p. 496. -

${ }^{2}$ Frazer, Golden Bough. 
may have resulted in the first sowing of seed and given rise in the primitive mind to the idea that the plants which later appeared and bore fruit were expressing the life of the departed. It would follow that when the thought of deliberately sowing for a harvest later arose, the ceremonial burial in some form or other would continue as a necessary part of harvest preparation.

In the more recent experience of savage peoples we find illustration of primitive man's entrance upon the agricultural life. Writing of the Papuans of New Guinea and of the Torres Straits a modern authority gives this vivid description of the change from the mobile to the semi-settled life:

The Papuans are the first to change the digging-stick into the hoe, a useful implement in tilling the soil. In this first form of the hoe, the point is turned so as to form an acute angle with the handle to which it is attached. Hence the soil is not tilled in the manner of the later hoe-culture proper; nothing more is done than to draw furrows into which the seeds are scattered. In many respects, however, this primitive implement represents a great advance over the method of simply gathering food as practised when the digging-stick alone was known. It is the man who makes the furrows with the hoe, since the loosening of the ground requires his greater strength; he walks ahead, and the woman follows with the seeds, which she scatters into the furrows. For the first time, thus, we discern a provision for the future, and also a common tilling of the soil. The gathering of the fruits generally devolves upon the woman alone. But even among the Papuans this first 
step in the direction of agriculture is found only here and there. The possibility of external influences therefore remains. ${ }^{\mathrm{I}}$

Primitive soil cultivation was of course at first of the simplest character. It consisted perhaps merely in protecting the growing plants until matured and then harvesting them. When the food supply became exhausted the settlement moved to another site.

An interesting illustration of this primitive type of agriculture appears in a recent description of Stone Age conditions in Dutch New Guinea. ${ }^{2}$ The valuable study that has been made of the gathering of wild rice by the North American Indians of the Upper Lakes pictures the same type of agriculture carried on by people of a somewhat higher culture. ${ }^{3}$

Before any considerable progress in the cultivation of the soil could ensue certain indispensable conditions had to be brought about. First of all there had to be a suitable climate and soil. In addition the higher mode of life required protection from the warring enemy ever ready to plunder, a degree of security from insect pests, a fixed settlement, and, most important of all probably, pressing need of food. The conditions of savage life as

'Wilhelm Wundt, Elements of Folk Psychology, p. 126.

${ }^{2}$ Wollaston, Pygmies and Papuans. The Stone Age Today in Dutch New Guinea, p. Iог.

3 Jenks, "The Wild Rice Gatherers of the Upper Lakes," Bureau of American Ethnology Reports, XIX, IоI3-I I37. 
revealed by travelers and scientists are such as to make agriculture, even when started, a hazardous undertaking. Insect pests, especially in the tropics, make the harvesting and storing of food exceedingly difficult and at times impossible. ${ }^{x}$ The enemy is seldom absent. With rude tools the task of clearing land and keeping it clear is something even civilized man would hesitate to assume. Habits formed by nomadic existence rebel against the ordeal of a settled life.

The transition to a feeble beginning of the agricultural life is usually forced upon savages by the need of food. ${ }^{2}$ The savage learns the value of plants and discovers the possibility of their cultivation before he is equal to the foresight, patience, and drudgery required by soil cultivation. Even when he begins to get his food supply from the growing of vegetables he still hunts and fishes for the greater part of his provisions. Since the savage, wherever we find him living at his lowest level of culture, places the burden of gathering vegetable food upon the woman it seems safe to suppose that primitive man's first step toward the agricultural mode of life resulted from the drudgery that was forced upon the woman.

However haphazard and meager the beginning of the conscious use of soil for plant cultivation, it

${ }^{x}$ Wollaston, op. cit., pp. 58-59.

${ }^{2}$ Thomas, Source Book for Social Origins, pp. 65-66. 
marked a very great social advance and one that had the strongest influence upon the habits of primitive man. The effect of vocation upon the civilized individual is well recognized. Doctor, lawyer, engineer, farmer, each has certain characteristics which are the product of his vocational experiences. In a far greater degree, by changes difficult to imagine, the giving up of an exclusive interest in hunting, fishing, or even cattle-breeding as a means of food production and the turning to the raising of vegetables created for primitive man a new set of vocational habits of the largest consequences for social development.

The dramatic factor of the hunt was by slow gradations discounted for the greater advantages of a more reliable and abundant source of food. The distance between hunger and the means of procuring food for its satisfaction widened, and it became possible for the attention to turn to the process itself. It is this separation between the present stimulus of hunger and the activities it prompts with the hope of future satisfaction that furnishes opportunity for those mental and social traits to develop that are the basis of the civilized conditions of life. Self-control in undertaking labor which was not expected immediately to bring its rewarding satisfactions, increasing attention to the slow processes by which plant food is provided, inventive skill in devising more and more useful 
tools, greater sense of prudence in the attempt to store food-these were some of the mental products of the coming of the new vocational experience.

The tendency to linger at a settlement, the acceleration of the development of the division of labor, on a sex basis at first, the growth in the idea of property and law - these were among the important social products of the higher agrarian culture. These social advantages were meager, however, until men as well as women took up the task of tilling the soil. We find sometimes among savages that a part of the agricultural work may be carried on by men and the balance by the women. For example, among the Mafulu peoples of New Guinea, Williamson ${ }^{\mathrm{I}}$ describes a division of labor which puts upon the men the cutting down of trees and the making of fences, while the clearing of the underbrush is put upon the women. It is likely that stern necessity forced primitive man to make use of his superior strength in providing for the women an opportunity to carry on their simple form of agriculture. Everything we know about the savage teaches us that the primitive male could not have taken kindly to the new vocational experiences thrust upon him. The reason is obvious. He was turning from a means of food-getting that made a tremendous appeal to his instincts and was attempting tasks for which his training

${ }^{x}$ R. W. Williamson, The Ways of the South Sea Savage, p. 233. 
and mental equipment made him unfit. This readjustment of vocation-habits was the most difficult and the most important man ever has undertaken. To value it aright in its social consequences one must regard it not merely as providing a better source of food; its significance as a teacher of new attitudes of mind and new modes of social experience must also be appreciated.

The rapid and radical social change in savage society due to the introduction of agriculture is well brought out by the following description of Major Leonard's:

With the progress from a hunting life to agriculture an improvement and development had taken place in the social scale. The families, or first social units, had increased and multiplied, and necessitated a further extension of premises and a greater area for cultivation. This expansion of the units, as in the previous stage of development, but in increasing ratio, had developed into communities which necessitated greater demands, among which religious and moral principles figured most prominently. ${ }^{\mathrm{I}}$

The mental factors developed with hunting and fishing habits could not be utilized to any extent under an agricultural régime, but they did not pass out of human history an utter loss. As has been pointed out by John Dewey, ${ }^{2}$ they found new expression. In the words of present-day psychology they were sublimated. In place of hunt-

I A. G. Leonard, The Lower Niger and Its Tribes, p. ror.

'Thomas, op. cit., p. 186. 
ing animals for food, and other humans for the satisfaction of killing them, new forms of pursuit originated. When the development of agriculture reached a stage that permitted the gathering of such a surplus of food.as made possible the city with a population dependent upon outside support for sustenance, then the spirit of the hunt was given an adequate vocational expression by the pressure and competition of urban life. Business especially offered the zest and struggle and even the craft of the hunter's life. The dramatic appeal of primitive life was more than matched by the satisfactions of commercial competition. Even the pleasure of contests with the enemy was provided by the antagonisms of classes.

The ancient handicap of the agricultural vocation still remains. From a hunter's viewpoint it is even yet a prosaic occupation and in large measure likely so to continue. It has a dramatic element in the never-ending struggle of the wits of man against the untoward happenings of season and climate, but the average imagination cannot grasp this form of contest so easily as it does the spectacular conflicts furnished by the commercial strife of man against man in the cities.

The theory ${ }^{\mathrm{T}}$ has been advanced that this difference in the appeal of country and city vocations has tended toward an ethnic stratification in Cen-

${ }^{x}$ Ripley, Races of Europe, pp. 537-59. 
tral Europe. The head shape that characterizes the Teutonic racial type, it is claimed, is more commonly found in the urban population, the broad-headed representative of the Alpine race being predominantly rural. In this stratification of race head forms are included mental traits. The Alpine type is defined as rural-minded, tenacious in its grip upon the soil. It represents conservatism and is indisposed to migrate. To this racial type belongs the peasant. On the other hand the mobile Teuton, the long-headed type, loves the city with its opportunity for energetic competition and for dominance. Therefore, when within any territory there is a considerable mingling of the two races, he furnishes the greater part of the urban population. This theory, which is by no means an established fact of science, calls attention to the natural attractiveness of the city for the more pugnacious and domineering individuals of a population. Those who are by instinct fitted for a struggle with persons must seek urban conditions for their highest social satisfaction. The other type, on the contrary, firm in a primitive love for the soil and well equipped for a patient but ceaseless contest with nature, is most at home in the small village or open country.

The hunter has by no means limited himself in modern life to business and class competition. The mental cravings typical of the hunter find frequent 
and periodic expression in warfare. How deep these cravings are and how persistent is clearly shown by the large place war holds in the record of modern history. Since the first appearance of agriculture human nature has suffered a social dualism. 'The hunter-warrior's impulses have made for war; the shepherd-farmer's for peace. 'The average modern man finds himself impelled toward the captivating emotional orgasm of war and also toward the pleasures and opportunities of the orderly and productive life of peace. The normal influence of rural experience tends toward peace and attainment of satisfaction by productive labor. The urban mind is more easily inflamed into the war mind and started upon a violent career. War draws out the impetuous impulses of the hunter's disposition, and with the return of peace the citizen turns to ordinary occupations with relief. It is in terms of war, however, that he still expresses his profound political loyalty, and from war experiences that he constructs his strongest traditions. As the agriculturists little by little narrowed the hunter's territory by bringing the soil under permanent cultivation, so the social mind originating from the farming experience makes slow headway against the powerful appeal of war upon man's most primitive and irrational cravings.

I "A Rustic View of War and Peace," Papers for the Present, p. 22. 
REFERENCES ON THE SOCIAL CONTRIBUTION OF PRIMITIVE AGRICULTURE

Bordeau, L., "The Beginnings of Agriculture," Popular Science Monthly, XIVI, 678-88.

Elliot, G. F. S., Prehistoric Man and His Story, chaps. xii, xiii. London: Seeley, Service \& Co., 1920.

Hobhouse, L. T., Wheeler, G. C., and Ginsberg, M., The Material Culture and Social Institutions of the Simpler Peoples, chap. i. London: Chapman \& Hall, I915. Jenks, A. E., "The Wild-Rice Gatherers of the Upper Lakes," Bureau of American Ethnology Reports, XIX, IOI3-I I37.

Kroeber, A. L., and Waterman, T. T., Source Book in Anthropology, pp. 245-52. Berkeley: University of California Press, I920.

McGee, W J, "The Beginning of Agriculture," American Anthropologist, October, 1895, pp. 350-75. "The Beginning of Zooculture," American Anthropologist, July, I897, pp. 215-30.

Osborn, H. F., Men of the Old Stone Age, pp. 496-99. New York: Scribner's, Igig.

Ratzel, F., The History of Mankind (A. J. Butler, transl.), I, 87-93. London: Macmillan, I896.

Roth, H. L., "On the Origin of Agriculture," Journal of the Anthropological Institute, August, 1886, pp. 102-36. 


\section{III}

\section{CITY DRIFT}

The most significant movement of population today in both Europe and America is the constant migration of people from the country to the cities. This population drift, one of the many results of modern industrialism, is of the greatest social consequence. It portrays economic and social motives that indicate an increasing urbanizing of civilized people everywhere. An impetus toward the urban concentration of people, started by the industrial development of the last century, is greatly stimulated by the social conditions of the twentieth century. This movement, already excessive, is becoming still more pronounced as a result of conditions created by the experiences of the world-war; and everywhere rural statesmanship is attempting to cope with the problem.

The drift of rural people to the cities appears to be even greater in Europe than in this country. Most of the European cities have been growing faster than our own. In Germany, France, and England especially a constant depopulation of the rural districts is more and more making Europe one vast urban area. From I88I to I89I the French cities of thirty thousand inhabitants or over added 
to their respective numbers more than three times as many as the total increase of population for the entire country. In the same period Paris absorbed four-fifths of the entire increase of population of France during the decade. ${ }^{\mathrm{I}}$ For France as a whole the rural population has decreased during the sixty years between 1846 and 1906 as much as $16 \frac{2}{3}$ per cent. $^{2}$

We have startling testimony from a student and lover of rural England regarding city drift in his country:

When we turn to the question of the decrease in the inhabitants of English rural districts, it is to find ourselves confronted with some startling figures. I read that in I85 I the agricultural labourers of England and Wales numbered $1,253,800$ and that in 1891 they had shrunk to about 780,700 . What the census of rgor shows their number to be I do not yet know, but I shall be much surprised if it records any advance. Taking it on the $189 \mathrm{r}$ basis, however, it would seem that whereas between $185 \mathrm{I}$ and I89 I the population of England and Wales had increased by about a half, its agricultural inhabitants during this same period had actually decreased by over one-third, with the result that whereas in $189 \mathrm{r}$ the urban districts could show a total of about $25,000,000$ people, the rural districts held only about $7,500,000$, that is, some 23 per cent of the population, as against 77 per cent living in towns or their immediate neighbourhood. These figures are very eloquent and very ominous, especially if a careful analysis of those of the

${ }^{x}$ Ripley, The Races of Europe, p. 540.

${ }^{2}$ Second Wisconsin Country Life Conference, p. II 2. 
last census should prove them to be progressive in the same directions. ${ }^{\mathrm{I}}$

In days that are quite recent, as the remarkable Necton document quoted in my chapter on Norfolk shows, folk were haunted by an absolu te terror of the over-peopling of the rural districts. Now they suffer from a very different fear. The plethoric population-bogey of 1830 has been replaced by the lean exodus-skeleton of I902. People are deserting the villages wholesale, leaving behind them the mentally incompetent and the physically unfit; nor, at any rate in many parts of England,-although in this matter East Anglia is perhaps better off than are most other districts, does the steady flow to the cities show signs of ceasing. Yet-and this is one of the strangest circumstances connected with the movement-those cities whither they go are full of misery. Disease, wretchedness, the last extremes of want, and the ultimate extinction of their families will be the lot of at least a large proportion of these immigrants. ${ }^{2}$

It is interesting to find in a country as rural as Sweden the same urban trend. A recent report of the Swedish government states that

if instead of being bound by legal distinctions between town and country, one counts as towns all well-populated places of at least 2,000 inh., the entire town population

I Distribution of urban and rural population of England and Wales in I901 and I9II (Statesman's Year Book, I921, p. 19):

\begin{tabular}{|c|c|c|c|}
\hline & 1901 & IgII & $\begin{array}{l}\text { Percentage } \\
\text { of Increase }\end{array}$ \\
\hline $\begin{array}{l}\text { Total urban........................ } \\
\text { Total rural.... }\end{array}$ & $\begin{array}{r}25,351,118 \\
7,176,725\end{array}$ & $\begin{array}{r}28,162,936 \\
7,907,556\end{array}$ & $\begin{array}{l}11.1 \\
10.2\end{array}$ \\
\hline
\end{tabular}

${ }^{2}$ Sir Rider Haggard, Rural England, pp. 565-66. 
probably rises to about $\mathrm{r}, 685,000$, corresponding as nearly as may be to 30 per cent of the population. . . . .

The urban population during the nineteenth century increased from scarcely so per cent of the whole population to more than $2 \mathrm{I}$ per cent. This advance, however, does not begin until the decade beginning $\mathrm{I} 84 \mathrm{I}$, after the abolition of the old guild corporations ( 1846 ); since then the population of the towns of Sweden has increased at an unusually rapid rate, far quicker than in Western Europe generally; during quite recent times, since the end of the last century or somewhat later, the increase of urban population, in spite of important incorporations, has gone on somewhat slower, that of rural districts somewhat faster than during the few previous decades. This is chiefly due to the fact already pointed out, that by the side of the old, legally acknowledged towns, new places similar to towns arose, sometimes as suburbs, but often enough as new independent town organizations, or the beginnings of them. The next generation, therefore, will see, in all probability, a great increase in the urban population of Sweden. ${ }^{\mathrm{x}}$

Canada with its vast stretches of fertile land might be expected to escape the world-wide urban trend of population, but, as a matter of fact, the Canadian cities are growing at the expense of the country districts. This fact is impressively revealed by MacDougall's study of Canadian rural life. He reports that the country people formed in Canada according to the census of r9or, 62.4 per cent of the total population; in I9I I they had fallen to 54.4 per cent. The city population, 37.6

× J. Guinchard, Sweden, Vol. I, p. Irg. 
in I90I, had increased to 45.6 in I9I I. He gives the following evidence of the urban trend in Canada:

The proportion of rural to total population has fallen in every Province during the decade; in Prince Edward Island from 85 per cent to 84 ; in Saskatchewan from 80 to 73 per cent; in New Brunswick from 76 per cent to $7 \mathrm{I}$; in Manitoba from 72 to 56 per cent; from 71 per cent to 62 in Nova Scotia and in Alberta; from 60 to 51 per cent in Quebec; in Ontario from 57 per cent to 47 ; and in British Columbia from 49 to 48 per cent. ${ }^{\mathrm{I}}$

Assuming that the natural increase of population is I. 5 per cent per annum, the rural population of the Dominion in I90I, 3,349,5 I 6 , should have increased by 547,878 before the census was taken in I9II. Of the I, 715,326 immigrants who came to Canada during the decade, approximately one-third at the ports of entry gave farming as their occupation. These, with the same annual rate of increase, give a further augment of 670,258 . The rural population thus received an accretion of $1,218,136$. The actual growth was 574,878 . Therefore 643,258 persons left our country districts during the decade. ${ }^{2}$

The magnitude of city drift in the United States is disclosed by the tables given on page 29 , from the report of the census of I9Io:

For the interpretation of these tables the reader must bear in mind that the population residing in cities or incorporated places of 2,500 or more inhabitants, including New England towns of that

'John MacDougall, Rural Life in Canada, p. 23.

${ }^{2}$ Ibid., p. 29. 
size, was classified as urban. Outside New England towns of 2,500 people or more are usually RURAL AND URBAN POPULATION OF THE UNITED STATES, $1880-1910^{*}$

\begin{tabular}{|c|c|c|c|c|c|c|c|}
\hline \multirow{2}{*}{ YEAR } & \multicolumn{3}{|c|}{ Number } & \multicolumn{2}{|c|}{ Percentage } & \multicolumn{2}{|c|}{$\begin{array}{l}\text { PERCENTAGe } \\
\text { OF INCREASE }\end{array}$} \\
\hline & Total & Urban & Rural & Urban & Rural & Urban & Rural \\
\hline $\begin{array}{l}\text { I910.. } \\
\text { I900.. } \\
\text { I890.. } \\
\text { I } 880 . .\end{array}$ & $\begin{array}{l}91,972,266 \\
75,994,575 \\
62,947,7 \text { I4 } \\
50,155,783\end{array}$ & $\begin{array}{l}42,623,383 \\
30,797,185 \\
22,720,223 \\
14,772,438\end{array}$ & $\begin{array}{l}49,348,88_{3} \\
45,197,390 \\
40,227,491 \\
35,383,345\end{array}$ & $\begin{array}{l}46.3 \\
40.5 \\
36.1 \\
29.5\end{array}$ & $\begin{array}{l}53.7 \\
59.5 \\
63.9 \\
70.5\end{array}$ & $\begin{array}{c}38.3 \\
35 \cdot 5 \\
53.8 \\
\ldots \ldots\end{array}$ & $\begin{array}{r}9.1 \\
12.3 \\
13.6 \\
\ldots \ldots\end{array}$ \\
\hline
\end{tabular}

*United States Census, roro, "Population," p. 53.

PROPORTION OF THE POPULATION OF THE UNITED STATES, IN CITIES OF 8,000 OR MORE, 1790-1910*

\begin{tabular}{|c|c|c|c|c|}
\hline Year & $\begin{array}{l}\text { Number } \\
\text { of Places }\end{array}$ & $\begin{array}{c}\text { Percentage } \\
\text { of Increase } \\
\text { Each Decade }\end{array}$ & $\begin{array}{l}\text { Percentage } \\
\text { of Total } \\
\text { Population }\end{array}$ & $\begin{array}{l}\text { Percentage } \\
\text { of Increase }\end{array}$ \\
\hline Igro......... & 778 & 39.8 & $3^{8.8}$ & $5 \cdot 7$ \\
\hline Igoo.......... & $55^{6}$ & 23.8 & $33 \cdot \mathrm{I}$ & 4.0 \\
\hline I890........... & 449 & 54.2 & 29.1 & 6.3 \\
\hline I880.......... & $29 I$ & 28.7 & 22.8 & I. 9 \\
\hline $1870 \ldots \ldots \ldots$ & 226 & 60.2 & 20.9 & 4.8 \\
\hline $1860 \ldots \ldots \ldots$ & I4I & $6_{5} .8$ & I6. I & 3.6 \\
\hline $1850 \ldots \ldots \ldots$ & 85 & 93.1 & $12 \cdot 5$ & 4.0 \\
\hline $1840 \ldots \ldots \ldots$ & 44 & 69.2 & 8.5 & $\ldots \ldots \ldots$ \\
\hline $1830 \ldots$ & 26 & 100.0 & 6.7 & $\ldots \ldots \ldots$ \\
\hline I820........ & I3 & I8. I & $4 \cdot 9$ & $\ldots \ldots \ldots$ \\
\hline I810..... & I I & $83 \cdot 3$ & $4 \cdot 9$ & $\ldots \ldots \ldots$ \\
\hline $1800 \ldots$. & 6 & 0.0 & 4.0 & $\ldots \ldots \ldots$ \\
\hline I $790 \ldots \ldots \ldots$ & 6 & $\ldots \ldots \ldots$ & $3 \cdot 3$ & $\ldots \ldots \ldots$ \\
\hline
\end{tabular}

*United States Census, 1910, "Population," p. 54.

incorporated. In six states of the Union, Vermont, New Hampshire, Ohio, Indiana, Iowa, and 
Missouri, the rural population, including village population, decreased.

An attempt has been made by Professor John M. Gillette to proportion the different elements responsible for the growth of the American cities, and his investigation, based upon the census report of I9Io, accounts for the urban increase under the four heads: incorporation, or the addition of urban territory, immigration, natural increase of city population, and rural migration. His results are expressed in the following table:

FACTORS OF URBAN INCREASE FOR THE UNITED STATES AS A WHOLE, 1900-1910*

\begin{tabular}{|c|c|c|}
\hline Factor & Amount & $\begin{array}{l}\text { Percentage } \\
\text { of Urban } \\
\text { Increase }\end{array}$ \\
\hline 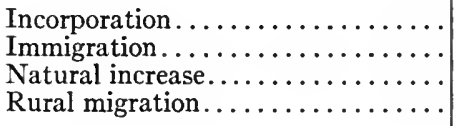 & $\begin{array}{r}924,000 \\
4,849,000 \\
2,426,000 \\
3,637,000\end{array}$ & $\begin{array}{r}7.8 \\
41.0 \\
20.5 \\
30.7\end{array}$ \\
\hline 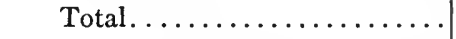 & I I $, 826, \infty 00$ & 100.0 \\
\hline
\end{tabular}

* John M. Gillette, "A Study in Social Dynamics," Quarterly Publications of the American Statistical Association, December, 1916, p. 365.

The author obtains by a different method of analysis $3,275,000$ as the minimum estimate of the amount of rural migration for the decade and concludes that the true estimate would fall between the minimum and maximum figures, or about $3,500,000$. 
Detailed statistics concerning the urban and rural population, based on the census of 1920 , are being compiled but are not completed. In a preliminary announcement, however, Director Rogers has made public the following:

/ The figures of the present census also show that the trend of population from the country to the city has become greatly accentuated since I9IO and that, for the first time in the country's history, more than half the entire population is now living in urban territory as defined by the Census Bureau. That is to say, of the $105,683,108$ persons enumerated in the Fourteenth Census, preliminary tabulations show that $54,816,209$, or 51.9 per cent, are living in incorporated places of 2,500 inhabitants or more, and 50,866,899, or 48.1 per cent, in rural territory.) At the census of I910 the corresponding percentages were 46.3 and 53.7 , respectively, showing a loss of 5.6 per cent in the proportion for the population living in rural territory. To show more clearly the change in the proportion of the population living in rural territory now as compared with ten years ago, the rural population can be divided into two classes, namely, $9,864,196$, or 9.3 per cent of the total population living in incorporated places of less than 2,500 inhabitants, and $4 \mathrm{I}, 002,703$, or 38.8 per cent of the total population living in what may be called purely country districts. At the census of rgro, the population living in incorporated places of less than 2,500 inhabitants formed 8.8 per cent, while the population living in purely country districts formed 44.8 per cent of the total population.

The increase since 1910 in the population as a whole, as before stated, was 14.9 per cent, but during the decade there has been an increase in that portion of the population living in urban territory of $\mathrm{x} 2,192,826$, or 28.6 per cent, 
and in that portion living in rural territory of 1,5 I 8,0 I 6 , or only 3.I per cent; and if the comparison is extended to cover the two classes of rural territory, it appears that that portion living in incorporated places of less than 2,500 inhabitants shows an increase of $1,745,37 \mathrm{I}$, or 21.5 per cent, whereas that portion living in purely country districts shows an actual decrease of 227,355 , or six-tenths of I per cent.

A survey recently made of the town of Sandwich, New Hampshire, disclosed the influence of the development of manufacturing in New England upon the destiny of a community which has always been strictly rural. The year 1830 represented the beginning of an era of industrial prosperity in New England, ${ }^{\mathrm{I}}$ and the population reported at Sandwich for that year is its maximum. From that time the growth of urban manufacturing and trade started a migration which has not yet ceased. The following table makes this clear.

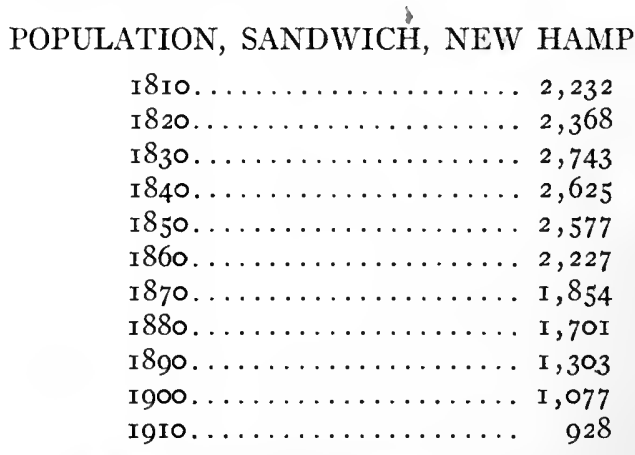

'Population Growth in Southern New England. American Statistical Association Publication. 
A striking fact with reference to the city drift is the greater migration of females than males. Merritt ${ }^{\mathrm{x}}$ states that "in practically all countries there is an excess of males in the rural districts and when we compare by sex and by age groups the percentage of the total population living in rural districts we find an excess of men at all ages." In the United States there is, however, one exception. The predomination of middle-aged negro females in the rural sections of the South causes in most of the counties an excess of negro females. In the other age groups the negro males predominate. In Europe, where agriculture is carried on without machinery, there is an excess of females in the rural parts; where modern machinery is largely used males predominate.

A very important question arises with reference to our national city drift. In how far does this migration mean a depletion of population vitality? Does it represent a survival in the rural districts of people socially less efficient than those who move to the cities? Professor Edward A. Ross made in I9I I a walking trip through certain parts of rural New England for the purpose of studying the social life of communities that for some time had been decreasing in population. He found that

I Merritt, "Agricultural Element in the Population," Quarterly Publications of the American Statistical Association, March, 1916, p. 56. 


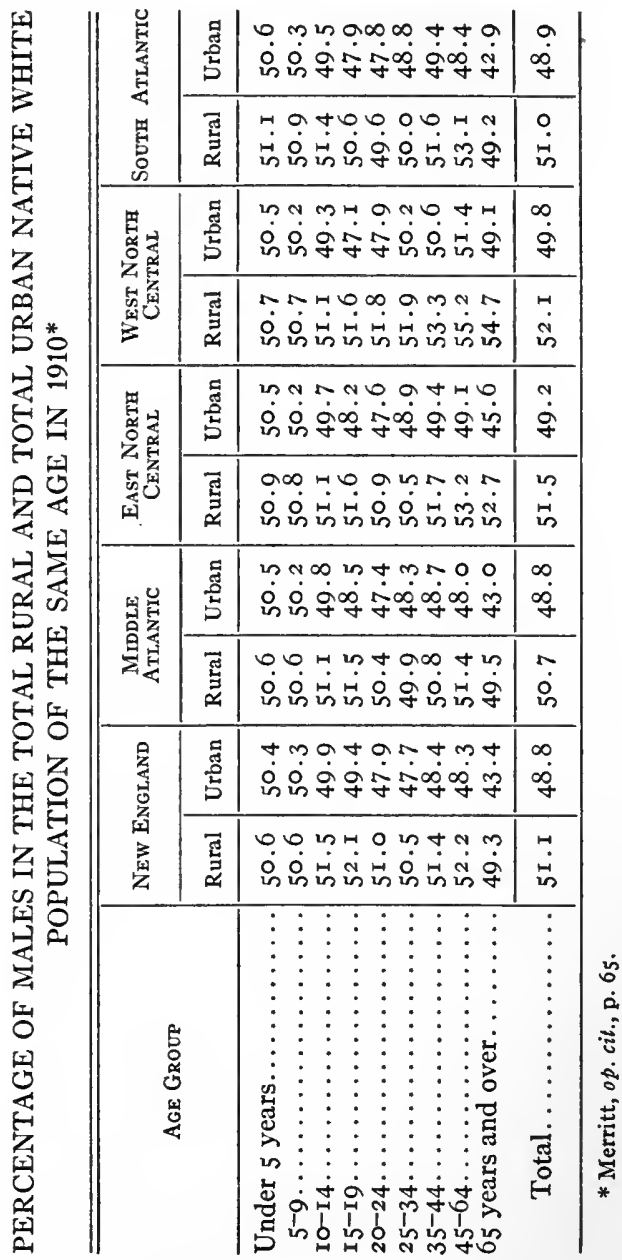




\begin{tabular}{|c|c|c|c|}
\hline 象 & 苋 & 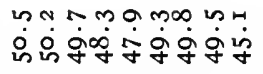 & $\dot{q}$ \\
\hline 垉 & 茪 & 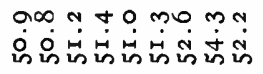 & in \\
\hline \multirow{2}{*}{ 䓵 } & 咅 & 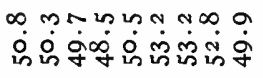 & in \\
\hline & 苞 & 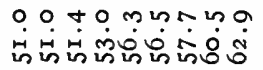 & $\ddot{n}$ \\
\hline \multirow{2}{*}{ 总 } & 蛋 & 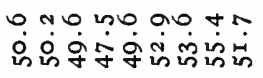 & in \\
\hline & 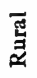 & 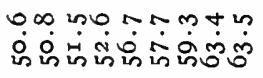 & in \\
\hline \multirow{2}{*}{ 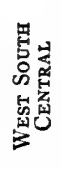 } & 总 & 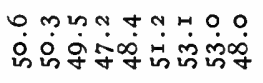 & $\stackrel{0}{\circ}$ \\
\hline & 鄫 & 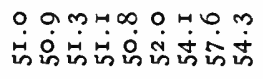 & พั่ \\
\hline \multirow{2}{*}{ 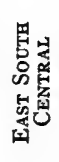 } & 总 & 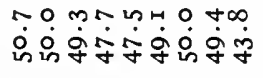 & $\ddot{g}$ \\
\hline & 焉 & 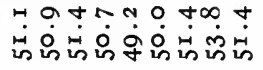 & 萑 \\
\hline \multicolumn{2}{|c|}{$\begin{array}{l} \\
5 \\
5 \\
0 \\
0 \\
0 \\
0 \\
9010 \\
4\end{array}$} & 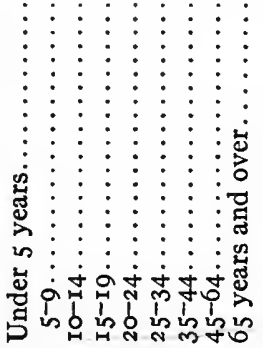 & 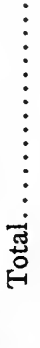 \\
\hline
\end{tabular}


the more thoughtful people of these communities felt that the standards of social life were gradually falling. As a result of this investigation and from knowledge of conditions in certain rural sections of the Middle West, Professor Ross paints a rather gloomy picture of country conditions in the two rural sections. ${ }^{x}$ It is difficult of course to determine the value of the opinion of even the most thoughtful of rural people regarding social deterioration or progress in their own communities. A chronic attitude of complaining is often to be found among the inhabitants of the long-settled rural districts, and their fault-finding stands in sharpest contrast with the discounting of urban imperfections on the part of the average city dweller and with the blind optimism or dishonest town-booming to be found in pioneering communities of the far West. This peculiar expression of community pessimism in the long-settled rural sections, significant as it may be in itself as a social phenomenon, is of little value in determining the social progress or degeneration of any locality. It is certainly easy to demonstrate that the past is generally painted in too rosy a light; it is frequently also true that the present does not receive justice. In comforts, morality, educational opportunities, and public idealism without question many rural New England communities are

I "Folk Depletion as a Cause of Rural Decline," Publications of the American Sociological Society, Vol. XI, pp. 2I-30. 
now better off than they were in the past in spite of a decrease of population. In other sections undoubtedly there has been degeneration as well as a lessening of the population. In each of these communities the character of the social life depends largely upon who goes and who stays. There are also innumerable other factors that influence the social life of a dwindling New England community. If summer visitors come to the community their character affects in a significant way the social life of the locality. Another important influence upon the community life is the interest or indifference of former inhabitants who have become successful in the city. The economic opportunities as determined by soil, distance to markets, and possibilities of co-operation, available capital, etc., are of course factors of the greatest importance.

That some communities in the oldest agricultural sections of the country deserve the following description given by Professor Ross is not open to reasonable discussion:

The continual departure of young people who would in time have become leaders results eventually in a visible moral decline of the community. The roads are neglected, which means less social intercourse and a smaller turnout to school and church and public events. School buildings and grounds deteriorate, and the false idea takes root that it pays to hire the cheaper teacher. The church gets into a rut, fails to start up the social and recreative activities which bind the young people to it, and presently ceases to

$$
43932
$$


be a force. Frivolity engrosses the young because no one organizes singing schools, literary societies, or debating clubs. Presently a generation has grown up that has missed the uplifting and refining influence of these communal institutions. There is a marked decline in standards of individual and family morality. Many couples become too self-centered to be willing to rear children. It is noticed that people are not up to the level of their forefathers, that they are coarser in their tastes and care less for higher things. Vice and sensuality are not so restrained as of yore. The false opinion goes abroad that the community is "degenerate" and therefore past redemption. ${ }^{\mathrm{I}}$

A social loss must in time be felt seriously by any community that is constantly drained of its potential leadership. Those who would have been good leaders in the community go elsewhere. In time the community becomes almost destitute of leaders. More often, however, there results a noticeable decline in the quality of the leadership material that remains. The few that direct public interests are small men and women, trivial in their interests, without vision and jealous of any attempt on the part of "intruders" to bring into the community life new standards and new ideas. If such communities were willing to support efforts for their redemption in many cases this reformation could in time be brought about. But too frequently their energy is largely used in complaining

I Ross, "Folk Depletion as a Cause of Rural Decline," Publications of the American Sociological Society, Vol. XI, p. 27. . 
of the present and pining for the past or in deadly family or political feuds.

There is a common and erroneous assumption that the rural migration always represents the departure of the best youth of the community. This is not necessarily true. Some go from country to town or city, who, however successful from urban standards, are no asset to rural life. Born, perhaps, with the gift of commercial exploitation, they leave the farm which they would never willingly have worked by the sweat of their own brows and enter urban business. The fortune or reputation they win in the city does not by any means measure the size of the loss their place of birth has suffered by their departure. In cases not a few the community has been saved from a mortgage profiteer, or a socially demoralizing storekeeper, or an unwholesome rural politician. It must be remembered also that the city has attraction for ne'er-do-wells, and for the young that love dissipation, idleness, and crime. From some communities we find that the best and the worst of the young people go to the cities. From others the migration is fairly representative of the highest, the lowest, and the average of the population.

The loss of population of greatest social concern is composed of those young men and women who are well fitted for successful and happy careers in an agricultural community. Physically, mor- 
ally, or socially they frequently suffer from living in an environment for which they are not naturally prepared. It is these young people in each country locality that furnish the promise of rural progress, and to have them departing in large number from any rural community is a social misfortune. It is this group of persons that needs to be encouraged to remain on the farm, and all the effort looking toward the conservation of rural population must be concentrated upon producing in the country such economic and social conditions as will provide for young men and women fitted for life in the country ppportunities that will make it reasonable for them to remain in the environment in accord with their deepest inclinations.

With the development of modern industrialism in the United States a relative decline in the rural population was inevitable. The cities grew by leaps and bounds under the stimulus of new economic opportunities, and a considerable part of their population increase necessarily had to come from the country. The commercial advantages of a city career were to many persons born in the country beyond comparison with any success they could obtain in a strictly agricultural environment. The social satisfactions of an urban culture also drew many from the country who from a mere economic viewpoint would have been at least as prosperous in the country as they became in the city. The 
modern order with its vast and various forms of manufacturing, transportation, and trade could not be developed without disturbing the rural structure which had preceded. Rural migration, therefore, in a great degree is the necessary accompaniment of modern industry.

The greater efficiency of farm labor due to the increasing use of machinery without question also influenced the migration from the rural sections to the towns and cities. A smaller number of persons was needed on the farm, and more could leave the country without any loss to production. It is also true that the machinery is in part the result of the scarcity of farm help rather than the cause of it, and in many instances without doubt even with the assistance of more mechanical advantages the farmer suffers from inadequate help and the quantity of production is decreased.

Neither a purely agricultural nor an industrial culture is socially for the best advantage of the nation. It is desirable rather that both country and city prosper, and that their welfare be based upon a recognized interrelation of interests. The modern population problem is neither rural nor urban but that of keeping city and country people at a high stage of culture and in a complementary occupational relationship. Even though, over long stretches of time, undue development of urban industry may tend to draw people back to the 
country on account of economic pressure, it does not follow that the two major lines of occupation will usually be advantageously balanced. Food prices are influenced by world-conditions rather than by the demands of any particular nation, and any country may become more urban than is best for its political and social interests and still obtain the necessary food supply from other countries which in turn may suffer from being almost entirely agricultural.

\section{REFERENCES ON CITY DRIFT}

Chapin, F. S., "Immigration as a Source of Urban Increase," Quarterly Publications of the American Statistical Association, September, rgr4.

Clark, E., "Contributions to Urban Growth," Quarterly Publications of the American Statistical Association, September, I9I 5 .

Dickerman, G. S., "The Drift to the Cities," Atlantic Monthly, I913, pp. 349-53.

Gillette, J. M., Constructive Rural Sociology, chap. v. Sturgis \& Walton, I9I6.

"A Study in Social Dynamics: A Statistical Determination of the Rate of Natural Increase and of the Factors Accounting for the Increase of Population in the United States," Quarterly Publications of the American Statistical Association, December, I916.

Hart, H. N., Selective Migration as a Factor in Child Welfare in the United States. University of Iowa Studies, Iowa City, I921.

Hayes, E. C., Introduction to the Study of Sociology, chap. iv. New York: Appleton, I9I5. 
Jefferson, M., "A Hopeful View of the Urban Problem," Atlantic Monthly, I913, pp. 353-58.

MacDougall, J., Rural Life in Canada, chaps. i, ii. Toronto: Westminster Co., Igr3.

Merritt, E., "The Agricultural Elements in the Population," Quarterly Publications of the American Statistical Association, March, I9r6.

Park, R. E., "The City: Suggestions for the Investigation of Human Behavior in the City Environment," American Journal of Sociology, March, I9I5.

Park, R. E., and Burgess, E. W., Introduction to the Science of Sociology, pp. 305-I5. Chicago: University of Chicago Press, I921.

Ripley, W. Z., The Races of Europe, chap. xx. New York: Appleton, I899.

Ross, E. A., "Folk Depletion as a Cause of Rural Decline," Publications of the American Sociological Society, XI, $2 \mathrm{I}-30$.

- Principles of Sociology, chap. ii. New York: Century Co., I920. 


\section{COUNTRY LIFE AND THE HERD INSTINCT}

The city drift of civilized peoples is now so universal and so apparent that it is generally recognized as one of the basic facts of modern social life. Such a persistent current of population-flow challenges the attention of the social psychologist as well as that of the economist. It is clear that the urban environment by the mere fact of its density of population captivates a multitude of people who demand satisfactions that the country with its scattered inhabitants cannot provide. Any investigation of the motives that bring country people to the city or keep them there will reveal the force of the social appeal of the urban environment. Men and women who are without work will cling to the city in most cases even when offered employment at good wages in the country. Others under stress of circumstances will accept work in the country only to find after a brief period that they cannot endure an environment which seems so empty of interests and void of pleasures.

The following incident illustrates this attitude of mind: Governor Eberhart of Minnesota tells of a visit he made to Minneapolis, in a harvest

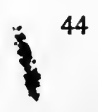


emergency, for laborers to gather wheat. ${ }^{I}$ The farmers were at their wits' ends to save their crops. It was said that the city was full of the unemployed who were looking for jobs. He found them, as he says, seated on the park benches in all sections of the city and overflowing to the curbstones. Work, it seems, could not be found. Some of the men were on the verge of starvation, and the charitable organizations of the city were taxed to their utmost capacity to provide for them. It looked as if his task would be an easy one and he could take back as many men as he wished. He picked out his men and told them he wanted their help. They were eager for the chance and said they could do anything. He spoke of the service he had in mind, in the country and on the farms, when instantly their faces fell and they were as glum as they had been before. Their answer was: "We don't want to go to the country, boss. We don't want to live on a farm. There's nothin' for us there-no life, no entertainment, no lights-nothin' but monotony and work. We'd rather stay in the city and starve than go to the country and have nothin' to do but work. No, sir, we stay right here." And stay they did. He couldn't get one of them to go with him. The farmers had to harvest their wheat as best they could while the city held in its grasp, unemployed, enough men to garner all the crops of the state.

${ }^{1}$ Atlantic Monthly, September, 19I3, p. 35 r. 
The psychological causes of city drift are socially most sinister. They are insensible to conditions that tend by the operation of economic law to provide a reasonable balance between rural and urban population, and thus they may draw people to the city in opposition to the welfare of the nation or the individual.

Any analysis of the psychic causes of rural migration exposes the significance of the gregarious impulse. This desire to be with the herd greatly influences both the animal and man. Perhaps the unwillingness to be cut off from the group association, commonly called the gregarious instinct, can be still further analyzed and reduced to simpler elements, but, as Watson suggests, the gregarious behavior is so characteristic both of animals and of man that a more complete analysis seems out of place. ${ }^{\mathrm{I}}$ By grouping the activities resulting from the impulse to associate with the herd under the term gregarious instinct justice is done to the inherent craving for group contact which occupies so prominent a place in most animal and human activities.

The individual is impelled to be with and of the herd. Any separation from the group means restlessness, and as seen in the case of solitary confinement may become an insufferable punish-

${ }^{x}$ Watson, Psychology from the Standpoint of a Behaviorist, p. 258 . 
ment. The evolutionary purpose of the gregarious impulse was without doubt protection of the individual. The animal outside a herd increased his danger and decreased his protection. While he kept within the herd he enjoyed the protective resources of the group as a whole. It is not strange that so useful an attitude for the animal in his struggle for survival came to have such a determining control over the behavior of most animals. The significance of the gregarious instinct in biological history, science is just beginning adequately to recognize. It has remained for Trotter to show how prominent and how important the gregarious conduct is in the social life of the animal and of man:

A study of bees and ants shows at once how fundamental the importance of gregariousness may become. The individual in such communities is completely incapable, often physically, of existing apart from the community, and this fact at once gives rise to the suspicion that even in communities less closely knit than those of the ant and the bee, the individual may in fact be more dependent on communal life than appears at first sight.

Another very striking piece of general evidence of the significance of gregariousness as no mere late acquirement is the remarkable coincidence of its occurrence with that of exceptional grades of intelligence or the possibility of very complex reactions to environment. It can scarcely be regarded as an unmeaning accident that the dog, the horse, the ape, the elephant, and man are all social animals. The instances of the bee and the ant are perhaps the most 
amazing. Here the advantages of gregariousness seem actually to outweigh the most prodigious differences of structure, and we find a condition which is often thought of as a mere habit, capable of enabling the insect nervous system to compete in the complexity of its power of adaptation with that of the higher vertebrates. ${ }^{\mathrm{I}}$

In human society there is in every environment evidence of the working of the gregarious instinct. The urban environment, however, provides the most favorable circumstances for the satisfaction of the gregarious desires. In a multiplicity of forms the gregarious impulse is awakened and satisfied. This fact certainly throws light upon the rapid growth of cities and even suggests that one prominent cause of the migration of country people to the cities is the psychic urge of the gregarious instinct. This is the psychological interpretation of our present city drift given by McDougall. He writes:

It is sometimes assumed that the monstrous and disastrous growth of London and of other large towns is the result of some obscure economic necessity. But, as a matter of fact, London and many other large towns have for a long time past far exceeded the proportions that conduce to economic efficiency and healthy social life, just as the vast herds of bison, or other animals referred to in chapter ii, greatly exceed the size necessary for mutual defence. We are often told that the dulness of the country drives the people to the towns. But that statement inverts 19-20.

I W. Trotter, Instincts of the Herd in Peace and War, pp. 
the truth. It is the crowd in the towns, the vast human herd, that exerts a baneful attraction on those outside it. People have lived in the country for hundreds of generations without finding it dull. It is only the existence of the crowded towns that creates by contrast the dulness of the country. As in the case of the animals, the larger the aggregation the greater is its power of attraction; hence, in spite of high rents, high rates, dirt, disease, congestion of traffic, ugliness, squalor, and sooty air, the large towns continue to grow at an increasing rate, while the small towns diminish and the country villages are threatened with extinction.

That this herding in the towns is not due to any economic necessities of our industrial organization, is shown by the fact that it takes place to an equally great and regrettable extent in countries where the industrial conditions are very different. In Australia, where everything favors an agricultural or pastoral mode of life, half the population of a continent is crowded into a few towns on the coast. In China, where industry persists almost entirely in the form of handicrafts and where economic conditions are extremely different from our own, we find towns like Canton containing three million inhabitants crowded together even more densely than in London and under conditions no less repulsive.

In England we must attribute this tendency chiefly to the fact that the spread of elementary education and the freer intercourse between the people of the different parts of the country have broken down the bonds of custom which formerly kept each man to the place and calling of his forefathers; for custom, the great conservative force of society, the great controller of individual impulses, being weakened, the deep-seated instincts, especially the gregarious instinct, have found their opportunity to deter- 
mine the choices of men. Other causes have, of course, co-operated and have facilitated the aggregations of population; but without the instinctive basis they would probably have produced only slight effects of this kind. ${ }^{x}$

The imperious influence of the gregarious instinct in developing and enforcing group solidarity came out clearly in the recent world-war. At the cantonment, where human individualism was hammered into the soldier-mold, where the raw recruit started training, the herd instinct was dominant in every department of the men's life. Anyone who visited an army cantonment must have sensed the gregarious atmosphere of army service. For a few men this was the most trying experience connected with the service. Others found in it the supreme satisfaction. Every soldier was influenced by it more or less. What did it mean to the soldier who had come into the army from the small country place? We know, as a result of what social workers among the soldiers tell us, that the country boy was often very sensitive to this enormous change from an isolated neighborhood to the closest contact possible, in a community which was literally a real city. By necessity men from the country were forced into the conditions of city life, into an environment that was more gregarious than any normal urban center experiences. What result did this have upon the social

${ }^{5}$ McDougall, An Introduction to Social Psychology, pp. 3०3-4. 
needs of the men from the rural districts? It was to be expected that many of them would not be content again in the country. They developed cravings that the country-life environment cannot satisfy. For this reason it is not likely that the placing of former soldiers and sailors on the land will have in any country the success desired. Much will depend upon who is selected to go into the country. On the other hand, this war has added to the city drift of our population and increased the number of those who form the mobile class of rural laborers.

Although modern invention has created circumstances of life that make possible more comfortable living conditions outside great cities than ever have been possible in the past, the mass of people have been turned from the individual satisfactions made available and have sought with the greatest intensity gregarious pleasures. Men and women as never before wish to feel the zest of herd joys; in both work and play they detest isolation. The city street with its crowds becomes a source of pleasurable sensations that can hardly be had elsewhere. The gregarious satisfactions furnished by the urban environment captivate the senses quickly and increase their tyranny with the passing of time. Country-bred men and women have been known to become so saturated with herd cravings in a few short months as to find even a short visit to their 
parents' country home unendurable, and in spite of genuine affection they have sought in vain to control an intense restlessness for familiar gregarious experiences. The old community seems literally a dead thing; a social situation without density of population lacks meaning and animation. The present trend appears to be toward a self-chosen enslavement of the mass of people as a result of an unreasonable emphasis upon gregarious satisfac-

z tions. Public thinking and public activity were never more influenced by gregarious impulses. Nearly every type of propaganda originates in the city and is directed from it. The city thinking which assumes national dictatorship is permeated with gregarious superstition and concerns itself with gregarious gossip and trivialities. A street occurrence of little or no significance to the passerby will quickly gather a crowd and hold a busy merchant on an important mission even when he has no chance of satisfying his gregarious curiosity. The urban-manipulated fashion due to the gregarious servitude readily accepted by the majority of city dwellers grips an entire territory with no regard to comfort, health, or aesthetics.

The gregarious instinct of man has been greatly intensified by the urban standards of life that have been popularized by the magnitude of modern industrialism. Into every country home goes today as a result of the power, prestige, and avid- 
ity of the modern city an invitation to the gratification of gregarious desires. The mail that brings contact with the neighboring city and thus provides the means of enjoying in the country some of the advantages of urban culture also calls attention to the dominance of city standards. Even the news of the day must be read in an urban setting. The city reaches into every hamlet and awakens desires that demand for their final satisfaction lifeconditions that only the town or city can provide.

Governments are unable to disregard the herd desires of the people and by their policies magnify the importance of the gregarious cravings until it becomes a politician's axiom that provision must be made for the useless and the spectacular even in times of stress if only a multitude of people may be brought into the streets to revel in the joys of closest proximity. Administrations rise and fall by their ability or inability to make a gregarious appeal. Riots become gregarious intoxication. Calm judgment is stolen by the mob, led perhaps by a mere youth, as was reported in the recent Omaha race riot, and a mass of well-meaning men and women carry out the most savage and irrational program under the spell of a gregarious debauchery.

There is just now the greatest need of a large portion of our people remaining immune to the contagious passion for gregarious experiences. 
Individualism is in danger of social extinction. Social forces, organized and manipulated with great skill, mold people into group personalities. Spiritual freedom, intellectual individuality, is being crushed by the stupid opinion of the mass, an opinion for the most part artificially formed by economic or intellectual exploiters. In the country are to be found the favorable conditions for individualism, and statesmanship that has vision will endeavor to protect it that our political and social policies may be determined in part by influences that are not excessively gregarious.

The gregarious instinct does not merely tend to draw men and women into association; it also produces psychic sensitiveness to the suggestions arising from the herd. The individual is uneasy unless he can enjoy the sense of oneness with the group. The gregarious impulse is not content merely with drawing the individual into a social group. It also operates upon the psychic life and builds up a state of mind which is known as suggestibility. The city crowd gives us a perfect illustration of a gregarious collection of persons and the resulting condition of a highly developed suggestibility. Suggestion, although rooted in the gregarious impulse, is not limited to contact in the large group. Whatever association there may happen to be will afford an opportunity for the mind states of his fellows to penetrate the psychic life 
of the individual and thus bring him under the sway of suggestion to the degree that he is sensitive to other mental attitudes.

An analysis of the psychological aspects of city drift necessarily includes suggestion. Suggestion may be defined as "an indirect appeal which awakens a determining tendency in such a way that the subject has more the sense of acting on his own initiative than of responding to external influence." ${ }^{\prime}$ Recent psychological discoveries have given emphasis to the large part suggestion plays in the careers of men and women, especially when it is allied with the results of early childhood impressions. As psychology advances toward a causal understanding of human conduct, more and more it reveals the commanding influence that belongs to the impressions of childhood and early youth. It is increasingly clear that many of the happenings of adult life can be explained only when they are brought into relation with the events of childhood.

Early experiences that prepare the way for the later influence of suggestion upon adult decisions contribute their share of the causes of rural migration. Country-life conditions have given in the past the suggestion to many young men and women that farming is an occupation of exceptional toil.

× Gault, "Suggestion and Suggestibility," American Journal of Sociology, September, igig. 
This fact is often revealed by the statements of city people who were brought up on a farm. It is one of the most common reasons given for the leaving of the farm life, and even if it may not be the chief reason for the removal to the city as often as is affirmed, it surely plays a significant rôle in rural migration. These suggestions that farming has excessive need of toil are often gathered from the remarks of parents and older people in the presence of children. Discouraged and discontented fathers and mothers who dwell on the hardships of country life originate suggestions that influence some of the young people who leave the country for the town and city. These criticisms of farming and of country community conditions are not uncommon among country people, and children who often hear them can hardly fail to develop antagonism to the country environment. Farming is the only occupation where dissatisfaction with the results of one's labor easily passes into an attack upon the environment itself. The farmer cannot change his occupation as a rule without moving to a radically different environment. Personal disappointments and dissatisfactions in this fashion are apt finally to color his attitude toward the country environment itself.

A small matter that may at times lead to deepset dislike of the country is the grievance the schoolboy feels when his plans for a holiday are interfered 
with by the necessity of his helping his father on the farm. This experience, although trivial to the adult, may linger long in the mind of a child and alienate him from country-life interests.

Education in all its forms is ever in danger in the country of giving the growing boy and girl urban ambitions and urban ideals. Until recently the content of study in country schools insidiously underminded the natural attractions of the country. The urban viewpoint was both consciously and unconsciously emphasized by the teacher, who was generally ill prepared to interpret the value of country interests to the children, and who was herself often dissatisfied with the conditions of life in the country. As has long been recognized, the preacher also frequently brought to the young people of his church urban attitudes and urban cravings that added to the appeal of the cities and thus encouraged city drift. If 'these suggestions from teachers and minister induced the boy and girl most fitted for urban life to leave home for a proper field of activity, it is also true that the same influence sent to the city others who naturally would have remained on the farm and prospered.

Considerable progress during the last decade has been made in the correction of this urbanizing influence of the public schools of the country. Teachers have been prepared to appreciate country-life values and have become sympathetic toward the 
opportunities of the open country. Preachers also have become conscious of the danger of the "urban mind " and in many cases have acted as interpreters to country people of the resources and satisfactions of rural life. However, there are still teachers in country schools and preachers in country churches who have their faces set toward the city, and whose influence necessarily reinforces the movement of the country population to the cities.

The urban advantage in social prestige has influenced rural people through suggestion and has added another motive for moving to the city. The city furnishes the conditions for political and commercial distinction and for the accumulation of great wealth. Production by machinery affords opportunity for administrative ability and technical skill, and the executive and the artisan are the best paid in their respective classes. These representatives of modern industry by their large earnings set the standard for brain and hand work, and both of them flourish only in the urban environment. Unconsciously these two classes are accepted as typical illustrations of the advantages of urban opportunity, for the standard of life of the unskilled laborers in the cities has never succeeded in offsetting the prestige created by the spectacular wealth of the man of "big business" or by the high wages of the skilled worker. The rural occupation, on the other hand, has never 
received a just social appreciation. Unfortunately, farming permits a man with little ability, shiftless in his habits and lacking energy, somehow to exist on a low standard of life, and this type in the country has attracted greater attention than he deserves and has given farming less prestige as an occupation than belongs to it. The hazardous character of farming, the effect of season and natural conditions that cannot wholly be anticipated even by the most efficient of farmers, makes it impossible for the intelligent farmer to demonstrate the full measure of his superiority. Thus rural efficiency never gets all the social recognition to which it is entitled.

The complete force of urban suggestion along lines of occupational prestige cannot be revealed until it is frankly admitted how much of late social thinking has discounted manual labor. This fact is especially disclosed by the increasing difficulty of getting women to hire out to do housework even when the economic returns offered are greater than they can obtain in the other occupations open to them. In somewhat the same way, but fortunately in less degree, there has grown up in the social mind an estimation of occupational desirability which has placed the professions and even clerking above farming. Perhaps the need of wearing "working clothes" when farming has had something to do with this creation of false occupational color. 
Its superior community resources have also given the city a prestige which enters country thinking and suggests the inferiority of the rural environment. The city is accepted as the community standard merely because the gathering of population into narrow limits makes possible a vast number of social enterprises.

The superiority of the city is by no means accepted by all country people. Many react to the suggestion negatively; the evils of the urban environment are given excessive emphasis. Psychologically, however, this hostility to the city civilization often reveals the deeply felt force of urban dominance which is resented but which nevertheless is not without influence.

A profound psychological cause of city drift is the increasing modern appetite for exciting sense stimulation. This craving is more significant than that which springs from any instinct, for it represents the original need of the mind. Consciousness demands stimulation, for only so can it function and fulfil its biological destiny. It is the business of mind to attend. By its activities in response to stimuli from the environment the mind both gathers knowledge and obtains inward satisfactions.

The present craving among occidental peoples for intense quantitative sense experiences is of course no new human experience. The new element in the situation consists of the forms it takes 
as a result of the wonderful opportunities for violent stimulation made possible by applied science. The intensity, the variety, and the accessibility of myriad forms of exciting stimulation, artificially created by modern industry, constitute a new order of human experience. The new opportunities bring forth new needs until there results an unparalleled appetite for stimulation of quantitative character. Much of the labor and much of the wealth of this age are consumed in feeding this world-wide hunger for intense, artificial sense experience. Science has developed more rapidly than has man's appreciation of the best uses of its enormous resources.

It is only the city, however, that can furnish the necessary conditions for the largest amount of this type of quantitative sense experience. The country by contrast seems to those who have once tasted with satisfaction urban intensities a dull place with little that invigorates the mind. People in the city crowd together not merely because they are gregarious. The close contact, the massing of persons, also makes possible a multitude of quantitative sense pleasures that can by no means be duplicated in the country. The country may more and more obtain the advantages of modern invention, but its meager population forbids its ever competing at this point favorably with the city. It must lag behind in its ability to supply 
exciting experiences on a scale easily provided by urban environment. It has a handicap imposed by the inherent limitations of rural life and in this age a handicap of large social significance.

The appeal of city pleasures goes out to rural people. By word of mouth, by the daily press, by commercial propaganda, through advertising, the attractions of the city along all lines of quantitative sense experiences are brought to the notice of country people. The force of this in turning many toward the cities is not likely to be over-estimated.

We have no reason to suppose that the appeal of quantitative stimulation will have less influence over the next generation. The opposite seems liable to prove true. The precocious introduction given most children to the exciting pleasures of the moving picture, the automobile, and other recent additions to society's equipment for quantitative experiences will surely create in them an appetite more exacting than that of their parents for conditions of life that necessarily can be had only in the cities. The next decade, unless in some way there can come a reaction against present tendencies, is destined to see urban life adding to its social attractiveness and rural isolation becoming more and more oppressive for an increasing number of people.

The rural environment is by no means destitute of fascinating sense stimuli. It naturally abounds 
in interests. All it requires is capacity for appreciation. The tasks of farming may be either pure toil or achievement. The decision is determined by the attitude of the worker. Farming is really less monotonous than the work of most city dwellers; it can be carried on with a zest difficult to duplicate in most urban employment. The great stretches of land also may seem either dreary spaces, mere fields of corn or wheat, or territory filled with meaning. Everything depends upon the interpreter. The country environment has an unquestioned supremacy in poetry, freedom, and closeness to nature, and ingenuity. It is the spirit of the age that is robbing it of much of its attractiveness.

The antidote is better education. In the cities and in the country there is need of educational reconstruction. Instruction must have more social purpose, more social motive. It must loosen the artificial grip that commerce now has over the desires of people everywhere. Our wants are largely made for us by the standards put upon us by clever suggestion. Education has largely ceased to influence the purposes of life; it is content merely to furnish tools. We are taught to read by the schools, but what we read in the schools has very little significance for our manner of life. Human wants, however, need not be so exclusively material as in recent years they have been. 
Indeed, the reaction against the tyranny that quantitative stimulation has been exercising, largely because of our social immaturity, has already appeared. Our present industrial discontent contains suggestions of a demand for a democratic culture. There is reason to suppose that sooner or later good taste will become more popular. When public opinion is equal to the discrimination required to make use of modern machinery without crushing social sanity there will surely come a reconstruction of human pleasures and human demands. This reform, which the very stability of society requires, will restore to the rural environment in reasonable degree its peculiar and wholesome appeal.

Rural education, in addition to its greater socialization, must become more capable. Life in the country need not be meager nor hard. Invention furnishes country people with the great majority of really important mechanical resources. Education that can reveal to men and women in the country the things in their life of real worth will enable the majority of country people to enjoy their environment and not hanker after the peculiar experiences possible only in great cities. In other words, country people may discover how to appreciate their own conditions while sharing, as their fathers could not, a great many of the advantages of city society. Even when the country environ- 
ment is interpreted to its utmost rural people will not in great numbers endure psychic isolation. City contacts will be maintained and multiplied. Even the crossroads grocer is now in peril because so much of rural trade goes into the city. It is the crude gregarious appeal, the mere love of crowded streets, not city contact but city herd life, that steals the values of country-life environment. Rural education in all its forms, for children and for adults, needs more efficiency in helping country people adapt themselves happily to their surroundings, but it must not antagonize urban and rural contact. If living in the country comes to mean merely thinking in neighborhood terms, we can populate the country districts only by creating a dull American peasant class.

\section{REFERENCES ON COUNTRY LIFE AND THE HERD INSTINCT}

Cities Committee of the Sociological Society. "A Rustic View of War and Peace," Papers for the Present, Third Series, No. 8. London: Headley Bros.

Edman, I., Human Traits and Their Social Significance, chap. v. Boston: Houghton Mifflin Co., I920.

Groves, E. R., Rural Problems of Today, chap. ix. New York: Association Press, I918.

- "The Urban Complex," Sociological Review, autumn, I920.

McDougall, W., An Introduction to Social Psychology, chap. xii. Boston: Luce \& Co., 1918. 
Tansley, A. G., The New Psychology and Its Relation to Life, chaps. xix, xx. London: Allen \& Unwin, 1920. Tead, O., Instincts in Industry, chap. viii. Boston: Houghton Mifflin Co., I9r8.

Trotter, W., Instincts of the Herd in Peace and War. New York: Macmillan, i9i 7. 


\section{V}

\section{THE INSTINCT OF SELF-ASSERTION}

The instinct of self-assertion is one of the most powerful and important of all the instincts that influence man's social behavior. Although the instinct appears to emphasize the individual in contrast with others, it nevertheless demands a social background. The group is present as the field of self-assertion, for obviously one cannot assert himself except in association with other persons. The instinct of self-assertion expresses itself in varied forms. For example, we have the positive and negative attitudes of self-assertion. Both attitudes attempt to magnify the individual and attract attention from his fellows. In the one case attention is sought by aggressive activities, and in the other by an assumption of meekness or self-abasement, which attempts to accentuate the individual in contrast with his associates.

Self-assertion has been thoroughly imbedded in human nature by the processes of selection and survival. Any individual or racial deficiency in this instinct in evolutionary history has surely been a very great handicap. Modern man represents a line of descent which has so thoroughly established the instinct of self-assertion that no 
normal individual is destitute of it. Indeed it occupies so large a place in the average life that modern society constantly tries to control and prevent its excessive expression. From the earliest years of childhood to some extent every developing life comes in contact with influences that deliberately aim to lessen and socialize selfassertion. A large part of the practical difficulties of child-training centers about this process of teaching the individual to suppress, at least so far as outside evidence is concerned, the powerful impulses that he feels of self-assertive character.

The difficulty of forcing self-assertion to keep within bounds is revealed by the experience of the neurotic. Recent psychology, especially psychoanalytic psychology, bears testimony to the innumerable evils that arise in the process of limiting self-assertion. Unhappy obstacles to reasonable self-assertive satisfaction operating in early childhood may create cravings for power which appear in adult life without hope of attainment. The individual goes through life hungering for selfassertive satisfactions that for one reason or other are denied him. On the other hand easy success in the early years or exaggeration of one's importance as a result of foolish pampering and flattery on the part of parents may build up a selfestimation which cannot withstand the shock of adult disenchantment. The individual under such 
conditions frequently is unable to meet reality and escapes from the difficulty of accepting a correct estimation of self by the development of a neurotic disorder. Thus he finds satisfaction for his selfassertion without any limitation. He enters the world of magic. He creates pleasing circumstances and struts in the fictitious world which he has made as his refuge from the bitter facts of life. As Adler has pointed out in his important contribution to psychoanalytic psychology, self-assertion may operate in two ways in the reactions of the individual to his handicaps and limitations. If self-assertion has momentum enough to push the individual through his difficulty, he comes forth with increased power and self-confidence. By thus attaining the masculine protest against obstacles, he gives his self-assertive tendency an outlet which promises a large use of the individual's opportunities. But if the difficulties are not surmounted, and the self-assertion suffers defeat, a permanent injury may result. It may be years before the seriousness of the experience reveals itself. Sooner or later, however, the life bears witness to the tremendous significance in each individual career of any maladjustment of the instinct of self-assertion. A nervous malady may appear which had its origin in the crushing of the cravings for power experienced way back in childhood. 
Self-assertion has played a large part in social evolution. From the beginning one of the motives which led men to more complex and stable forms of social organization was the desire of the masterful persons in places of authority for increased power. The family patriarch easily developed into the clan leader; the tribal warrior naturally became the king; the king and his counselors seldom escaped the appetite for more prestige, greater territory, more authority, larger recognition. Out of the clash of political rivalry and the competition of assertive men much of social progress got its impulse. Social changes have never eliminated this striving for power on the part of those who have forced themselves to the front, but fortunately the form of the struggle has from time to time changed under the influence of social opinion.

In the urban environment it is easy to see the large place that self-assertion holds. Competition in the modern world is another word for the conflict between persons who under the impulse of selfassertion find themselves clashing as to personal interests. No characteristic of the city stands out more clearly as the very atmosphere of the life of the people than does competition. It appears in every form. It is present in industry, in trade, in sport, in cultural rivalry, in class organizations, and in politics. There is no city dweller but finds himself drawn into some highly competitive rela- 
tionship. Even the criminal gets part of his zest from the satisfaction it brings him to match his wits against those of the guardians of property and order.

Naturally the city acts as a magnet in attracting into its life and holding within itself those who especially enjoy the competitive struggle. The influence of the city at this point stretches over a wide territory and invites the highly assertive country and village youth in his early ambitious years to try his fortune in the urban setting where conditions are more to his liking. Merely by bringing together such an enormous number of persons particularly self-assertive, the city wins for itself social leadership, prestige, and increasing power. Its reputation still more advertises its competitive opportunities and adds increasingly to the migration of persons who cannot find a reasonable field for their self-assertive needs in the rural or village environment.

Man does not merely go to the city and express the self-assertion already developed. Whatever his degree of self-assertiveness, originally, the instinct is stimulated to still further growth by city influences. He who enters the urban environment from the country or village probably is most sensitive to the stimulating competition of his new environment. The city man does not escape the same influence. Every ambitious person re- 
sponds to the constant and permeating atmosphere. The suggestions that call forth the aggressiveness of the individual are often unconscious, but they are for that reason not at all weaker. Only those who have given up the struggle and who feel themselves victims in the ever-present contest fail to respond to the urban stimulations. Thus the city is a training-school for the utmost development of the self-seeking instincts. One cannot, however, appreciate the full significance of urban competition if he thinks of it only as a contest between persons. The very nature of the struggle forces individuals to group themselves for mutual protection, and a great part of city competition is between groups and classes and organizations. The more complex our civilization becomes, the more highly organized and the more self-conscious many of these groups become. Any attempt to understand the thinking of city people must take into account the large place group consciousness holds in the make-up of the individual. More and more one is forced to think in terms of the group. Class consciousness deepens and becomes more vigorous. One feels himself drawing closer to those who are allied with him in common interests while at the same time a greater gulf divides him from those with whom he is in struggle. Everything conspires to bring forth the spirit of competition. A large part of this aggressiveness is fundamentally 
for the purpose of self-protection. One attacks the opponent that he may not himself be placed in a position of weakness. The aggressive attitude becomes a method of class strategy. The city is filled to overflowing with innumerable movements, all directed by aggression originating from a variety of sources. The individual, as he moves about in his daily work, his recreation, his habitual associations, imbibes from every quarter suggestions that he contribute as far as possible to the particular aggressions that win his sympathy. Doubtless this is one of the most fascinating elements in urban life, and it is reasonable to suppose that men and women who love struggle, who covet self-assertion, whether it be expressed in individual or group form, will find the city increasingly satisfactory, and the country place an impossible environment.

At this point we need to notice that a great part of personal aggression obtains its satisfaction by identifying itself with the masterful personalities who lead in the several groups and organizations. The gregarious leader who wins in any movement a place of authority and influence, by his very successes wins the admiration of those who cannot in the same degree satisfy their personal ambitions, but who do identify the successes of their chosen leader with their own unsatisfied cravings. This is largely the explanation of the partisanships and enthusiasms that flourish in the urban environment. 
To be sure, country people also can identify themselves in the same manner with group leaders, but their opportunity is relatively smaller, and they seldom have the sense of personal contact. The city man is likely to choose for this vicarious satisfaction of the aggressive instinct a hero whom he can see, and this intensifies his aggressive emotions and brings them greater satisfaction. The least harmful and the most noticeable expression of this gathers about sport, and no one who has ever witnessed the city crowd at the big game or before the bulletin board can fail to recognize the deep satisfaction that comes to those who in rivalry and competition enjoy the sense of identification. Thus the events of city life constantly minister to the deep-seated cravings for self-assertion.

It is not true, however, that the city literally strips the country of all its competitive types. Such a condition would be impossible. Even though the most ambitious migrate, some remain who are relatively more assertive than their fellows. It is also true that many are to be found in the country who are in the highest degree self-assertive, but who, for one reason or another, have never had their instincts awakened, or have not had the opportunity to change the rural environment for the urban. As a rule, however, it is safe to say that the general level of competitive activities is lowered by the movement of the most aggressive 
individuals from the country to the city. Selfassertion, therefore, has to take more trivial forms. The scale is reduced. This, of course, does not mean that the instinct occupies a less significant place in the life of the individual, but merely that the form it takes socially is qualitatively different. Here we have an explanation of some of the most unhappy occurrences of rural life. Family competition may become excessive and develop into family feuds. Differences of policy between individuals become the basis for a life-long struggle, in which each person spoils his best possibilities in a foolish contest. The social ambition of one selfseeking person collides with an equal ambition on the part of a neighbor, and both waste their resources in what to an outsider seems a senseless competition. Such happenings cannot be understood unless one sees in them the revelation of an enormous need in the rural environment for satisfactory ways of expressing self-assertion.

The villager and the countryman are often psychically estranged and develop feelings of hostility. Though this may originate in a collision of economic interests, nevertheless there is always present a certain degree of self-assertion. The farmer frequently complains of the superiority that the villager assumes. It is the self-assertive farmer who feels the injury. If the feeling of superiority is really present in the mind of the villager, it is 
rooted in the same instinct. The contact of country and village children, teachers tell us, occasionally shows the same collision of self-assertion which exists too often between the villager and the countryman.

This sense of superiority of the persons of the village is sometimes based upon the greater contact of the villager with the neighboring city. $\mathrm{He}$ prides himself upon sharing the larger cultural opportunities of the city, and puts in contrast the lesser privileges of the man of the country. The tables, however, are frequently reversed, particularly when prosperous farmers surround an industrial village where the standard of living of the villagers is much below that of the farmers of the open country. It is then that the farmers look down upon the villagers and the farmers' children assume superiority. Of course, the same instinct, selfassertion, is at work, and unfortunately to such a degree as often to forbid wholesome community life. The struggle between the village and the rural group which shows itself often in a spectacular way in the New England town meeting is not merely a contest with reference to taxation policies, but a group struggle in which class consciousness plays a very prominent part. Once the two groups are lined up on any specific proposition, reasoning is of little avail. Each wishes success because the self-assertion of the group has been awakened. 
Under such circumstances passion shows itself to a degree that cannot be explained by the signifificance of the issues at stake.

It is a happy thing that rural statesmanship in recent years has made possible so much wholesome industrial rivalry between farmers. The more dangerous competition is diluted and becomes useful rivalry. This affords for persons who have not grown excessively competitive as much satisfaction as the self-assertive instinct needs. The welfare of the country requires the utmost development of this form of competition. If the rivalry concentrates upon the product brought forth, it stimulates progress while at the same time giving an opportunity for the mild contest which human nature craves. If, however, too much attention is placed upon the element of success and too little upon the craftsmanship which brings forth the success, even this form of contest can become socially separating and form a community division most unfortunate in social results.

It is necessary that the value and also the danger of prize contests for boys and girls be kept in mind by the promoter of such enterprises. It is of the greatest importance that the country boys and girls be introduced to wholesome rivalry and learn the opportunity the country provides for distinction and competition. It is only when such contests develop an interest merely in the 
success itself - in the prize or prestige of the prize winner - that encouragement is given to influences that injure rural community development. The club leader may be so anxious for immediate and spectacular success that he may exploit the selfassertion of boys and girls for his own selfish purposes and develop a spirit of rivalry which passes into bitter hostility. In this way a movement which is supposed to unite the people of the country community and develop their social resources entirely defeats its purpose and sometimes separates family against family in such a way as to make constructive social work in that community almost impossible. It is equally true that when the boy or girl who wins the prize in the agricultural contest is given an unreasonable amount of publicity and greatly flattered, he may become so captivated by the pleasures of social distinction that soon he will find the country environment intolerable because such a tremendous degree of self-assertion has been evoked. By the contest he has been educated in competitive effort for its own sake and sooner or later he will naturally drift out of the country into the urban environment where he can exercise to the full the aggressive impulses that have been formed. Safety consists in putting the emphasis upon the activity itself. The prize winner must be led to see the meaning of the effort, that his eyes may not concentrate 
upon the prize or the victory itself. In other words, the ambition must be created to obtain still greater mastery over the processes involved. When this is done we are sure of a persistent interest in the enterprise and the danger of selfpride is necessarily eliminated.

One of the most fortunate expressions of the self-assertive instinct in the country is the friendly rivalry among adults along agricultural lines. Poultry enthusiasts attempt to bring forth the prize bird of the community; the cattle raiser becomes a partisan with reference to a breed of cattle and exhibits his pure-blooded stock. Hardly any country place is so destitute that it does not have at least two or three who are particularly interested in some sort of agricultural competition and whose hens, cattle, horses, sheep, or swine represent serious effort to maintain a reputation. This competition is important not merely because it produces a fine agricultural product, important though that is, but because it also affords wholesome expression to self-assertion. Such a fortunate will to power needs every possible encouragement. The father who early introduces his son to some such form of competition does all that can be done to give the youth a taste of one of the most satisfying pleasures of country life.

The self-assertive instinct is of greatest importance in rural organization. This especially 
appears with reference to the problem of leadership. The prosperity of rural society depends upon the character of its leaders and especially its local leaders. The leader is primarily made by his selfassertive cravings. This is particularly clear in the case of the local leader. It is his desire to find a satisfactory outlet for his natural equipment which makes him a marked man in the community. In character he does not differ in any respect from the urban leader. His environment, however, makes it necessary that his instinct express itself differently. We sometimes forget how self-assertive men may be in the rural environment without having much opportunity for self-expression. This was thoughtfully expressed by Thomas Gray in his elegy, "The Country Churchyard":

Some village Hampden, that with dauntless breast The little tyrant of his fields withstood, Some mute inglorious Milton here may rest, Some Cromwell, guiltless of his country's blood.

Any effort at rural organization is much concerned with the character of local leaders. Such persons already occupy the field and wield considerable power. Frequently they are grouped in two or more hostile divisions, making it very difficult for any organization to come into the community and build up a common program. Men who hold local office or who use their puppets whom they have placed nomiually in the positions whose 
power they actually control are in small form the same type as the city bosses. Whether they are self-seeking in the sense of the man of the street or whether they are community-spirited, the motive in either case is generally the satisfaction of selfassertion, even though their deep-seated cravings may be altogether unconscious.

While rural organization must give heed to the local leaders already in power, the future wellbeing of the country place usually rests upon the ability of the incoming organizations to develop the potential leaders. Often the persons best fitted to be useful have not been brought out. Perhaps they have been unwilling to enter the contest for power because of the unpleasant conditions of the struggle previously prevalent in the community. When, however, they are captivated by sufficient motive they reveal unexpected qualifications for leadership. Their self-assertive instinct demanded a more inviting form of expression than was afforded, for example, by local partisan politics.

Any organization working in the country finds one of its chief problems to be the education of local leadership. The men in power who are eager to continue their authority are not necessarily wholesome leaders from a community viewpoint. They may have all the qualifications of selfassertion and still lack the vision or the intelli- 
gence or the social sincerity required. Under such circumstances any community program will not be permanently established unless the leadership already in the community is given a new point of view or is supplanted by the type the occasion demands. In practice the organizer finds one of his most delicate and significant responsibilities his relation with leaders already intrenched in the community, and in his ability, when socially necessary, to get rid of them without causing a community rupture. It helps anyone who faces this problem of local leadership if he clearly appreciates the significance of the self-assertive instinct as it expresses itself in the behavior of the leaders.

The rural organization that serves the country best is that which most nearly satisfies the selfassertion of a multitude of persons. The conditions of rural life permit a more democratic organization of the various societies than does urban life. The rural organization that makes its membership generally feel a sense of self-expression performs a very great service. One of the causes of discontent among rural people is the fact that so many find their life empty as far as adequate self-expression is concerned. What they crave is opportunity to do something worth while. At bottom they ask for privileges of self-assertion. The rural organization, as for example the Grange, comes into their life bringing them the opportunity 
for which they ask. At once they face the rural environment with a changed attitude of mind. In the labor world in the urban organization of industry it is becoming more and more difficult to give any adequate sense of self-assertion. Men are being forced to work for wages, and for nothing more. In spite of high wages they are naturally increasingly discontented. A great human craving is being crushed by the complexity of modern industry. This situation need not be duplicated in the country. Where the community is democratically organized and rightly led every individual may find some means by which to express himself so as to have a sense of personal importance. $\mathrm{He}$ is not merely a cog in a machine. $\mathrm{He}$ is a person, and what he does has some consequence. While he earns his living he also has opportunity to express desires that give him a consciousness of living a life worth while.

A great deal of the clash which is so frequent in modern social life is due to a desire of members of various groups for self-expression. They find it impossible to have any vivid sense of individual self-assertion, but they do feel the power of the group to which they belong. Of course their leaders are men and women particularly selfasserting. There have been and there still are many reasons why the farmer should develop class consciousness. To a certain degree this is 
inevitable under the present circumstances of economic organization. It is undesirable, however, for the farmer to allow self-seeking, self-assertive leaders to exploit this class feeling and develop it to a great degree. The wrong kind of leader often attempts to build his power upon the grievances of the farmer. What the farmer needs is not to feel his injustices more deeply, but rather to find a way out of his difficulties. His self-assertion as expressed in the economic world can get its fullest satisfaction by a constructive program that will bring to the rural worker a more reasonable share in the comforts and opportunities of modern life. In expressions of class hostility and discontent selfassertion melts away in mere feeling and leaves to the farmer no permanent or substantial result. Co-operation and constructive organization will carry him farther toward prosperity than will agitation and class consciousness.

Rural welfare requires that the farmer obtain all that really belongs to him. He must be organized; he must be industrially powerful; he must be self-assertive; he must have a program. It is for the good of the nation that he sense his needs and rights and that he back up his demands by a thoroughly organized self-assertion. In order, however, that his program may be sane, it is necessary that he have a correct understanding of all the conditions of modern life that concern him, and that he also 
have the most extensive contact possible with people outside his own environment. In other words, he can best win his social rights by a rational social program. In so far as he becomes the victim of scheming leadership, hungering only for a sense of power, he must fail to obtain the full measure of his present opportunity. Self-assertion may lead him astray if it is permitted to rob him of his good sense or bring him under the spell of the exploiting leadership which has become so great a menace in urban life.

\section{REFERENCES ON THE INSTINCT OF SELF-ASSERTION}

Adler, A., The Neurotic Constitution (B. Glueck, transl.). New York: Moffat, Yard \& Co., I917.

Bjerre, P., The History and Practice af Psychoanalysis (E. N. Barrow, transl.), chap. iv. Boston: Badger, I920. Blanchard, P., The Adolescent Girl, chap. iii. New York: Moffat, Yard \& Co., I920.

Edman, I., Human Traits and Their Social Significance, chap. viii. Boston: Houghton Mifflin Co., I920.

MacCurdy, J. T., "A Study of Human Motives," Proceedings of the International Conference of Women Physicians, Vol. IV. New York: The Woman's Press, I920. McDougall, W., An Introduction to Social Psychology, chap. vii. Boston: Luce \& Co., r9r8.

Tansley, A. G., The New Psychology and Its Relation to Life, chap. xviii. London: Allen \& Unwin, I920.

Tead, O., Instincts in Industry, chaps. vi, vii. Boston: Houghton Mifflin Co., 1918.

White, W. A., Mechanisms of Character Formation, chaps. viii, ix. New York: Macmillan, I9I6.

, The Mental Hygiene of Childhood, chaps. ii, iii. Boston: Little, Brown \& Co., I9I9. 


\section{VI}

\section{THE PARENTAL AND THE SEX INSTINCTS}

\section{PARENTAL INSTINCT}

One of the major instincts, by common consent the most important of all for social organization, is the parental instinct. In animal life, especially in its maternal form, it plays an increasing rôle with the ascending scale of nervous structure and complexity of conduct. Its biological and social significance was clearly established by Drummond in his Ascent of Man. The description of the parental or reproductive instinct and its allied emotion, tenderness, given by McDougall, has become a psychological classic. He writes:

From this stage onwards protection of offspring becomes increasingly psychical in character, involves more profound modification of the parent's behaviour and a more prolonged period of more effective guardianship. The highest stage is reached by those species in which each female produces at a birth but one or two young and protects them so efficiently that most of the young born reach maturity; the maintenance of the species thus becomes in the main the work of the parental instinct. In such species the protection and cherishing of the young is the constant and all-absorbing occupation of the mother, to which she devotes all her energies, and in the course of which 
she will at any time undergo privation, pain, and death. The instinct becomes more powerful than any other, and can override any other, even fear itself; for it works directly in the service of the species, while the other instincts work primarily in the service of the individual life, for which Nature cares little. All this has been well set out by Sutherland, with a wealth of illustrative detail, in his work on The Origin and Growth of the Moral Instinct.

When we follow up the evolution of this instinct to the highest animal level, we find among the apes the most remarkable examples of its operation. Thus in one species the mother is said to carry her young one clasped in one arm uninterruptedly for several months, never letting go of it in all her wanderings. This instinct is no less strong in many human mothers, in whom, of course, it becomes more or less intellectualized and organized as the most essential constituent of the sentiment of parental love. Like other species, the human species is dependent upon this instinct for its continued existence and welfare. It is true that reason, working in the service of the egoistic impulses and sentiments, often circumvents the ends of this instinct and sets up habits which are incompatible with it. When that occurs on a large scale in any society, that society is doomed to rapid decay. But the instinct itself can never die out, save with the disappearance of the human species itself; it is kept strong and effective just because those families and races and nations in which it weakens become rapidly supplanted by those in which it is strong. ${ }^{\mathrm{x}}$

The parental instinct has always a large importance in the rural environment. From many viewpoints the country seems particularly favor-

' McDougall, An Introduction to Social Psychology, pp. 69-7I. 
able to the best social expression of this important instinct. At any rate the rural family does not suffer some of the handicaps necessarily placed upon the family of the city. On the whole, therefore, the parental instinct is especially significant as it operates in the social life of country people. Parents are likely to be with their children more in the country than is possible in any other environment. This is notably true during the children's long summer vacation. The working conditions of farm life tend to bring into association the several members of a family; for, indeed, much of farming in America still remains in some degree a family industry. The son works with his father in the fields; the daughter helps the mother with the housework. Even the recreation of the children is apt to be more often under the eye of the parents than is ever possible in the urban environment.

It follows that the rural family performs a larger function along educational lines than would be feasible under different industrial and social conditions. The companionship between parents and children makes it easy for the parents to impress their standards of life strongly upon their children. Their influence meets less competition than does that of city parents. Although this greater effectiveness of parental relationship works both ways, according to the character of the home, so that some children are hampered in their life-preparation 
by family influences, while others are benefited, nevertheless in either case the power of the parental instinct shows itself.

As the importance of family atmosphere in its operations upon the life of the growing child becomes more commonly recognized there will surely follow greater and greater effort to conserve for social welfare the tremendous opportunities provided by the home. Country conditions, however, will always present the most favorable environment for the utilization of parental opportunity. From the country has been coming the influence of the most stable home; in the future we have reason to expect from the country the most effective educational contribution that family life can make.

There is nothing more characteristic of the average parent than a desire to secure for his children better conditions than he himself enjoyed. This desire is especially the modern expression of the parental instinct. Even animals care for their young. Modern man is not satisfied with mere protection; he desires to provide new and more favorable circumstances of life. In other words, he reacts against his own mistakes and limitations by eagerly striving for easier conditions for his children. Tead tells us ${ }^{x}$ that one of the causes of industrial unrest is the desire of parents to improve

x Tead, Instincts in Industry, p. I4. 
their lot so as to insure a more wholesome life for their children. While country people express it differently from factory operatives, for example, yet this is one of the ever present and profound motives in family ambition.

The way the parents' desires for their children's advancement show themselves depends on the general attitude of the parents toward country life, and the community conditions that the family experiences. Where farm life seems hard and barren, the income inadequate, and the toil excessive, parents may be pardoned for wanting their children to take up some other occupation than farming. That this is the wish of many parents no one can doubt who has ever investigated the reasons young people have for leaving the country. In such cases the mother appears more aggressive in impelling the children toward the town or city. This may be in part because of a more intense parental instinct in the mother and at times because she feels more deeply than does the father the unsatisfactory conditions on the farm. On the other hand, when the parents are happily situated and thoroughly in sympathy with country life they naturally encourage their children to remain in the country unless they clearly see that because of special endowment or peculiar taste a child cannot wisely keep to the rural environment. 
This normal wish on the part of country parents to advance their children lays an excellent foundation for community progress. The parent-teacher association is well adapted to utilize parental ambition in ways that further social welfare. It is to be regretted that there are not more such organizations in rural districts. By bringing together teachers and parents and children, family ambition is naturally carried over into social betterment. Anyone who knows at first hand the work of a good parent-teacher association in the country appreciates the value of one of the happiest and most useful of gatherings for rural people. Where the organization has been started and died out, the trouble seldom is any lack of parental interest, but rather a failure to bring this interest to wholesome expression. The lack of success is most often due to ineffective leadership.

At one point it would seem as if the parental instinct were ineffective. Country people often seem niggardly with reference to school expenditures. They obstruct educational progress and work against improvement of teaching force, equipment, recreational facilities. They argue that what was good enough for them is good enough for their children. But all the facts with reference to the countryman's attitude toward taxation do not stand forth upon the surface. In the country, taxation is largely direct and con- 
scious; moreover, the family income is not uncommonly such as to make economy necessary, and it is not strange that the farmer starts retrenchment in community expenditure. There is also honest doubt frequently about the so-called improvements. This feeling of suspicion may be rooted in previous experiences, for everyone who attempts reforms in the country must remember that others have preceded him, and that country folk have suffered considerably from unwise experiments and irresponsible propaganda. When parents are sure that their increased tax actually does mean appreciable advantage to their own children, they do not normally refuse to accept their share of the burden. They are naturally careful in regard to public expenditure, as city people would be if they were more conscious of their own contribution to the public tax.

Rural life largely centers about family interest. A great deal of the community life rests upon a family structure rather than the association of individuals as such. Much of the influence of country life conserves and strengthens family affection. The members of the family are more closely united, since they escape the scattering tendency necessarily present in a highly gregarious society. The close association and the common motives of the normal rural home deepen love much as struggle with poverty does for many of the 
poorer families of the cities. It is this drawing together under the impulse of common interest which explains the possibility of several families living under one roof, as occasionally happens in the country. Sons and daughters marry and the new family is incorporated in the parental home. The sense of common personal interests is strong enough to overcome the risk of close association between mother-in-law and daughter-in-law and the other relationships made by marriage.

This basic sense of common interest could not be maintained so easily were it not that farming is still an industry that to a large degree has a family foundation. If the working members of the family all scattered after breakfast to different parts of the locality to do different tasks with no common understanding of the various forms of occupation represented, as do urban workers, it would be impossible for so many composite families as are found at present in the country to exist in a reasonable degree of content and happiness.

It is, of course, impossible to have so thoroughly organized a rural family without suffering from social evils. One of the outstanding misfortunes in the community life of the country is excessive family competition. The ambition of parents, reinforced by the self-assertive and pugnacious instincts, leads to intense rivalries and jealousies between families. This unfortunate relation exists 
between relatives and neighbors and especially among families that compete for leadership in the community enterprises.

Family competition in the country sometimes passes over into family feuds, and in the older rural sections these divisions pass on from father to son in a most surprising manner. Occasionally a community is hopelessly separated by the implacable rivalry existing between families that once were friendly, but that for many years have bitterly fought one another. The quarrel is liable to be carried into the church or the school or some other community undertaking, and much of the energy of the people is wasted in foolish antagonism. These feuds are sometimes fundamentally pathological. They originate in the abnormality of some member of a family, who has become so sensitive or so jealous or so quarrelsome as to demonstrate his departure from the normal. The real situation, however, is seldom understood by the community, and the pathological individual, who may indeed be mildly insane, nevertheless rallies his friends and relatives to a warfare which continues even after his death.

$\mathrm{McD}$ ougall assigns the emotion of tenderness to the reproductive instinct. In large measure pity is a derivative of the parental instinct. On the whole, pity is strongly expressed in country life, as one would expect from the strength of the 
instinct that feeds it. Country conditions provide many opportunities for the development of pity, particularly in early life, at the time when the expression of this emotion is most infrequent. In addition to the care of the child the adult has numerous chances to show tenderness toward animal life, and in rare cases the feeling is carried over in relation to plants and trees. The attitude of the mother animal and the weakness of her offspring impress the average countryman more often than he is likely to admit. There is a stoical philosophy among the rural people of America, particularly in the older parts, that leads the men to cover up their inherent tenderness lest they be accused of sentimentalism. The close observer, however, discovers easily that there is in the country a sympathetic attitude toward the young and helpless which is directly related to the strong parental instinct. Of course it is with reference to children that this is most clearly seen. Where life is not economically too hard nor toil so excessive as to destroy the people's vitality, parents usually make much of their children and obtain deep satisfaction from their affectionate relationships. There are influences in the country, especially those that come from the slaughtering of domestic animals, that tend to harden and give an indifferent attitude toward life; but as a rule, in contact with children, the average father and 
mother express to the full the highest development of the human parental affection.

In the rural environment pity is by no means confined to one's own children or even to one's own household or relatives. Neighborhood spirit has never been carried to a finer expression along lines of human sympathy than in the American rural community. This is most clearly demonstrated with reference to tragic events. The coming of death or accident or illness into the home brings forth sympathy and practical assistance. A fire, for example, shows the spontaneous expression of community sympathy. It is more than curiosity and craving for excitement that brings together from all directions men and women in the endeavor to put out the fire. If they fail, and the fire completes its destruction, there follows frequently very tangible evidence of genuine sympathy. The entire community, as it were, makes contributions, that the home may be rehabilitated. Some give their labor, some give material, some give money, and few indeed there are that give nothing. Although sympathy is perhaps more composite than tenderness, without question they both draw nutriment from the reproductive instinct. Sympathy and tenderness have been freely expressed in the country in cases of illness. This is not so true at present as it has been. Some keen observers of country life con- 
ditions regret exceedingly the passing of neighborhood nursing. In so far as the change has come about, it is due to several influences. In the first place, even in the country the service of the professional nurse is increasing. In the second place, there can be no doubt that the fear of contagion has greatly decreased neighborhood nursing; and - since there has been an inadequate knowledge of bacteria, there have grown up ill-founded and superstitious ideas regarding contact with the sick. In part, also, urban influences have been at work, and it must be admitted that to some extent the change represents a melting away of neighborhood spirit. There still remains, however, a much greater neighborhood concern for those sick or bereaved than usually occurs in the city, even in the same apartment house, or in the suburban community, even on the same street.

\section{SEX INSTINCT}

Although the sex instinct is fundamentally related to the parental instinct, it of course must be distinguished and given its separate analysis. It is without question one of the most powerful and most necessary of all human urges. As it functions in human life it is exceedingly complex, and in its psychic expressions not always easily recognized. In other words, in a normal human being, sex is something! more than physical. The 
Freudian psychology attempts to deal with the psychic by-products as they are expressed in modern social life. There is no reason to suppose that the sex instinct is weaker or stronger in the rural environment than in any other, nor is it more simple or more complex. It is unreasonable to suppose that the rural environment fundamentally influences the sex instinct to increase it or to decrease it, or to give it any rigid environmental expression; but without doubt the effect of the environment can be seen in social conditions that are largely originated by sex interests.

The sex instinct in the country tends to express itself in its inherent simplicity. It may be conscious or unconscious in the life of the individual, but in either case it is more largely unadulterated sex than can be true in the gregarious environment of the city. The mutual attractiveness of the adolescent boy and girl in the country, for example, is undisguised and is accepted by everyone as according to the natural order. The emotion of love, largely derived from this powerful instinct, is frankly taken for granted and not covered up by the subterfuges which are maintained to some extent in urban society.

It is hardly possible for rural young people to escape the knowledge of sex. It stands out prominently in the environment, especially with reference to the domestic animals. The boy par- 
ticularly becomes acquainted with sex in one form or another very early, and the country girl has greater knowledge of it as a factor of life, class for class, than does her city sister. Unfortunately a considerable amount of rural conversation centers about sex in the average community. This by no means indicates that rural people are more sexual or more interested in sex than are people in the town or city, but rather that they handle the matter more directly and more frankly.

The freedom in the country and the need of the greatest possible use of opportunities for association have led to a precocious courtship, which on the whole seems detrimental to the best interests of the growing boy and girl. It would be better if the association of the sexes in the adolescent years could be more a comradeship and less a premature development of mature attractiveness. It stands as the opposite extreme from the unwholesome separation along lines of normal association, which often takes place between the boy and girl in the suburban and city society.

It is surprising to see how greatly rural communities differ with reference to unwholesome expressions of sex interests. Apparently two communities near together, or even two neighborhoods of the same farming section, may be radically different. One will be altogether wholesome and free from any immorality; the other will main- 
tain low standards and in proportion to the population will have a large degree of vice. It must be realized that the freedom and isolation of the country make vice possible where the traditions and standards of the community are such as to encourage it. When one considers the freedom that the average American country community permits the young man and woman, the almost entire absence of chaperonage, the "two is company, three's a crowd" code, buggy and automobile two-by-two driving parties, it speaks well for the general wholesomeness of country life that we so infrequently have sex tragedies. Investigations such as have been made do not demonstrate any exceptional amount of illegitimacy; and yet there is little artificial barrier to sex interest. The general tone of the community is the real protective influence which forbids any considerable sex problem. Curtis, in his Play and Recreation for the Open Country, gives a just description of the average country morality in the following words:

There seems to be a general feeling that moral conditions are bad in the city and good in the country, but I question if this is so. The city has its great criminals and philanthropists; it furnishes the rich soil in which all things grow rank. The country does not produce the great saints or the great sinners. It has no prostitution, but there are probably quite as many loose young people in the country as in the city. The hired man who goes to town to "have a good time" is apt to get drunk and visit the worst type of houses. Immoral tales and obscene language are a large 
part of the conversation of hired men and country boys. The sex instinct is very insistent in the teens, and there is gathered about it the romance of love. Country youth are not usually chaperoned, and there are abundant opportunities for seclusion. Add to this the fact that there often is little else to think of, and you have a condition out of which immorality will always grow. There is scarcely a social occasion which is not beset with temptations, the dances are generally held in the woods or at hotels, and walks and drives are solitary. The country must give a proper organization to its social life if it is only for the sake of the boys and girls. ${ }^{\mathrm{I}}$

The feeble-minded girl stands out as an exception. Her inherent weakness of control makes it easy for the more selfish men to exploit her. She becomes the mother of illegitimate children, and constitutes in the country, as she does in the city, a special sex problem which at present cannot be solved unless she is carefully protected from those who would prey upon her mental deficiency. Individual feeble-minded girls in the country have been known to give birth to as many as seven or eight illegitimate children, each having a different father. A few such girls necessarily lift the record of illegitimacy out of all proportion, and give the community as a whole a reputation it does not at all deserve.

In unprogressive communities of low standard there are certain influences that come forth from the rural environment to affect unfortunately sex

${ }^{x}$ Curtis, p. 245. 
relations. One of these influences is the atmosphere of repression. Where the church preaches asceticism and frowns upon wholesome pleasures and recreations, giving Christianity a morbid interpretation which must alienate wholesome young men and women, the association of the youth of the community loses much of its elevating character. There is frequently a driving down of youthful idealism to lower levels created by the meaner types. The entire community life seems thrown out of gear, and, since nothing functions properly, it is not at all strange that the sex instinct bursts forth to the permanent injury of the less disciplined individuals. Social repression leads directly to sex self-consciousness and vicious associations. The remedy is as clear as the cause.

Monotony also has an unwholesome influence upon the sex instinct. Where little happens and young life finds no appealing recreations, it is natural that there should be emphasis upon sex. Among the young, the instinct of sex always has momentum enough to fill any social void, and where the life sickens of dreary monotony it must not be thought strange that relief is often discovered in sex interests that invariably express themselves in vice. Here again the remedy stands forth on the surface. It is by filling up the life of the young with wholesome opportunities and influences that theysex instinct is forced to take 
its proper place and show itself in the sublimated mutual respect of wholesome affection between men and women.

There is one peculiarity that occasionally is to be found in rural communities. Although the general standard of morality is high, at one point there is a strange exception. This consists of a number of homes in which the man and woman live together unmarried. It is difficult to understand why year after year two individuals should live together, to all outward appearances husband and wife, and yet remain unmarried. A recent study of such homes in a small rural community revealed a most unreasonable proportion of men living with their housekeepers for many years, the two regarded, so far as community opinion was concerned, as husband and wife. The situation is accepted by the community as a matter of course, and attracts little attention. It is only the outsider who comes into the place who marvels at the inconsistency of a code of morals particularly strict with reference to most sex matters and extremely lenient to one type of variation. Religious revivals in the country have been known to bring about the wholesale marrying of couples who for years have seemed to live together the most intimate home life.

The rural community has not yet reached its greatest efficiency in the social utilization of the 
normal attraction of the sexes. It is impossible to control the sex instinct satisfactorily by direct effort. This particular instinct serves society best when it is sublimated in young life, and its energy drawn forth into various channels that lead toward community wholesomeness. An active, progressive, and sympathetic church can do much in the country to give young people wholesome contacts and satisfying recreation, thus keeping sex as a physical element in the background. The efficient modern school with a reasonable equipment and well-trained, socially minded teachers, who are mature and experienced and yet not hostile to youth, can do a great deal to give young people proper attitudes toward life, and the chivalry and intellectual interests which naturally provide social discipline and self-control. The community itself, in the last analysis, is the determining factor in evolving the behavior of its young people. If decency and high standards are generally maintained, the sex problem is reduced to a minimum.

All things considered, rural morality maintains itself at high levels. As Warren Wilson points out in a very fair estimate of present conditions, there has been decided improvement in rural ethics so far as they have to do with matters of sex. It is not commonly known how great in some localities this improvement has been. The statement of Dr. Wilson is as follows: 
The investigations of the Country Life Commission brought general testimony to the high standards of personal life which prevail in the country. In such a representative state as Pennsylvania the standard of conduct between the sexes was found to be good. The testimony of physicians, among the best of rural observers, was nearly unanimous, in Pennsylvania, to the good moral conditions prevailing in the intercourse of men and women in the country. This indicates that the farmer economy had superseded the economy of the pioneer.

The moral problem of the pioneer period consisted of a struggle for honesty in business contracts, and purity in the relation of men and women. The story of every church in New England and Pennsylvania, until about 1835 at which Professor Ross dates the beginning of the farmer period, shows the bitter struggle between the standard accepted by the church and that of the individuals who failed to conform. The standard was inherited from the older communities of Europe. The conduct of individuals grew out of the pioneer economy in which they were living. Church records in New England and New York state are red with the story of broken contracts, debt and adultery. The writer has carefully studied the records of Oblong Meeting of the Society of Friends in Dutchess County, New York, and from a close knowledge of the community through almost twenty years of residence in it, it is his belief that there were more cases of adultery considered by Oblong Meeting in every average year of the eighteenth century than were known to the whole community in any ten years at the close of the nineteenth century. The farmer economy in which the group life of the household prevailed over the individual life had by the nineteenth century superseded the pioneer period, in which individual action and independent personal initiative were the prevailing mode. ${ }^{x}$

'Wilson, Evolution of the Country Communily, pp. I7I, I72. 


\section{REFERENCES ON THE PARENTAL AND THE SEX INSTINCTS}

Blanchard, P., The Adolescent Girl, chap. ii. New York:

Moffat, Yard \& Co., I920.

Breckinridge, S. P., and Abbott, E., The Delinquent Child

and the Home, chaps. vi, vii. New York: Charities

Publication Co., I9I2.

Brown, H. W., "The Deforming Influences of the Home,"

Journal of Abnormal Psychology, April, rgr 7.

Ellis, H., "Sex in Relation to Society," Studies in the Psychology of Sex, Vol. VI. Philadelphia: F. A. Davis, I9ro.

Freud, S., A General Introduction to Psychoanalysis (G. S. Hall, transl.). New York: Boni \& Liveright, 1920.

— Three Contributions to the Sexual Theory (A. A. Brill, transl.). New York: The Journal of Nervous and

Mental Disease Publishing Co., rgro.

Groves, E. R., Moral Sanitation, chap. vi. New York: Association Press, I9r6.

$\longrightarrow$, Rural Problems of Today, chaps. i, ii. New York: Association Press, 1918.

Hall, G. S., "Sex Vicariates and Sublimations," Proceedings of the International Conference of Women Physicians,

Vol. V. New York: The Woman's Press, I920.

Hollingworth, H. L., and Pfoffenberger, A. T., Applied Psychology, chap. v. New York: Appleton, I9r 7.

Israel, H. (ed.), The Home of the Countryside. New York: Association Press, r9r7.

Jung, C. G., Analytical Psychology (C. E. Long, transl.). pp. 132-55. New York: Moffat, Yard \& Co., I9ı6.

Knight, M. M., Peters, I. L., and Blanchard, P. Taboo and Genetics, pp. 247-6o. New York: Moffat, Yard \& Co., I920.

Lay, W., The Child's Unconscious Mind, chap. vi. New York: Dodd, Mead \& Co., I9r9. 
McDougall, W., An Introduction to Social Psychology, chap. x. Boston: Luce \& Co., 1918.

Moll, A., The Sexual Life of the Child (E. Paul, transl.). New York: Macmillan, IgI 2.

Tansley, A. G., The New Psychology and Its Relation to Life, chaps. xxi, xxii. London: Allen \& Unwin, 1920. Tead, O., Instincts in Industry, chaps. ii, iii. Boston: Houghton Mifflin Co., rgr8.

Vogt, P. L., An Introduction to Rural Sociology, chap. xi. New York: Appleton, 1917.

White, W. A., "Extending the Field of Conscious Control." Proceedings of the International Congress of Women Physicians, Vol. V. New York: The Woman's Press, I920.

- Mechanisms of Character Formation, chap. vii. New York: Macmillan, ı9ı6.

- The Mental Hygiene of Childhood, chap. viii. Boston: Little, Brown \& Co., I9rg. 


\section{VII}

\section{FEAR}

Modern psychology makes much of fear. By some writers it is classed among the instincts, by others among the emotions. Watson defines it as one of the three emotional reactions belonging to the original and fundamental nature of man, the other two being rage and love. ${ }^{\text {I Th }}$ Tefinition does justice to both the spontaneous origin of fear and its emotional quality. It has long been recognized that the emotion of fear is one of the most powerful impulses that influence conduct. James, many years ago, pointed out that fear exercises an unwholesome sway over human behavior:

In fact, the teleology of fear, beyond a certain point, is more than dubious. A certain amount of timidity obviously adapts us to the world we live in, but the fearparoxysm is surely altogether harmful to him who is its prey. ${ }^{2}$

\section{Again he writes:}

Fear has bodily expressions of an extremely energetic kind, and stands, beside lust and anger, as one of the three most exciting emotions of which our nature is susceptible. The progress from brute to man is characterized by nothing p. 199.

${ }^{s}$ Watson, Psychology from the Standpoint of a Behaviorist,

${ }^{2}$ W. James, Psychology, Brief Course, p. $4 \mathrm{II}$. 
so much as by the decrease in frequency of proper occasions for fear. In civilized life, in particular, it has at last become possible for large numbers of people to pass from the cradle to the grave without ever having had a pang of genuine fear. Many of us need an attack of mental disease to teach us the meaning of the word. ${ }^{\mathrm{r}}$

It is only of late, however, that the full significance of this emotion as it operates in man's social life has been disclosed by science. This is because the psychic manifestations of the emotion were not clearly understood. The emotion shows itself in such a variety of ways that it frequently escapes responsibility for its influence upon conduct. Even in the animals fear has many characteristic expressions. In man's life it is immensely more complicated.

The influence of fear in the primitive life of man has long been realized. It has had a great deal to do with the development of human society. How large a part of savage life is influenced by fear is shown by the ethnological studies of investigators, who, by study and association with the natives, have become familiar with the social life of a particular tribe or people. In early society fear had a constructive value, for it was necessary as a method of social control. It made for peace and order and stability of organization. The will of the tribe or village was adopted by the indi-

Ibid., p. 408. 
vidual in part because of the enormous risk he feared if he ran contrary to the desires of his associates. The following description of the social control of the American Indian is a vivid illustration of the significance of the fear element:

Certain qualifications will be made presently; but in general the absence of central authority is one of the most impressive features of North American society. It might be imagined that a chaotic condition was inevitable under these circumstances. But that would be leaving out of account the tremendous, not to say terrific, force of established custom and public opinion. To meet with universal reprobation on the part of one's neighbors; to have derisive songs sung in mockery of one's transgressions; to be publicly twitted with disgraceful conduct by jokingrelatives-these were eventualities to which no Indian lightly exposed himself. They made it possible to dispense largely with a powerful executive and with penal institutions; while the customary law sufficed, rendering new legislation unnecessary. ${ }^{\mathrm{x}}$

In animal life everybody recognizes the large place fear occupies. Of late science has been making clear the fact that modern man is more susceptible to fear than has been suspected. Fears excessive in view of the actual circumstances as judged by the unprejudiced observer are classed as morbid. The amount of such morbidity in modern life is surprising to those unfamiliar with the field of abnormal psychology. In addition to such obses-

${ }^{2}$ R. H. Lowie, Primitive Society, p. 385. 
sions, fear operates much more commonly in psychic by-products, such as worry or persistent anxiety. In childhood we find ideas of physical danger predominating, and few children escape intense suffering from one kind of fear or another. Although under the necessary stimulation physical fear expresses itself in every normal adult, it is primarily in the psychic realm that fear in modern life operates after maturity. The emotion shows itself, of course, in every environment. Its influence upon rural life, however, is considerable, and any attempt to trace its effect throws light upon the social mind of the country.

Recent psychology has placed great stress upon the importance of protecting the child from experiences of fear. A large number of the nervous difficulties of adult life are found to be connected with early childhood fear experiences. There are innumerable opportunities for such childhood injuries in the rural environment. The contact with animal life makes possible one of the most natural forms of fear reaction. Primitive man was protected largely from dangerous wild animals by his quick instinctive fear attitudes, and the little child easily becomes a victim to the fright that reacts as if it were concerned with the same sort of experience. The nature of the rural environment provides opportunity for the child in his first association with domestic animals to feel fright. 
In every community there are adults, who, not understanding the serious injury that a child may obtain from being frightened, enjoy seeing the child made afraid. Anyone who has lived his early life in a country place has come in contact with persons who use every opportunity to instil fear in children. For example, the farmer has to accept often such farm help as he can get, and as a consequence many of the farm laborers are unwholesome in their relations with children. The effect of such persons in instructing youth in vice is rather generally recognized; their influence in the instilling of fear is equally injurious.

Another source of fear injuries in the young child is the stories and superstitions that often impress him. Much of the conversation in isolated communities, especially when recreation occupies a very small place, is with reference to experiences that build up in the child ideas that stimulate fear. Even the most thoughtful parent, who is consciously trying to protect his child, is unable to direct the conversation of guests, who in the presence of children repeatedly turn with morbid pleasure to the recital of events that excite fear. The country child has a greater degree of solitude than the suburban or town child. Often he is expected to go into dark buildings at night or travel the road for long stretches where there are no inhabitants. If, by any process, fear has been 
suggested, it becomes easy for the child through his imagination to suffer keenly and to picture episodes and dangers that augment earlier fear experiences. If country parents clearly saw the difficulties of the child, many of these early frights could be prevented. The rural child is also liable to have early knowledge of death under such circumstances as to add a morbid character to the funeral or the death. Such happenings stand out in the life of the country child with more distinctness and therefore have greater consequence than would be true if the environment were more filled with occurrences. In some communities a great deal of fear suggestion originates in the school or church. Boris Sidis tells us that the wrong sort of Sunday-school teaching is a serious source of later morbid obsessions and nervous difficulties. The atmosphere of some country churches provides a sympathetic background for suggestions of fear in the Sunday-school instruction. The rural cemetery sometimes becomes a cause of unfortunate early suggestions. Many of these childhood impressions remain in the life and do harm.

The child's risk of injury through the emotion of fear is not, however, confined merely to the realm of physical danger. The child, like the adult, can suffer from the psychic by-products of fear. In the school, especially, teachers who do not 
understand the working of the minds of children, or who are indifferent to the welfare of children, may by their punishments, their criticisms, their discipline, and their use of ridicule lessen the child's self-confidence and magnify the timidity of some children so that the inherent weakness of the personality is greatly increased. We cannot appreciate the full significance of these experiences for the rural child unless we put ourselves in his place and realize that he supposes, in many cases, that his punishment or criticism becomes generally known in the community. It is this interest of the country community in school punishments and failures that makes them so prolific in permanent injuries to the child. There is risk also that the comparative solitude of the child, his very limited opportunity to meet strangers, construct in his life a permanent self-consciousness which later makes association difficult. This timidity is a mild form of fear, and the self-consciousness of later life is an offshoot of the emotion of fear.

There is one reaction of this emotion in country life which fortunately is not common. There are brutal parents and drunken parents and nervously irresponsible parents in the rural environment as elsewhere. In such homes unspeakable exhibitions of anger or cruelty play havoc with the child. Probably imagination cannot picture the suffering of children who in isolated country homes endure 
fearful punishment or fear terrible things that they suppose liable to come upon them. The close contact of family with family in the city largely protects the child from such experiences. In addition the protective societies are always ready in the urban environment to enter such homes for the protection of the child when once the character of the home becomes known. The average rural community will endure a great deal before it will complain against a home or make any practical effort to rescue the child from cruel or irresponsible parents. Social workers in the country know from personal experience case after case that illustrates the unwillingness of the usual community to handle with dispatch and justice cases of family cruelty. The injury that a young child may receive from such usage is tremendous. When it becomes more generally known in the rural community what a fearful thing it is to charge young life with fear, public opinion will deal more heroically and more quickly with such homes.

The meager and routine life of many children in the country decreases their native sense of confidence and builds up a hesitancy in facing new environment and new conditions of life. A good deal of the conservatism of rural people is built upon a sense of fear in facing new things . Many country children endowed with considerable talent are unable to express their powers 
because of lack of courage. Their early experiences have weakened their willingness to venture, or their feelings of self-sufficiency. As a result they react to new opportunity with fear. In this way much of the promise of country life is permanently lost. Potential leaders never exercise their natural gift. It must be even more true of potential artists, inventors, and speakers. Such organizations as the Boy Scouts, the Campfire Girls, and the Young Men's Christian Association do a very great service to the country child in providing opportunity in the group for adventure experiences, rivalry, and contact. They rescue the child from the pressure of routine and uniformity and give confidence to the native ambitions. At the present time one of the pathetic losses of country life is the check that self-consciousness has upon a multitude of persons in forbidding them free expression in their community associations. Each in turn is hampered by regard for the others. This explains the awkwardness, the hesitations, and the barrenness of a great deal of the social life of the country. Fortunately organized play and co-operative effort are in recent years melting away this hampering self-consciousness in the gatherings of country people. The greater the isolation, the greater we find the lack of freedom on the part of country people at their gatherings. Such self-consciousness is a derivative of the 
emotion of fear and gets its original impetus from childhood experiences.

In estimating the value of any rural organization, it is necessary always to take into account the good it accomplishes merely by providing a meeting-ground for the people of the neighborhood or community. Sometimes when the organization carries out its formulated purpose most imperfectly, it nevertheless adds much to the life of the people because it draws them into association and permits them to have the experiences that do so much to remove shyness and selfconsciousness. The urban observer of country organizations often judges them most erroneously because he assumes that the business at hand should be disposed of expeditiously. Just as he often misjudges the farmer's industrial habits because the farmer is so willing to drop work temporarily for a conversation with the casual visitor, so he forgets that one of the purposes of the meeting together of country people is the opportunity they have for free conversation. Were the rural people to come together and do their business with dispatch, and then return to their homes, a large measure of the worth of their association would be lost. It is distinctly unfair to make any comparison at this . point with the apparently more business-like methods of urban organizations. In the one case 
the members of the group are satisfied with group contact and wish only to get through their business as quickly as possible; in the other case there is a deep human craving for the advantages of association, and therefore the meeting lengthens out or is preceded by a delay in starting work, which gives the people one of the satisfactions, the desire for which led them to come together.

It is generally realized that one of the great burdens of rural life is its comparative isolation. This condition provides opportunity for the emotion of fear in one way or another to express itself. Many of the women in the country suffer keenly when they are left alone or when for any reason the sense of isolation is aroused. Occasionally in order to be free from this hardship the family moves to town. In some rural sections of the South, because of race friction, both husband and wife feel in the isolated homestead a degree of fear which even mounts at times to terror. No one can understand the occasional uprising against negroes accused of crime, in the isolated rural sections of the South, unless he sees the emotion of fear working constantly in the everyday life of the people. The possibility of arousing the feeling of fear in the lonely house hampers the freedom of the farmers to a considerable degree. The father and mother often find it impossible to go out at night together because of the unwilling- 
ness of the children to be left alone. Sometimes it is necessary that the parents should leave the house in charge of the older children, and as a result the children experience long hours full of fearful imaginings, which may build up a prejudice in their minds against the rural environment. Country people have the habit of attending evening meetings and parties as family groups, in a way that is never duplicated in the urban environment. The reason for this is the fact that it does not seem safe to leave the younger members of the family at home. To some extent this is a deterrent against association, for it is sometimes difficult to get all the members of the family ready for a social event. The tired mother, rather than prepare her five or six children for a decent appearance at the church social or neighborhood party, gives up the idea of going.

Modern communication, particularly the telephone, has been of immense service in lessening to a considerable degree the sense of fear in rural isolation. Much, however, depends upon the temperament of the persons concerned. Everyone familiar with country life knows numerous cases where mothers or children become captive to the emotion of fear and suffer terribly as a result of their own morbid imagination. Unexpected or strange noises from the barn drag many a conscientious woman, left alone at home 
on a winter's night, from the house; and, lantern in hand, she investigates all the recesses of the barn and sheds, often trembling with fear as she performs the task she dare not leave undone, and by her own fear suggesting terror to the child.

In his fascinating picture of English rural life nearly a century ago, William Howitt gives us this vivid description of the discomforts of rural isolation:

The citizen who lives in a compact house in the center of a great city, whose doors and windows are secured at night by bars, bolts, shutters, locks, and hinges of the most approved and patented construction; who, if he look out of doors, looks upon splendid rows of lamps; upon human habitations all about him; whose house can only be assailed behind by climbing over the tops of other houses; or before, by eluding troops of passengers and watchmen, whom the smallest alarm would hurry to the spot; I say, if such a man could be suddenly set down in one of our many thousand country houses, what a feeling of unprotected solitude would fall upon him. To sit by the fire of many a farm-house, or cottage, and hear the unopposed wind come sighing and howling about it; to hear the trees swaying and rustling in the gale, infusing a most forlorn sense of the absence of all neighbouring abodes; to look on the simple casements and the old-fashioned locks and bolts, and to think what would their resistance be to the determined attack of bold thieves; - I imagine it would give many such worthy citizens a new and not very enviable feeling. But if he were to step out before the door of such a house at nine or ten o'clock of a winter or autumnal night, what a state of naked jeopardy it would seem to stand in. Perhaps 
all solitary darkness;-nothing to be heard but the sound of the neighbouring woods; or the roar of distant waters; or the baying of the ban-dogs at the scattered and far-off farm-houses; the wind puffing on him with a wild freshness, as from the face of vast and solitary moors; or perhaps some gleam of moonlight, or the wild, lurid light which hovers in the horizon of a winter-night sky, revealing to him desolate wastes, or gloomy surrounding woods. In truth, there is many a sweet spot that, in summer weather, and by fair daylight, do seem very paradises; of which we exclaim, in passing, "Ah, there could I live and die, and never desire to leave it." There are thousands of such sweet places, which, when night drops down, assume strange horrors, and make us wish for towers and towns, watchmen, walkers of streets, and gaslight. ....

This may seem rather exaggerated, read by good daylight, or by the fire of a city hearth; but this is the natural spirit of the solitary house. It is that which many a one has felt. It has cured many a one of a longing to live in a "sweet sequestered cot"; nay, it is the spirit felt by the naturalized inhabitants of such solitary places. I look upon such places to generate fears and superstitions too, in no ordinary degree. The inhabitants of solitary houses are often most arrant cowards; and for this there are many causes. A sense of exposure to danger, if it be not lost by time, is more likely to generate timidity of disposition than courage. Then, the sounds of woods and waters; the mysterious sighings and moanings, and lumberings, that winds and other causes occasion amongst the old walls and decayed roofs, and ill-fastened doors and casements of large old country houses, have a wonderful influence on the minds of the ignorant and simple, who pass their lives in the solitude of fields; and go to and fro between their homes and the scene of their duties, often through deep and 
lonesome dells, through deep, o'ershadowed lanes by night; by the cross-road, and over the dreary moor; all places of no good character. Superstitious legends hang all about such neighbourhoods; and traditions enough to freeze the blood of the ignorant, taint a dozen spots round every such place. ${ }^{\mathrm{x}}$

Such fears are greatly stimulated as the result of any tragic event. Nothing travels so rapidly amongst country people as reports of accidents and calamities. Occasionally a whole community is terrorized, especially when in their midst some undiscovered person is afflicted with criminal impulse. In one remote Maine community, one summer, building after building was burned. The entire village was demoralized with fear and suspicion. It finally became so permeated with feelings of insecurity that everyone suspected his fellows. It was a veritable reign of terror until eventually the mentally deficient person was located.

It must not be forgotten how the emotion of fear, particularly as it expresses itself in anxiety, can be heightened by a personal tragedy. At this point we touch one of the profound hardships of some country people. When the getting or not getting of the doctor makes the difference between life and death, the matter of distance from the village where the doctor is to the remote farm where the child or wife lies ill is of paramount importance. The inevitable delay in obtaining

I William Howitt, The Rural Life of England, pp. 134-37. 
medical assistance in such cases is never forgotten by one who has had the experience. If he continues life in the country his sense of isolation may be enormously increased by the memories of what happened or was narrowly averted. There are times also when the coming of the doctor does not eliminate this sense of rural handicap in the presence of accident or disease. The home into which affliction has entered realizes that the situation is beyond the skill of the general practitioner, and that there is no time to call from the distant city the qualified expert. Under such circumstances many a mother or father vows never again to be caught away from efficient medical skill. However versatile the country doctor may be, he is forced at times to face responsibilities for which he is not adequately fitted. If he frankly acknowledges this, the anxiety of the home is still more increased. These happenings are among the most painful experiences of country people, and at such times the inhabitants of rural districts suffer a keen sense of environmental limitation from which the poorest city family is protected.

An element of fear appears in the growing group consciousness of farmers. Any form of class contest is in part built upon an emotional attitude based upon the fact that the rivaling group is supposed to be an opposing menace. At the present time this is seen particularly in the industrial 
field. Capital frequently acts in labor troubles from a fear-complex basis. The employer's attitude is not so much conditioned by the issue at stake as by the fear that an imaginary program of labor will be brought forth later, and the immediate contest is a preliminary test of strength. The corporation is unwilling to give way to pressure for fear that additional and increasing demands will be made by the employees. The same attitude is maintained by the labor forces. They desire to win the strike, for example, not merely that they may have an immediate success and enjoy the fruits of victory, but because they feel that if they lose, they will lose prestige and power, and that securities already obtained will slip from their grasp. The bitterness of labor disputes can be better understood when the seriousness of the impelling complexes is adequately appreciated. The farmer also has his grievances and his feeling of struggle with opposing commercial groups. To some extent the farmer's reaction issues from a similar emotion of fear. He feels that the middleman, the milk contractor, the railroad, the merchant, are attempting to thwart his efforts for a reasonable standard of life. Under such circumstances it is inevitable that he should to some extent develop class consciousness. He tries to protect himself by identifying himself with the group to which he belongs. 
This class feeling can easily be exploited, and by appealing to suspicion, by catering to the farmer's emotion of fear, the unwholesome type of rural politician can make personal capital of the farmer's dissatisfaction. The genuine elements of the contest between the farmer and other industrial groups can in this fashion be greatly magnified. The method of accomplishing this is to encourage the farmer's hostilities and suspicions. In other words, the agitator and the axe-grinding politician and the organizer of rural grievances may build upon a foundation of fear a most unfortunate class consciousness. Like all fear complexes, this hostility, when fully aroused, is of no value in working out a program that will conserve the economic welfare of rural people. It may, on the other hand, cloud rural thinking so as to make it difficult for the farming population to obtain in actual practice the economic successes for which they contend. Economic disputes are seldom as simple as they are made by the agitator and exploiter. Imbedded in them are economic laws that human will can never permanently set aside. It is necessary, therefore, that even men suffering from recognized grievances think calmly in terms of cause and effect respecting all the elements that enter into their problem. This thinking is increasingly difficult as emotion mounts, and the less the emotion of fear enters into rural group consciousness, the 
better prepared farmers are to solve their commercial puzzles.

\section{REFERENCES ON FEAR}

Bruce, H. A., Psychology and Parenthood, chap. viii. New

York: Dodd, Mead \& Co., I915.

Crile, G. W., The Origin and Nature of the Emotions, pp. 55-

77. Philadelphia: W. B. Saunders Co., I9I5.

Edman, I., Human Traits and Their Social Significance,

pp. I25-28. Boston: Houghton Mifflin Co., I920.

Frink, H. W., Morbid Fears and Compulsions. New York:

Moffat, Yard \& Co., I 18 .

Harrington, M. A., "The Psychic Factors in Mental Disorder," American Journal of Insanity, April, Igr 5.

Jones, E., Psycho-Analysis, chap. viii. New York: William

Wood \& Co., 1916.

Kempf, E. J., "Charles Darwin, the Affective Sources of

His Inspiration and Anxiety Neurosis," Psychoanalytic Revierw, April, I9I8.

Lay, W., The Child's Unconscious Mind, chap. viii. New

York: Dodd, Mead \& Co., I9I9.

Long, C., "Fear and Fantasy in the Child and the Authority

Complex," Proceedings of the International Conference of Women Physicians, Vol. III. New York: The Woman's Press, I920.

McDougall, W., An Introduction to Social Psychology, pp. 5I-58. Boston: Luce \& Co., I9I8.

Shand, A. F., The Foundations of Character, Book II, chap. ii. London: Macmillan, r9r4.

Sidis, B., "A Lecture on the Abuse of the Fear Instinct in Early Education," Journal of Abnormal Psychology, December, I9I9.

Wallas, G., The Great Society, chap. vi. New York: Macmillan, IgI4. 


\section{VIII}

\section{PUGNACITY, CURIOSITY, WORKMANSHIP, ACQUISITION}

\section{PUGNACITY}

The instinctive character of pugnacity is not open to question. The instinct, however, is in a class by itself; for in order that it be excited purposes of the individual must be thwarted. In other words, its activity is nearly always allied to the previous occurrence of some other instinctive activity, or to some emotion. The instinct functions largely in modern society, although its expression is necessarily modified somewhat by present conditions, as compared with its simpler and on the whole more forceful expressions in earlier times. This milder expression of pugnacious attitudes is, of course, merely a general characteristic, since there are individuals who are as quicktempered and as fierce in anger, so far as their subjective inclinations are concerned, as the most primitive savage could ever have been. The instinct under control performs a considerable service by bringing forth in the individual energy and courage to meet the menace or obstruction which has come across his pathway. 
There are some slight differences in the expression of the instinct in the rural environment as compared with its expression in town and city. These differences may be greatly exaggerated, for the instinct is only slightly influenced by the circumstances of environment.

Rural occupations furnish many opportunities for the stirring up of anger, the emotion of the instinct of pugnacity, because the individual comes in personal contact with so many irritations and obstacles. This is notably true in the handling of animals. The higher animals in their actions have the semblance of human responsibility and purposive decision, and yet a stubborn and stupid unwillingness to conform to man's desires. It follows therefore that he who deals with animals such as dogs, horses, and cattle often feels toward them as if they were persons who were deliberately attempting to oppose him. Under such circumstances, anger is easily awakened. Anyone who has witnessed the teamster whipping his overloaded horse that refuses to climb the hill has often seen in the driver the coming of anger in a most repulsive form. This experience is naturally less frequent in the city than in the country. In the former, moreover, the anger is likely to be suppressed because of the observation of the bystanders and the knowledge on the part of the driver that any great degree of brutality may 
bring him under the power of the law. When similar anger arises in the country there is little, as a rule, to inhibit it. Not only hard characters, but men of highly strung temperaments, quickly aroused, express the emotion of anger with great cruelty in their punishment of animals who are utterly oblivious of the origin of their trouble. Anger can be as freely expressed in family life in the country as it is in the barnyard. The husband may be cruel to his wife, and the father to his children; and unless the community is unusually sensitive to such affairs, or the brutality beyond bounds, not much is likely to be done to curb the instinct of the despot.

Anger arises rather frequently in the country as a result of the personal character of relationships. In order to have full-fledged anger, it is generally necessary to have a clear realization of the force that is hampering one's desires, and this comes about most easily when the obstruction issues from the behavior of some other person. Since in the isolated environment people stand out prominently, it is not difficult for the ordinary collisions between purposes which must ensue in complex society to take on a personal coloring and thereby arouse the pugnacious instinct. Many family feuds and group quarrels of the rural neighborhood start in these outbursts of pugnacity. Things are said or actions are carried out that 
represent only a temporary eruption of anger. But he who receives the injury retaliates in kind. Personal estrangement follows. The quarrel becomes known to the entire community; an audience is provided, and as a result self-assertion reinforces the original feelings of the fighting instinct. A long-time hostility arises, which often gives opportunity for frequent expression of the pugnacious instinct.

Occasionally, as in the case of family feuds, the quarrel is the result of mental aberration on the part of one or both of the principal characters. The suspicious and jealous individual in his ordinary contact with his neighbors is given, through the everyday happenings of the rural community, any number of opportunities to get angry. Since such individuals enjoy the emotion, and without doubt are abnormally urged toward it, it is not strange that we find instances of a long-continued pugnacious attitude and an irrational anger, which, from the point of view of the community's interest, are socially most detrimental. One who has experienced country life at first hand is familiar with quarrels of this sort in churches, for example, where, at a supposed slight, a deacon perhaps withdraws from the church and for twenty years or more does not cross its threshold. The neutral individual who comes into the community inexperienced in rural life cannot understand the force or 
the permanency of such an outburst of anger. As a result of enmities between persons, churches themselves develop feuds. In some towns where there are only two churches, one sometimes finds such intensity of feeling between the two, that it is really ludicrous to the observer. For example, in one small rural community if a book agent coming to the town should sell a book to a member of one church, as soon as this fact became known to the members of the other, he could do no business with them; and the strange thing in this particular instance is that no one in the community has a very clear knowledge as to what the trouble was all about. Somewhere, sometime, years before, an individual quarrel between leading members of the two churches had occurred, and the anger generated passed over into the entire church membership. The vanity that issues from selfassertion and the traditions that are carried forward in an isolated community kept the quarrel fresh, to the utter moral and social demoralization of the community.

\section{CURIOSITY}

Whether curiosity is a pure instinct or not is a problem for the psychologist. At present there is not unanimity of opinion regarding this. There is, however, no dispute about the fact that there are certain attitudes of mind, belonging under the term curiosity, that are expressed with the vigor 
of instinctive behavior. Certainly one knows little of rural life who does not appreciate the significance of curiosity in the country. The biological purpose of curiosity appears to be increase of knowledge. It leads the individual to the strange and partly understood object, that greater acquaintance and understanding may result. In the country, curiosity seems to function abnormally with reference to persons, owing doubtless to the lack of gregarious experience which the individuals feel.

Curiosity in the country allies itself with other instincts, such as self-assertion, fear, and pugnacity. Neighbors are always on the qui vive regarding one another, their eyes ever opened for some peculiar and revealing event. It seems as if they are particularly keen upon discovering unpleasant things, especially such as bring someone into disrepute. It is here that gossip starts. One might define gossip as a depraved product of curiosity. Country people are very fond of gossip; indeed gossip may become one of the popular recreations of the rural group. It is difficult to bring together any gathering without at least one who personifies gossip and who makes use of the opportunity to talk about all manner of things that do not properly concern the public.

The love of gossip is not a possession of rural people because of any inherent peculiarity on 
their part; rather it is the fruit of an isolated and barren environment. If the gregarious life tempts to frivolity, the conditions of isolation lead one easily into gossip. Any group of people with little of interest and much hard work and few contacts finds relief in gossip. The rural community can largely rid itself of this fault which hampers its progress, by multiplying its interests, its contacts with the city, and by encouraging a greater degree of intellectual outlook. It is the school and the church that can contribute most in the stamping out of malicious gossip. People must have something to think of beyond their own personal horizon. Gossip at least provides an opportunity to look out from one's own narrow field of activity. It represents a fine human propensity gone wrong; and even though the habitual gossip may be beyond recovery, the young people can be influenced in such a manner as largely to prevent the gossips of the next generation.

An agricultural specialist of national reputation, experienced in demonstration work, recently made an interesting observation regarding a constructive expression of curiosity on the part of farmers. He said that he has found that of late the best farmers are not content with the mere demonstration of technique. In addition to the knowledge of the method they are asking the why of good agricultural practice. They are becoming 
in a degree scientific in attitude and purely for the satisfaction of their own curiosity after learning how to make use of the application of science as worked out by specialists they seek to know something of the theory behind the technique. My friend is convinced that the most progressive farmers demand a new type of agricultural handbook, one combining theory and practice, giving the why as well as the how, in a way that has never yet been attempted by those writing agricultural books for popular use. This testimony suggests at least that one of the fruits of recent agricultural education will be the lifting of farming more commonly to an intellectual level comparable to that of the professions. The good farmers will no longer demand the quickest statement of method and turn with indifference from the instruction that, by appealing to the instinct of curiosity, attempts to build up an intellectual appreciation of the farming vocation. Those who assume leadership in agricultural extension work surely ought to encourage the farmer's curiosity with reference to the meaning of their own industrial processes. This is one way to assist farmers in developing a higher vocational efficiency and a more satisfying rural culture. Farmers are not different from other workers. They are not all content merely with knowing how to do something skilfully and with profit. 


\section{WORKMANSHIP}

There is a native love of making things one's self that appears early in childhood and seems always to be characteristic of the human being. This desire is by many considered the expression of an instinct called the instinct of workmanship. This instinct has been given various names. Whether workmanship is considered a pure instinct or not, there is universal agreement as to its great importance in modern life. We are all conscious that modern industry largely strips from a multitude of persons any satisfactory sense of creation. The desire for self-expression through workmanship is denied, and the worker is made a mere wage-earner. Of course he is discontented, and however large his wage, and however much he may be able to lift his standard of living by increased income, he is nevertheless irritated by an occupation that denies satisfaction to a tremendous human craving.

As we study the instinct of workmanship as it operates in the rural environment we find that it has a more fortunate opportunity for expression. On the farm one does do things that give a sense of accomplishment. This is especially true of the owner of the farm, who is free to carry out his own purposes. Farm improvements, successful cultivation, skilful animal-breeding, and even the minor making of things with tools, which to some 
extent is still present in the country, are ways by which the instinct reaches self-expression. To a large degree the work of one's hands stands forth in the country as something relatively permanent. The maker of shoes, who carries on one process, never can have the satisfaction of the farmer because he never finishes anything and is no craftsman.

On the other hand, in one aspect agricultural occupation gives less satisfaction for the instinct of workmanship that do some other lines of service that flourish especially in the city. The major operations of the farmer are never permanent. He brings forth a transitory product, which to fulfil its economic destiny must pass from the farmer to market. However splendid the field of corn, it must eventually be cut and pass from sight. However magnificent the yield of fruit, the farmer can feast his eyes on his accomplishment for a very limited space of time. The apples must be picked, barreled, and sent away, and with another season the same series of activities must be gone through. It is an abounding satisfaction, and one that is given to few in modern life, to carry on work, the product of which remains in evidence for a long period of time. This is the rich reward given to the architect; the physician and the teacher share the experience to some extent; the engineer and even the organizer of business find opportunity to minister to the instinct of work- 
manship in a more fundamental degree than is possible for the farmer. The farmer deals with perishable values; he takes from nature largely raw materials; he cannot follow the history of his own products; they go from him, leaving only his economic reward. If the farmer, therefore, is more fortunately situated with reference to workmanship than is the average mechanic or shoe operative, he is nevertheless not so fortunate as are those who are in the professions and in business.

In building up community spirit it is necessary to minister to the instinct of workmanship in the largest degree possible. The standardizing of fruit, for example, and the sending to market of products well packed, under the name of the grower, gives to the farmer some of the sense of responsibility and satisfaction that the builder of a great business feels with reference to his trademark. One of the reasons for petty dishonesty and irresponsibility among farmers, often complained about, is the fact that at present there is so little recognition on the part of the middleman and the consumer of the personal contribution of an individual farmer, who by his own toil has brought forth from nature economic values. The sense of workmanship may well be carried over into community enterprises.

It is of more importance that the people of the community contribute to a community enterprise 
their own labor than a financial gift. If the men of the community more often were enlisted in such an undertaking, for example, as the improvement of school grounds, there would more frequently be a deep and progressive interest in the education of the children. Rural leadership should ever be seeking to minister to this splendid human desire for personal creation, since from it come ethical responsibility, social sanity, and co-operative attitudes of the greatest importance in the rural community.

\section{ACQUISITION}

By most psychologists the desire for accumulation is considered a true instinct. It is a human craving that certainly shows itself in striking forms in the country. In the rural environment there are from childhood many opportunities for accumulation. The country child is hardly ever so poor that he does not have some possessions that he himself made or collected, that are in a peculiar sense his private property. The instinct certainly has had a profound influence in the evolution of human society, and although it may have been overdeveloped, only those who deny the moral right of private ownership will question the utility of the instinct.

In rural places, desire for accumulation naturally allies itself with many of the other instincts. For example, self-assertion is very largely expressed 
through accumulation. The desire for family prestige also forms a very natural union with the instinct of acquisition. There are many reasons why rural people tend to be thrifty. They, more than their city brethren, understand the cost of things produced, because they are always working to produce. A great part of rural thrift, however, is rooted in the desire for accumulation. This is particularly true of an excessive hunger for property. There are few rural communities that do not contain one or more individuals who are misers or who are developing into misers. The miser is without question a complex product, in part probably the result of untoward circumstances in childhood; in part, no doubt, a morbid expression of ambition and love of power, and even a perverted desire for self-display. To some extent, without doubt, the miser is a product of suggestion. $\mathrm{He}$ is influenced by the accumulation of others, and himself accumulates to the largest degree possible. In a still larger measure he is the culmination of habit. Beginning with reasonable thrift, he ends with a pathological craving that makes it possible for him to endure intense suffering and constant privation rather than to expend a proper share of the wealth he has created. Of course, the miser is no peculiar product of the rural environment, but he stands out more clearly there than he ever can in the city, and without 
question there are influences that work to produce him more frequently in the country. Occasionally a miser will violate his usual behavior and make strange and unexpected expenditures. Such revelations of the discord of character are most curious and naturally attract the attention of the psychologist. It would seem as if they bear testimony to the fact that the causes operating to produce the miser are of various and conflicting character. For example, the inordinate desire for extravagant expenditure on the part of the growing youth is finally too much curbed. In order to check his inherent disposition toward careless spending the maturing adult develops his inhibitions beyond reascn. In conquering his original weakness, in the way Adler makes clear, he produces the opposite vice. The youthful spendthrift becomes the mature miser. Occasionally, however, the earlier cravings break forth and, although habitually penurious, he surprises his neighbors by a spasmodic generosity or extravagance.

In the country property largely tends to be in the form of real estate. This desire for land seems to be an unreasonable appetite on the part of the farmer. Men become "land-poor" because of an irrational craving to extend the size of their holdings. They deny themselves reasonable standards of life and subject their families to the conditions of poverty that they may have under their own title 
more and more acres of land. It is a peculiar form of miserliness which seldom flourishes outside of rural communities. The farmer would be happier and enjoy a higher type of social experience if he more often set himself against his peculiar temptation to add more and more land to his farm. He sometimes is so eager to get, that he has limited opportunity to use. Although unable to cultivate thoroughly what he has, he buys still more. He smothers his finer ambitions in a crude materialistic craving for acreage.

The instinct of acquisition has unquestionably a conservative influence over the farmer's thought. $\mathrm{He}$ particularly holds to the right of private property, and it would require a mental earthquake to transform him into a sympathizer with socialist or communist practices. His influence upon legislation is always conservative with reference to matters that have to do with the rights of property. This attitude, as has been previously said, has other causes than the desire for acquisition; but without doubt this is one cause, and good proof of this is seen in the conservatism that owning his own home produces in the average city worker. The instinct of acquisition as it operates in the rural community both advances and retards progress. In the degree that individuals attain a high standard of life and wholesome social outlooks, the instinct will be forced to take its proper place, 
and less prestige will come from mere ownership and more from skill and character.

\section{REFERENCES ON PUGNACITY, WORKMANSHIP, CURIOSITY, ACQUISITION}

\section{PUGNACITY}

Edman, I., Human Traits and Their Social Significance, pp. III-I5. Boston: Houghton Mifflin Co., I920.

Hall, G. S., "Anger as a Primary Emotion, and the Application of Freudian Mechanism to Its Phenomena." Journal of Abnormal Psychology, July, r9r5.

McDougall, W., An Introduciion to Social Psychology, pp. 6I-64 and chap. ii. Boston: Luce \& Co., rgi 8.

Richardson, R. F., The Psychology and Pedagogy of Anger. Baltimore: Warwick \& York, Inc., I918.

Ross, E. A., Principles of Sociology, pp. 44-45. New York: Century Co., I920.

Tead, O., Instincts in Industry, chap. ix. Boston: Houghton Mifflin Co., Igr8.

\section{CURIOSITY}

Edman, I., Human Traits and Their Social Significance, pp. 74-75. Boston: Houghton Mifflin Co., I920.

Jung, C. G., Analytical Psychology (C. E. Long, transl.), chap. iv. New York: Moffat, Yard \& Co., I916.

McDougall, W., An Introduction to Social Psychology, pp. 59-6r. Boston: Luce \& Co., I9r8.

Shand, A. F., The Foundations of Character, Book II, chap. xvii. London: Macmillan, I9I4.

Tead, O., Instincts in Industry, chap. xi. Boston: Houghton Mifflin, I918.

Wallas, G., The Great Society, pp. 45-56. New York: Macmillan, IgI4. 


\section{WORKMANSHIP}

McDougall, W., An Introduction to Social Psychology, chap. xiv. Boston: Luce \& Co., I9r8.

Morgan, J. J. B., "Why Men Strike," American Journal of Sociology, September, r920.

Tead, O., Instincts in Industry, chap. iv. Boston: Houghton Mifflin Co., Igr8.

Veblen, T., The Instinct of Workmanship. New York: Macmillan, I9r4.

Wallas, G., The Great Society, pp. 327-39. New York: Macmillan, I9r4.

\section{ACQUISITION}

Hobhouse, L. T., Wheeler, G. C., and Ginsberg, M., The Material Culture and Social Institutions of the Simpler Peoples, pp. 243-53. London: Chapman \& Hall, I9I5. Lowie, R. H., Primitive Society, chap. ix. New York: Boni \& Liveright, I 920.

McDougall, W., An Introduction to Social Psychology, chap. xiv. Boston: Luce \& Co., I9I8.

Tead, O., Instincts in Industry, chap. v. Boston: Houghton Mifflin Co., Igr 8.

Wallas, G., The Great Society, pp. 291-97. New York: Macmillan, I9I4. 


\section{IX}

\section{PLAY}

The play impulse is so inherently characteristic of man that it is generally regarded as an original instinct. Play appears spontaneously in children. Animals, especially the young, also play. To deny that play is an instinct in no degree minimizes its naturalness or its importance. Play has at any rate the vigor of an instinct. It expresses itself as spontaneously as any instinct; it is as rich in social significance. Watson defines play as "a form of instinctive activity the stimulus to which is unquestionably in doubt." I Several theories have been advanced to account for the origin of play, but none of them seems completely satisfactory. The explanation of the source of the play impulse remains a problem for future psychology.

There is no doubt of the sociological results of play. (Play naturally stands in contrast with work. Work is consciously directed activity leading to the accomplishment of a set purpose. It is effort because it requires a concentration that forbids the spending of energy upon movements that do not contribute to the chosen task. Play on the

${ }^{2}$ Watson, Psychology from the Standpoint of a Behaviorist, p. 260. 
other hand carries with it a sense of freedom. Desire seems at liberty to follow its successive inclinations. Work, therefore, tires one because of its intrinsic lack of interest, its monotonous repetition, or its denial of other activities more appealing to the person. Work too long-continued or too nerve-tiring brings inner irritation. The sense of inward freedom is replaced by the feeling of coercion. When the work finally comes to an end there is a craving for stimulation and under stress of disagreeable, unvaried, or excessive work a demand for violent, exciting recreation.

This relation between work and play reveals in part the social significance of play. Play is tonic. Play also is renewal of spirit. It brings the person exhausted by work back to normal attitudes. It refreshes the mind as sleep restores the physical energy of the body. It follows therefore that play acts to preserve the normality of a social group.

From a social viewpoint play is a therapeutic agency. Even physiologically play conserves health. Recreation has been called "the positive phase of the health program." A striking testimony to this fact has been expressed in a recent book of travel by the following observation:

I am persuaded that the Polynesians, from Hawaii to Tahiti, are dying because of the suppression of the playinstinct, an instinct that had its expression in most of their

${ }^{x}$ Second National Country Life Conference, p. 118. 
customs and occupations. Their dancing, their tattooing, their chanting, their religious rites, and even their warfare, had very visible elements of humor and joyousness. They were essentially a happy people, full of dramatic feeling, emotional, and with a keen sense of the ridiculous. The rule of the trader crushed all these native feelings. ${ }^{\text {I }}$

Wholesome social life requires an adequate amount of play and recreation.

Play caters to one of the original motives for the existence of any social group. People have always been drawn into association because of their need of emotional satisfactions. Social grouping has never been exclusively for economic wellbeing or physical protection. There also have been emotional results springing from the togetherness of the people that have held them in association just as certainly as have gain or safety. Any environment or locality that does not furnish a considerable quantity of emotional satisfactions that can be commonly enjoyed lacks a prerequisite of social wholesomeness.

Play especially yields-opportunities for emotional expression. It is by nature social rather than exclusive. It affords relief from the restrictions, the irksome necessities, and monotonous tasks of the workaday life. It renews the ancient racial sense of freedom. Through the emotional quickening of play one shakes off weariness, dis-

I O'Brien, White Shadows in the South Seas, p. I64. 
couragement, egoistic reproaches, and the feeling of deadly routine.

Play also quickens thinking. It removes selfconsciousness and other inhibitions that restrict psychic activity, and permits the mind to function in spontaneous, pleasurable experiences. Play therefore has an intellectual significance. It gives the mind a quickness and resourcefulness that show themselves outside the play circle; and as a result the society that makes good use of play has a vigor of mind that is a considerable social asset.

Play draws people together by melting the consciousness of difference or distinction. It affords a social meeting place where all may gather, forgetting such circumstances as tend toward separation and dislike. Ross has expressed this vividly as follows:

At American colleges in the Orient, athletic sports have been found to be arch-propagandists of the doctrine of human equality. Youths of diverse races, religions, ranks, and castes find their level on the football field, where a prince may be tackled by a peasant, and on the baseball diamond, where the son of a pasha may be caught out at first base by the son of a licorice grower. At first the haughty, slow-moving scions of the ruling race-Turks, Druses of Lebanon, or Manchus-stand by watching the "madness" of the Americans and wondering why the strangers do not spare themselves exertion by hiring servants to play for them. But presently the pulse of 
youth quickens, the game "gets" them, and they forget their rank in novel excitement and pleasures. ${ }^{x}$

Play and recreation, by bringing people to act together, quicken the social sympathies. This explains their influence in teaching co-operation. From the days of the primitive man to the present, one of the social functions of games and sports has been the development of a sense of solidarity. Men and women feel together, think together, act together, and thus build a foundation of common understanding and respect.

Play has ever been one of the effective methods of enforcing social discipline. The control that issues from sport and games does not carry the atmosphere of outside coercion, for it is organically incorporated in the inner life of the person who comes under their spell. Play offers an opportunity for the training and testing of leadership, and at the same time those who should follow are taught to accept leadership loyally and wholeheartedly. No social influence in modern life disciplines the individual more effectively and with less irritation.

Any consideration of the social value of play reveals a weakness in present-day rural life. The people of the country take life too seriously and are too much engrossed with material interests. They do not play enough. Too little provision is

${ }^{`}$ Ross, Principles of Sociology, p. 403-04. 
made for recreation. This verdict is pronounced by every student of country life. If it be answered that the economic conditions are such that country life must be keyed almost exclusively to the processes of earning a living, then the economic system is itself at fault. Rural people cannot share the advantages of modern life to a reasonable degree unless they can obtain opportunity for a quantity of play experiences. The craving for play has been greatly stimulated by modern conditions, and the leisure resulting from laborsaving machinery has been largely expended in more abundant recreation. Yet the farmer has relatively fallen behind. He has lost many of the enjoyments of his predecessors, notably those that were characteristic of the pioneering days. To be sure he has gained others. Especially has he borrowed recreational facilities developed in the cities; but compared with the city dweller he has suffered loss.

There has been in the past so much economic struggle on the farms that there has developed a morbid philosophy of life which regards play as a superficial desire, a waste of time. Fathers have even wandered so far away from wholesome attitudes as to covet the time spent by their children at play, believing that, with so much work to be done, games ought to give way to more serious concerns. They have said, Why should one play 
when there are so many useful ways of "getting exercise"? Holidays have been interpreted as belonging only to "city folks." Life on the farm in such cases becomes a never-ending round of soulcrushing toil.

Any denial of the legitimate claims of recreation shows itself in social consequences detrimental to wholesome association. There can be no doubt that the group-mind of certain country localities exhibits the unfortunate results of a neglect of recreation. The emotional needs of the people, refused wholesome expression through recreation, are satisfied in ways that add little to the welfare of the community. Much of the recreation, frowned upon and treated as inherently foolish or evil, has been driven into the leadership of those who, by low moral purpose, encourage vicious forms of enjoyment. Recreation there is, of course, for always there must be some type of play-activity; but it is profitless, trivial, aimless, and often, as has been suggested, even bad. The churches instead of helping to solve the problem look upon the recreational situation with indifference, hopelessness, or even with antagonism. When the churches become repressive and teach asceticism, then indeed the social life, especially for the youth, is bound to be pernicious. What such churches do not see is the baneful effect their attitude has upon a splendid source of community morality. They throw 
away a most important social instrument, which, when directed by constructive moral leadership, is prolific in its uplifting influences. This situation has been well expressed by Warren Wilson:

The tradition of the church has been opposed to amusement and recreation. The church of our fathers recognized the moral possibilities of play by calling all play immoral. The early Quakers filled their records in the eighteenth century with denunciations of "frollicks." Consciously they denounced amusement, acting no doubt in a wise understanding of the rude, boisterous character of the pioneer's social gatherings. Only unconsciously did the Quakers cultivate the spirit of recreation in their social gatherings. It was permitted to have but few and repressed opportunities. The decadence of the Quaker church is probably due, in a considerable measure, to their stubborn unwillingness to see both sides of this question. They saw that recreation was immoral. They refused to see that its possible moral value was as great as its moral danger.

Extensive correspondence with working pastors, by means of a system of questions sent out from a New York office, has brought this result. In answer to the question, "What amusements of moral value are there in the community?" the answer, "Baseball, boating, tennis, golf, bicycling, etc." A smaller number of recreations was named in answer to the inquiry for immoral sports. The subsequent question, "What is your position before the community?" brought from the minister very often this answer: "I am known to be opposed to all sports." Few ministers realize the inconsistency of this position. They stand before the community as the professed advocates of public and private morality, and they stand also before the community as the professed and violent opponents, 
often, of the public sports which are known to the young men and workingmen generally as promoters of ethical culture and moral training. Is it any wonder that the churches, in these communities, are often deserted by the common people?

There certainly has been of late a radical change in the rural church policy regarding recreation. The church is more and more accepting responsibility for recreational leadership. The preaching less often antagonizes wholesome play. The moral by-products of good recreation are openly recognized, and conscientious effort is put forth to assist in solving the recreational problem of the community. Pastors are themselves learning to play even in violation of the habits of a lifetime. At conferences recreational problems are frequently discussed, and only the dwindling minority continue to advocate an unnatural, morbid type of Christianity.

The lack of play experience in the country environment shows itself in other psychic attitudes than those of the emotional or moral field. Without question anyone who has too little play lacks the full use of his mental powers. A dulness of mind is likely to permeate all his mental contacts. Imagination is feeble. Judgment is easily narrowed and made partial. Hostilities are more quickly created by trivial differences of opinion. A

r Wilson, Evolution of the Country Community, p. 197-98. 
deep sense of isolation often creeps in, and the person is over-cautious, easily discouraged and unfriendly to new ideas. It is a wise and shrewd psychology that has led rural reformers to stress group games in preparation for new ideas. The purpose of the sports is clearly something more than "to liven up the blood." This technique of playing first and lecturing afterward bears testimony to the refreshing effect of play upon one's mental equipment.

It is in the difficulty of rural co-operation, as critics of rural life have often observed, that we have the most apparent social limitation due to lack of play. Men who as children have had no personal knowledge of co-operation through games find it difficult to co-operate successfully even when they seriously try. They are without a basic preparation for adult co-operation. They do not know from personal experience the meaning of group solidarity as do those who in village and city come under the sway of game loyalty. Such farmers find individualism ever intruding in their attitudes, and although they organize for cooperation they remain a mere collection of individuals, because they never achieve group unity. This represents a great loss, for at all points-in business, recreation, politics, social attainmentrural people cannot obtain a reasonable degree of modern culture and prosperity unless they stand 
together and work together. The establishment of community recreation is often prerequisite to the working out of a co-operative program.

Rural leadership must recognize that difficulties inherent in the country environment hamper recreation. The fewer the people in a locality, the greater the limitation put upon the forms of play that can be successfully maintained. Machinery may make it possible for a smaller population in the country districts to produce the food supply of the nation, but this economic fact in no degree lessens the social problem. If there are in a given district few people, widely scattered, the difficulty of bringing them together for recreation is a very real one. The less often the people can get together, the less easily they associate. Anyone who plays infrequently is likely to be awkward when he enters any kind of sport, and his knowledge of this is sure to make him reluctant to join in a public game. Rural sections that have a decreasing population are at the same time increasing their recreational problem. Rural conditions, moreover, do not offer the facilities for certain forms of recreation. Such sports as baseball and football, for example, are with great difficulty maintained in the open country. Generally speaking, games in which all can join as contrasted

- with athletic contests have the larger amount of success, 
At present two opposing policies regarding rural recreation are advocated. Some desire to imitate in the largest degree possible the urban types of recreation. Others would reduce these importations to the smallest point feasible and encourage the rural people to develop their own peculiar forms of play. The wise program for rural recreation will attempt to harmonize the two policies.

Rural people are like urban people in their desire for forms of recreation that naturally flourish in the larger centers. To the extent that their environment will permit, rural people will for some time to come demand just such recreation as is popular in the cities. For example, the phonograph and the moving picture do not appeal less to country people than to those of the city. The moving picture makes a universal appeal, not one limited to a certain environment. But it is necessary to recognize that the small population in the rural environment forbids country people certain types of amusements. Recreational programs should not deny country people any wholesome amusement that they can successfully borrow from the town or city. They are in no danger of enjoying too much gregarious pleasure. They need all the wholesome city recreations they can support. At best they are likely to have too little. They are restricted necessarily because of the limitations of their environment. 
On the other hand, there is so much opportunity in the country for play and social activities that the city people cannot possibly have, that it will be most unfortunate if rural recreation consists only of that which is imitated from the city. The physical surroundings give play advantages that city people travel miles out into the country to enjoy. The familiarity of one person with another, due to the small population in the rural district, permits play to have a community character that under no circumstances can be duplicated in the city. The common experiences of the country folk color all rural association with elements that are truly distinctive. It would be folly indeed for rural people to throw away their intrinsic, environmental opportunities for recreation and content themselves with the little that they can import from gregarious localities.

It is because rural people are so neglectful of their recreation possibilities that many of the students of country-life conditions stress the danger of imitative programs. Rural recreation must be largely self-maintained. It cannot be furnished by commercial interests as are so many city pleasures. Therefore the inhabitants of our country districts need to discover their own recreational resources. They possess the environment richest in recreational opportunities. They must, however, put forth effort to utilize these possibilities. In the 
city recreation goes after one. In the country it must be obtained mostly by earnest seeking. Even in the field of recreation there is for the countryman no easy, parasitic way to satisfaction.

Reading does not yet receive the emphasis it deserves in programs for rural recreation. It represents one of the most satisfying forms of relaxation. It also passes easily from a recreation to an intellectual process. It would be a great advantage to rural people if they read more, and especially if they read with greater discrimination. This statement does not mean any comparison of the reading of rural and urban people to the disparagement of the former. Everywhere society is suffering because of the careless use made of opportunities for reading. In the country there are many who, were they once awakened to the advantages of good reading, would use to the utmost any opportunity given them. Indeed, one cannot know rural life in the concrete without calling to mind family after family where reading is maintained on a level that would put to shame the usual reading of urban people.

It is still difficult in the average country district to get enough good books and periodicals for those who love reading. It must be frankly confessed that reading as a means of recreation will never appeal to the majority of any locality. Sports, games, and "pictures" are more universally inter- 
esting. Reading, however, if given a fair chance, will enlist more patrons in the country than at present enjoy its relaxation. The roadway to good reading ought in every community to be as inviting as the social conditions permit. Even if few read, among them are sure to be the most thoughtful of the community. By increasing the reading public and by encouraging good taste in the choice of books the social mind of the entire group is elevated, broadened, and invigorated. At every point in the community life the good influence of the readers shows itself. The pastor of the church is likely to feel less intellectual loneliness. The teachers of the schools have a nucleus of supporters who appreciate the better type of instruction. The readers of the community provide contact with the world of ideals and in one way or another become interpreters to the group as a whole.

Some years ago when engaged in social work in a frontier New England community twenty miles from the nearest railroad, I learned at first hand the important service even an inadequate library can render an isolated rural community. I happened to board with the family that housed the small collection of books that someone had given the town. The library contained about a hundred books, mostly standard fiction. For so small a library it was on the whole a good selection. 
Although I was there during the summer, the busiest season of the year, it was surprising to see how well patronized the library was; this, in spite of the fact that people calling for books admitted that they were reading for the second or third time the volume they carried away. There was considerable complaining because so much of the library was "stories." The people especially wanted popular science, travel, and good biography. It seems a shame that rural readers do not have the facilities to satisfy their needs. Little effort seems to be made by anyone to direct their reading. As a result the books of the home are generally the product of some book agent's exploitation. When there are libraries the books are apt to cater to the least thoughtful type of reader. Science, especially agricultural science, is largely lacking. I have gone over the books of rural and village libraries in order to discover whether the enterprising farmer is given any consideration in the buying of books, and have seldom found any modern, useful books on an agricultural subject. In most rural communities there is no organized interest in the reading of the people.

The reading needs of the women of the country-especially the mothers - ought to be carefully considered in any library program. The women as a rule read more than do the men. Occasionally they read to the men and children, 
especially on Sunday afternoons. It is particularly important to encourage the mothers to read, for upon them more largely than upon their husbands rests the responsibility of the culture of the home. Every rural library should contain the best books procurable upon such subjects as the training of children, the health of the family, household management, and home decoration.

Some states are trying to serve rural readers by traveling libraries. This movement ought to extend to every state in the union, for it is one of the most promising forms of public service. The best type of American farmer will never consent to be forced into the peasant class. Rural people insist, and rightly insist, upon having a reasonable share of modern comfort and culture. Some of them want good reading, and their need should be adequately met by public policy. If they cannot get the proper reading otherwise, it should be brought to them.

One cannot know the rural social mind intimately without recognizing that there exists in some degree a lack of confidence in a type of reading that performs a large public function. The bulletins issued by some state experiment stations and by the extension department of some agricultural colleges have not in the past been prepared with the discrimination that their social importance justifies. Not all scientists, certainly not 
all connected with experiment stations, are fitted to carry on original experiments of value to the farmer. Even though greater and greater care is exercised in the directing policy of experiment stations and extension departments, bulletins appear that because of the too limited practical experience, or the lack of adaptability on the part of the author, fail to win the confidence of the farmer. His belief in the unreliability of a specific bulletin is likely to color his attitude toward a form of publication of greatest value to him. It is certainly clear that farm bulletins must less and less "sell ideas" as propaganda, and must more and more become careful, well-matured business documents. It is evident that this fact is being recognized by those who direct the policy of our experiment stations.

The farm journals have a tremendous influence upon the thinking of country people. These papers, although of course differing in value, are all good. From a literary and vocational viewpoint they certainly are much more useful than they were a decade ago. They are becoming increasingly scientific in spirit and without exception have a serious interest in the social welfare of country people. They cater to the rural family as an institution and serve husband, wife, and children.

With the advent of rural free delivery the weekly edition of city newspapers has lost its hold 
upon rural people. It has been replaced by the daily paper. The farmer in large measure now thinks in both rural and urban terms with reference to current events. He knows much more about city happenings than urban people do about country matters. Anyone who wishes to understand the present rural mind must fully appreciate this fact. Farmers are not merely sensitive to the environment in which they are physically placed. They are also, in the content of their thinking, constantly influenced by the reading which brings them in contact with an environment as wide as the interest of the press. This is one of the fortunate conditions that operate to prevent in America a narrow, peasant type of rural culture. The group mind of the American farmer, although influenced by locality in its thought content, is more distinctly a vocational class mind than a mere echo of physical environment.

\section{REFERENCES ON PLAY}

American Country Life Association, Proceedings First and Second Conferences, Greensboro, N.C.

Breckinridge, S. P., and Abbott, E., The Delinquent Child and the Home, chap. ix. New York: Charities Publication Committee, I9I2.

Cabot, R. C., What Men Live By, Book II. Boston:

Houghton Mifflin Co., I9I4.

Curtis, H. S., Play and Recreation for the Open Country.

Boston: Ginn, I9I4. 
Gillin, J. L., "Sociology of Recreation," American Journal of Sociology, May, I914.

Groves, E. R., Rural Problems of Today, chap. vii. New York: Association Press, r918.

$\longrightarrow$, Using the Resources of the Country Church, chap. vi. New York: Association Press, 1917.

Hart, J. K., Educational Resources of Village and Rural Communities, chaps. xi and xiv. New York: Macmillan, I9I4.

Patrick, G. T. W., The Psychology of Relaxation, chap. ii. Boston: Houghton Mifflin Co., r9r6.

Phelan, J., Readings in Rural Sociology, chap. ix. New York: Macmillan, I920.

Robinson, E. S., "The Compensatory Function of MakeBelieve Play," Psychological Review, November, I920. Ross, E. A., "Adult Recreation as a Social Program," American Journal of Sociology, January, I9r8.

- Principles of Sociology, pp. 604-r7. New York: Century Co., 1920.

Siedenburg, F., "The Recreational Value of Religion," American Journal of Sociology, January, I920.

Sims, N. L., The Rural Community, pp. 714-84. New York: Scribner's, I920. 

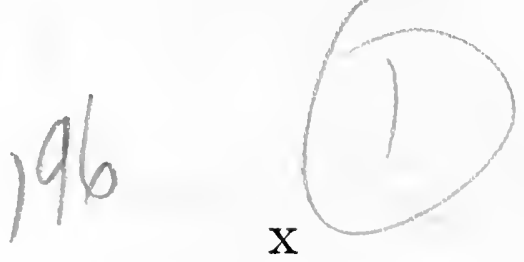

\section{THE COUNTRY CHURCH AND THE RURAL MIND}

The social and psychic influence of the church upon the life of country people is likely to be underestimated rather than overestimated. The student of country-life problems cannot gauge the significance of the church in country life merely by its membership or by the attendance at its services. To an outsider the country church may seem to have very little contact with the life of most of the people; one who resides for any length of time in the country finds, however, that in many unexpected ways he detects the influence of the church. In the country environment it is an institution that occupies a unique position. The idealism, the culture, the community spirit, indeed all practical social service centers in the church; and however low grade the organization may be, or however unfitted its leadership as represented by the minister, it nevertheless performs an important function. It suffers at present, as does the urban church, from a relative loss of prestige. A large number of country people neither support any church nor attend any religious service. But these people do not live their life without influence from 
the church of their locality. The city church necessarily occupies a narrow field as compared with the country church. The latter performs a function impossible for the former, simply because in the country environment there is no substitute for the organization that consciously ministers to the moral and spiritual needs of the people.

Of course the country church is largely what the minister makes it, or perhaps more truthfully what the minister has made it. His influence is a community force in a sense that can never be true of a city pastor, however famed the later may be as an orator or however gifted in organization. In the rural setting the minister's personality is revealed in large proportions, and its weakness and its strength become common knowledge. It is true that churches hamper ministers, and that communities prove unworthy of a fine type of ministerial guidance. Yet this actually means that the leadership of the past has developed a church or a community that cannot sympathize with a more progressive or a more morally substantial quality of service.

Although the rural minister's work is tremendously important, nevertheless it is a very difficult and trying and sacrificing form of service. In the first place, the rural minister is greatly underpaid. His salary often does not represent a living wage. He cannot expect to live upon his salary and bring 
up a family decently and meet his social obligations without constant worry and financial struggle. His living problem, which may be aggravated by the failure of the church to pay his salary promptly, wears out his idealism and makes it increasingly difficult for him to perform the service he ought to render. He also finds that in becoming pastor of the church he has assumed burdens of which he was not conscious. For example, he often finds himself hampered in his work by the petty tyranny. of officials of the church, or he recognizes that he is expected to cater to the sense of importance of some of those who pay liberally toward his support. It is not strange under such circumstances that the young rural minister soon wishes for a call to a larger church, where he may look forward to more income and greater freedom.

This problem of the minister's salary must be met in one or more of the following ways. The farmer's income must be increased. The minister's prosperity is closely allied to that of the farmers among whom he works. He cannot expect to be paid much more than the average income of his associates without his ministerial efforts becoming futile. He must partake of their usual life; and their prosperity is a condition of his own adequate payment. The minister's lot could also be easier if there were fewer churches in the country communities, and if the people were more just and 
reasonable in contributing to the work of the church. It does not follow that a prosperous farming community is always ready to do justly by the minister. One who knows this problem in the concrete is familiar with case after case where the church drives a hard bargain and does not support the minister as it should. The fact is that the average church official has little understanding of the community advantage of a well-paid and efficient pastor. Of course, where competition between many denominations eats up the available church support, it is impossible to pay a really adequate salary. In many localities the only way that a minister can be given a reasonable salary without receiving support from outside the community is by federating churches. To be sure, country churches can be subsidized by wealthy city churches and by denominational boards. This policy may be justified in specific instances, but as a rule the country church must expect to raise its own finances. If the country is not over-churched and if churches really minister to the community there will be less and less reason for subsidies.

In the second place, the rural minister suffers from a lack of suitable training. There has been until recently little effort on the part of theological schools to train men for the rural field. Rural service seems to have been conceived as a sort of apprenticeship for the town and city church. The 
young man entering the rural ministry has had little understanding of the peculiarities of rural work. Often his point of view has prevented his appreciating rural opportunity. He has tried to do what he could not do; he has not known how to try to do the things most important and most promising. Because of this the condition has come about which has been so well described by Warren Wilson. ${ }^{1}$ Fortunately the theological school is changing its policy and is making a very decided effort at present to familiarize the student with the character of the rural field, even to prepare some candidates specifically for the country ministry. This certainly ought to issue in a higher degree of efficiency in the rural ministry, and in a more actively functioning rural church.

A third difficulty experienced by the country minister, especially by the well-trained minister, is the handicap he feels because of cultural limitation. He cannot easily obtain books and magazines that he needs for study. $\mathrm{He}$ misses the inspiration of contact with the speakers and writers of great reputation. He ministers to a group of people who do not share, at certain points, his most captivating interests. To be sure, he recognizes the substantial worth of the farmer's point of view, but still he misses, somewhat, contact with the scholar, the man of literary interests,

${ }^{x}$ W. H. Wilson, Evolution of the Country Community, p. 185. 
the experienced social worker. In conversation with rural ministers one finds frequently that they complain of their intellectual isolation. Without question it is more difficult to maintain a high standard of mental activity when the stimulus of intellectual rivalry and sympathetic association is lacking. This drawback, although inherent in the rural environment, can be reasonably overcome, providing the minister can afford books and travel.

Another irritating obstacle in the way of rural ministration is the professional standing of rural service. The financial and other limitations of the rural work have given urban service an unreasonable prestige. It requires real moral courage and penetrating insight for an able man to remain in the rural field when he senses the general attitude of his professional associates with respect to the country pastorate. Naturally the orator in the ministry is most likely to be in the city church. Aside from this one gift, urban preachers can claim no superiority over their country brethren. Scholarship, organizing skill, educational insight, and the ability deeply to influence people, all flourish as naturally in the country pastorate as in the city. In certain respects the country church, as compared with the urban, is a more difficult and even more useful field of service, and it is entitled to the highest degree of professional rank. 
Another difficulty in the way of satisfactory church work in the country is the insufficient equipment of most country churches. The best type of minister in these days, one who tries to carry out in country places a modern church program, as a rule is hindered by the inadequacy of the equipment at his command. The building is likely to be merely a gathering place for preaching services, sometimes not even well adapted to this purpose and seldom affording much opportunity for community work. Moreover, to carry out the kind of program that would adequately serve the life of the community requires an expenditure of money that frequently prohibits the effort. Ferhaps this handicap is overestimated. The skilled minister may be able to accomplish more than is supposed possible with a very limited physical equipment. Happily, in some communities the federation of several churches has enlarged the equipment of the minister by giving him one building for preaching, another for religious education, and perhaps still another for recreation. While the meagerness of equipment may be overstressed, it deserves recognition when one attempts to estimate the social influence of the rural church.

In spite of all the difficulties that beset the rural pastor, he nevertheless is performing a very important rural work, duplicated by nobody else. The quantity and the quality of his influence in the 
community rest primarily on his personality and his conscious development of the resources at hand. Some of these resources are native to the rural environment and are more effectively used under country-life conditions than in towns and cities. The rural environment tends to emphasize, to the thoughtful and well-trained minister, the causal relationships in the community life which he serves. The country minister has the decided advantage over his city brother of seeing the full life of his parishioners. This experience of knowing the complete personality of his church associates may be both discouraging and inspiring. The city minister must be content in most cases with only a superficial knowledge of his church members. The rural clergyman, knowing more thoroughly those whom he serves, is given opportunity for real cause-and-effect thinking with reference to human conduct $\mathrm{He}$ lives in a social laboratory teeming with psychological and social material. If he has the wit and aptitude for a scientific viewpoint he becomes expert in diagnosis in the field of human behavior, one of the most baffling and inspiring fields being worked by modern science. In order to do justice to this opportunity around about him, the country minister must fellowship with science. Nothing will encourage the scientific viewpoint more than the study of some physical science such as geology, astronomy, botany, or 
anthropology. Such a study promotes scientific habits. It enriches the physical environment in which the clergyman finds himself and tends to establish sympathy and understanding between the farmer and the minister. The farmer is by no means a thorough-going scientist, but today he respects science and to some extent follows it. Therefore he is closer in his usual experiences to the scientific than to the philosophical or the literary viewpoint. He can appreciate more deeply the scientific proficiency of his pastor than he can attainments farther afield from his ordinary interests. The country minister who thinks in terms of cause and effect heroically and precisely with reference to concrete, current events in his own community places himself in the forefront of modern moral service. $\mathrm{He}$ becomes skilled in ministering with diagnostic penetration to the profound needs of the people whom he knows in a way impossible to the minister who does not meet his problems with causal thinking.

Any minister who analyzes character in the country environment is impelled toward an increasing recognition of the significance of childhood. He sees vividly the tremendous influences of childhood which stretch all through the adult's life. Such a pastor emphasizes his work for parents and his work for children. He becomes profoundly interested in the recreation of the community, in 
its cultural standards, in its neighborhood experiences, and especially in its schools. He attempts to minister not so much by what he personally does as by what he can induce others to do. He develops a strategy and becomes a tactful but persistent social leader. He has, if he abides in the community for any length of time, the satisfaction of seeing character influenced by movements and organizations and social conditions which he inspired. Thus the genius of his social leadership permeates the life of the entire community and influences human habit at every point.

The minister in the country finds another important resource in the rural environment. He learns the advantage of familiarity between persons. The closeness of social contact in the country establishes a basis for ethics and for social responsibilities by providing a foundation through intimate interrelationships. Whatever else may be true regarding the character of neighborhood association, the country minister can at least bank upon the interest each person has in all the others. Although this interest may be trivial and the judgments passed upon one another brutal or unfair, it is nevertheless an advantage to work in a community where the people are bound together by common concerns and not grouped into classes largely indifferent to one another. 
The rural minister obtains advantage at another point where at first it seems to him that he merely suffers handicap. Rural people very largely must produce their own social resources. In the urban environment professional classes become expert in giving the rest of the people recreation, instruction, and fellowship. Each human need is catered to by an organization generally founded on a commercial basis. Country people to a large extent must develop among themselves opportunities for the satisfying of their own social cravings. Under such circumstances the people of the country cannot bring their games or parties or organization interests to the high level of those furnished in the city; but they derive more benefit from their personal contributions than can ever come from the passive reception of what others provide for money. It is unfortunate that there has come to be such an unwholesome craving for the importing into the country of the same type of enjoyments and activities as normally happen in the urban environment. This tendency represents a real social deterioration, and the far-seeing minister will meet it in large measure by bringing back a better appreciation of the social opportunities than country people can themselves provide.

The rural clergyman who takes his task seriously and analyzes it in the spirit of science finds himself forced to the conclusion that his church 
must minister to the entire life of the community. It can afford to neglect nothing wholesome. It must be concerned with the health of the people, for if it is not, the health of the people will not be safeguarded as it should be. It must concern itself with the schools, for without its inspiration they cannot function to their highest capacity. It must give thought to the recreation of the people, or it will find the community undermined by vicious influences. It must have interest in the economic success of the people, or it cannot have the means for the development of high standards. It must look out for the reading of the people, or an enormous rural advantage will be lost. It must socialize the moral motive of the people, or they will fall behind in the rapid moving on of social thinking. The program of the rural church, therefore, must be complete, stressing first one thing and then another, and never interpreting its service in a narrow way, never substituting theology for religion, or trivial problems for moral obligations. It requires a preaching and a teaching that enter life-problems in their specific relationship to community life in a way seldom demanded of city ministers. The city church is only one of the moral forces of its environment; the rural church in the sense of an organization has a monopoly of the moral and spiritual forces, and therefore is prepared to undertake a strategic and specific pro- 
gram impossible to its sister-church. Because it is ministering to a constantly changing life, the country church can never reach finality in its efforts; but it can arrive at accomplishments which become the basis for a still more complete and more successful religious program. In this way the church ministers to rural culture, and its influence pervades the entire social life of the people.

For such a program the church must have adequate leadership. It must plan its campaign with eyes directed to the future. Thinking must anticipate new conditions and prepare the community for definite changes. The age is rapid, and its new situations rush upon us with a swiftness that gives some a sense of helplessness. The worldwar increased this tendency, and it especially operated to do this in our rural districts. Rural leadership must govern its purposes by $a^{\circ}$ farsighted vision. It must make a program that is more influenced by what is coming into the country than by what is already there.

Wise leadership must minister in concrete terms and with a real appreciation of causal conditions, if the rural districts are to have the program needed. In method, the problem is one of efficient organization and employment of the control processes that affect human conduct. Skill is required as well as vision. Management becomes a deter- 
mining factor. The church cannot escape from the rigid laws that govern human association. What is done can be done rightly only if the directing leadership has a substantial grasp of actual conditions and the processes of influential control. Ministers frequently shun the atmosphere of indifferent diagnosis, but only to their undoing as social servants. Without the coloring of personal desires, the community situation and the church situation must be seen just as they are.

Emphasis upon team play is also demanded of rural church leadership. Unless communities can be brought into fellowship and co-operation there can never be a suitable moral program for the rural districts. No community in the country in this modern time can adequately function in moral or civic isolation. There must be found some new way of bringing into active association country communities that share the same problems and that need to pool their resources in order most effectively to meet some of their problems. This emphasis upon the getting-together spirit is also required within the community itself. The local forces need to become more sympathetic and more interrelated. Moral and civic isolation will forbid the construction of the rural program these days demand.

The church must certainly share its moral and spiritual responsibilities with the school. In spite 
of the vast accumulation of human experience, there is still in urban and in rural places a feeble grasp of the power for civic and moral welfare contained in public education. In a large degree our schools still serve traditions rather than the needs of people of flesh and blood, and our systematic education outside the schools is next to nothing. And yet enough is being done to reveal what a powerful instrument for progress public education is soon to become.

The church must bring rural people to a realization of the significance of the social contribution of an efficient country civilization. Popular notions must be reconstructed, that the importance of urban society may not be so greatly exaggerated. Christianity must once again control industrial concepts; and those near the soil, making the basic cosmic contribution of human endeavor, must be given the social recognition that false ideals have denied. This is fundamental, for the present social changes tend more and more to create in the individual the necessity of feeling social significance and social relationships. Economic justice for the farmer is included in his social appreciation.

Revelation must be made of the resources of the rural community. At present in few rural places are the natural resources making a reasonable yield in moral results. It is this which gives 
some communities the aspect of moral and social destitution-a poverty-spot from which vital persons are expected to flee. A program that appreciates the moral resources of the rural community can remedy this unhappy situation.

Finally, the church must set its back against an unreasonable individualistic interpretation of life, an interpretation justified neither by science nor by the conditions of modern life. Ethics must be socialized. Morality must be stated in terms of wide association. Religion must function in forms of normal service. This imperative part of a comprehensive social program for the country most of all will test the vitality of the rural churches.

REFERENCES ON THE COUNTRY CHURCH AND THE RURAL MIND

Butterfield, K. L., The Country Church and the Rural

Problem. Chicago: University of Chicago Press, rgrr. Earp, E. L., The Rural Church Movement. New York: Methodist Book Concern, Igr4.

Galpin, C. J., Rural Life, chap. xi. New York: Century Co., Igr8.

Gill, C. O., "Social Control: Rural Religion," Publications of the American Sociological Society, Vol. XI.

Gill, C. O., and Pinchot, G., The Country Church. New York: Macmillan, r9r3.

Groves, E. R., Rural Problems of Today, chap. iv. New York: Association Press, IgI8. 
Groves, E. R., Using the Resources of the Country Church.

New York: Association Press, I9I7.

Phelan, J., Readings in Rural Sociology, chap. xv. New

York: Macmillan, 1920.

Sims, N. L., The Rural Community, pp. 692-7I4. New York: Scribner's, I920.

Vogt, P. L., Introduction to Rural Sociology, chaps. xvii, xviii. New York: Appleton, I9I 7.

Wilson, W. H., The Church and the Open Country. New York: Missionary Educational Movement, Igrr. 


\section{$\mathrm{XI}$}

\section{THE PSYCHOLOGY OF RURAL ORGANIZATION}

In organization the rural community has lagged behind the urban. On account of size and diversity, the social and commercial interests of the towns and cities necessarily have to organize. These conditions inevitably force the organization of every group of people associated in a common undertaking. An unorganized enterprise in such a complex environment has little chance of maintaining itself. On the other hand many of the influences of rural life tend to make country people unwisely negligent in the organization of their common interests. Fortunately this is not now so characteristic of country people as formerly it was. The contact of country and town along lines of commerce has driven into the consciousness of rural people the necessity of their being better organized as a means of self-protection.

Successful organization rests of course upon a basic psychology. Now that this is being more generally recognized, it is becoming the modern practice in any undertaking that has to do with people to attempt first of all a psychological analysis. To a greater degree than most people realize, 
behind the successful functioning of large corporations and powerful organizations there has been built up a detailed and definite body of psychological principles. This is, however, largely confined to urban affairs. As a result organizations that conserve rural interests, except as they pattern after urban institutions, have little psychological material of value in the construction of their policies. Nevertheless no one doubts that psychological laws operate upon country people just as certainly as upon city people. Country-life institutions need a double psychological basis. There are certain principles of mind behavior that condition any organization whether it serves people living in the urban or in the rural environment. The larger, the more complex, and the more in contact with urban life the rural organization, the more it is concerned with these common principles. Since any rural organization ministers to country people and adapts itself to them, it follows that in addition to this common, basic psychology behind all successful organization there are other psychic factors that must be taken into account. In so far as country people because of their environmental experiences have their separate social mind, that fact must be reckoned with by those who shape the policy and by those who carry on the undertakings of any organization that hopes successfully to minister to rural needs. 
The urban group mind is more generally understood than the rural group mind, and therefore rural organization has more of the element of experiment, more of the trial-and-error procedure, than is true of city organizations. The value of psychology in treating any social problem and particularly in the development of organization policy is a recent discovery, for it is only of late that psychology has had knowledge enough of the operation of law in human conduct to be of much assistance to practical men. The greater part of the valuable information psychology is beginning to collect regarding the social behavior of men and women has been developed within our own generation, particularly during the last ten years. The full meaning of this remarkable progress of a fundamental science cannot as yet show itself. A new source of social assistance has been provided for all who attempt to influence men and women for evil or for good. Until recently those who studied psychology at college found the science content with a description which was largely formal. Today every department of human conduct is being investigated that scientific principles may be established, and to a considerable extent we have a body of knowledge that discloses causes as they actually work in the association of men and women.

We have the beginning of a rural psychology. The farmer, of course, shares the common psychic 
life of his period and his locality. In part psychology must understand him by its knowledge of the common experiences and practices of his race, his nationality, his geographical section, his political party, his religious faith, and his social ideals. No rural organization prospers long in dealing with its problems unless it gathers a rather clear notion of this part of the farmer's life. The farmer, however, has special vocational characteristics that appear in his psychic life. These provide the special field of rural psychology. These psychic characteristics which to an extent separate rural and urban people, tillers of the soil and other workers, have much to do with determining the policy of any rural organization. These characteristic psychic elements result from the farmer's vocation, his physical environment, and from rural traditions. These experiences of the farmer necessarily give him a somewhat different point of view from that of the man who mines, or serves his customer across the counter, or works in the factory at his machine. Much has been written regarding the special vocational experiences of the farmer. We notice how concerned he is with weather and other physical circumstances largely outside his control. From the study of primitive man we see the beginning of that difficulty which the farmer still experiences, the distance between planting and harvest. The muscular and varied toil connected ordinarily 
with farming, the complexity of farm work, the farmer's need of being both producer and seller, are other distinctive experiences that issue in psychic traits. Locality-influences also appear in the farmer's life. By the very fact that he tills the soil, he is bound to accept a greater degree of solitude than belongs to most other men. He lives in his workshop, so to speak. He travels great distances over the same area in the course of the year. The farmer, therefore, not because he is different from other workers, but because of the nature of his work and his place of livelihood, accumulates his own special psychic characteristics.

The progress that modern psychology has recently made in its understanding of the working of the mind has been largely because of the clearer knowledge that has been obtained regarding the human instincts and the psychic compounds that under the influence of social experience are derived from these instincts. Whether it functions in country or city, any organization to be successful must pay heed to this knowledge. The psychology of rural organization is therefore mainly the application to the field of organization of the information we have regarding the operation of the instincts in the rural environment.

Any person interested in rural organization must consider seriously the place the gregarious instinct occupies in rural life and the ways in which 
it influences the social structure of the rural group. The study of country life reveals the increasing importance of the gregarious attitude in modern life by showing clearly the handicap the rural environment carries because of its non-gregarious characteristics. The rural sociologist senses this situation as no one else can, for he realizes how largely the modern gregarious wants hamper the successful functioning of country life. The situation, as we find it in these days, emphasizes the need of more organization and better organization in the country. To as large an extent as possible it is most necessary that the farmers find in their own local organizations the means of satisfying to a more reasonable degree their deep and natural desire for gregarious experiences. Organization of course awakens and stimulates the gregarious interests. It is equally true that the gregarious instinct furnishes an indispensable basis for organization. Any organization must have first of all, before it can be well established, a fund of common interests, the result of the association of persons who share a common experience. It is the gregarious instinct primarily that draws people into association and holds them in contact until a degree of common sympathy results.

Occasionally it happens that individual farmers have for so long suppressed their gregarious tendencies that they find themselves unable naturally 
to organize with their fellows. It requires sometimes a tremendous economic pressure to bring these persons temporarily under the influence of organization. If country life were to become so destitute of organization that the majority of the farmers no longer felt any gregarious hunger, not only would organizations become impossible in the country, but the farmer would be excluded from the larger part of modern life. Any organization that enters the country must assume that some of the persons to whom it attempts to minister have lost much of their original gregariousness or are suffering because they feel that they are gregariously destitute. The second group will welcome the organization, but the first need its ministration more. Fortunately the gregarious instinct is generally strong enough even in the most isolated sections to maintain a considerable desire for association among the people of the neighborhood or locality. Where there is no will to be together, it is hopeless to expect the development of any pull-together spirit.

The working of the gregarious instinct teaches us one caution which unfortunately has not always been observed by workers among country people. Organizations cannot be developed in urban offices by people steeped in urban psychology, working for urban objectives, and then be transferred bodily into country sections and forced upon country 
people without a high percentage of failure, even though subsidized from the urban center with money, personnel, and enthusiasm. The organizations under such circumstances cannot thrive. In other words, we must permit each gregarious group to work out its own type of organization. Genuine rural statesmanship requires that leadership use its skill to bring country people together, but that it abstain from coercing the organizations that country people maintain when they are brought together. This lesson is particularly difficult for the group-minded leader who has complete confidence in the psychology he has deduced from his urban experience, and who cannot appreciate success that expresses itself contrary to his expectations. It remains an axiom, however, for any rural organization that it must measure its results not by what it does for the farmer, but by what it gives opportunity for the farmer to do.

At this point we discover the strategy of rural organization. Rural organization must provide for local autonomy in a greater degree than is necessary for organizations that draw from city constituencies. There must be in the organization a sincere attempt to develop democratic control. Local leaders must be given a real voice in the policy of the organization, for any rural enterprise that creates mere local dummies cannot $m$ aintain itself anywhere in the country with any 
vigor. Experience and common sense enforce the necessity of every organization that tries to enter the rural field recognizing the need of utilizing local leadership to the utmost.

This policy of making the largest possible use of local leadership is also strengthened by the consideration demanded by the self-assertive instinct. No person who has had experience in movements for country-life betterment needs to be told that rural organization is largely influenced by the selfassertive instinct. This instinct flourishes in both the country and the city organization, and it would be impossible to show that it has more influence on the one than on the other. However, the working of the instinct appears more clearly on the surface in the rural organization because of the smaller number and greater intimacy of the persons in association; and when the instinct is not under the control of a wholesome community discipline it becomes a stumbling-block in the way of successful rural organization, for from it come trivial hostilities, unreasonable prejudices and suspicions, and even bitter feuds.

In so far as any organization functions in the country, however, it tends to eliminate this narrow spirit of hostility. The self-assertive instinct also shows itself in the spontaneous suspicion of many country people toward any unfamiliar or outside organization. It would seem as if the natural 
leaders of the community feared a loss of their power through the incoming organization. All these circumstances create a very serious obstacle to the rural organization. It must use in each locality the leaders already in existence, or develop new ones. This means that it finds itself drawn into the competitive atmosphere of the community. Its career may hinge upon the choice of local leadership, and there may be no opportunity for a just or logical choice. Potential leadership in the organization may not be developed because of the covetousness of those who have had in times past a considerable degree of power. On the other hand, this instinct like all others can be socially controlled. One significant purpose of rural organization is to teach country people the advantages of expressing self-assertion in wholesome group experience. We must have in the country more and more a higher type of self-assertion. This can come only from better functioning of great social institutions. The school, for instance, must profoundly change its entire spirit. It must look upon itself as a social institution, and it must measure its success by the ability of its graduates to share wholesome social experiences. It must turn its back upon its present standards, and not permit individual distinction or any other form of individual success to seem a reasonable measure of its efficiency. The same is true of the church. Unfortunately, until 
of late, the church in the country has given way to the line of least resistance, and has emphasized individual attainment to a much greater degree than has the city church. It is the country church that needs to preach the social gospel. Every institution that has flourished in the country has been guilty too often of stressing individualistic motives. In spite of this, however, it is in the country that democracy can most successfully be carried forward. The members of the small community are naturally in contact and do have a real interest in one another. This provides the basis for a wholesome social life when once, through education, the self-assertive instinct is led to express itself primarily in forms of behavior that conserve the welfare of the group as a whole. This sublimation of self-assertion is just now one of the great problems of civilization. The organization that goes into the country to exploit the selfregarding instinct, and with no respect for the permanent welfare of the people is, however strong and flourishing it may be, an enemy of progress, merely adding greater social burdens to a people already too much divided by their trivial interests and unreasonable animosities. Its program is fundamentally unsound.

The influence of fear appears in rural organization. There is at times, as has been stated, an attitude of instinctive hostility on the part of 
rural folk with reference to new projects and unfamiliar organizations. This is due to a suspicion which at bottom is rooted in the fear instinct. Much has been experienced by farmers in their economic life to encourage this attitude of fear and suspicion. In some sections of our country there is much more timidity on the part of farmers than in other parts. Isolation increases the timidity; inexperience with business ways gives opportunity for the fear to operate. Any specific exploitation which the farmer in his business relations may have suffered at the hands of middlemen and other representatives of city business tends to give vigor to the instinctive reaction of fear when new social or business organizations are advocated.

In part his present economic situation rests upon a substantial fact which the farmer only partly senses. As a workman and as a capitalist he is less organized than his interests demand. This lack of organization on his part makes it difficult, even impossible, for him to secure his reasonable share of economic and social satisfactions, since he is forced into competition with large bodies highly organized. $\mathrm{He}$ has been taught, particularly by the daylight-saving legislation, how sensitive his government is to group pressure. $\mathrm{He}$ knows from experience that urban labor or urban capital can more easily unite in a close and selfprotective organization than can he. This fear 
that he may be sacrificed by government policy because of his lesser strength in organization as compared with urban interests is making him more open to new and better organization. Rural statesmanship should take advantage of this situation and should reveal to the farmer that he is hampered not only in his economic life, but also in his social experiences, by his lack of organization. In this way the farmer will learn that he can best protect himself and can best satisfy himself socially by co-operation and by unity; and thus putting aside the instinct of fear, he will develop wholesome social confidence. Organization in this manner will replace a defense motive with a positive, constructive attitude to the great advantage of the rural community.

Any organization that attempts to make headway among country people must pay due regard to the influence of the instinct of possession. It is the business of any organization in the country frankly to recognize the instinctive craving for possession, and by catering to it to gain a firm basis for popular support. The community organization can skilfully transfer much of this desire for possession from the area of personal ownership to that of the community. Then the community in a peculiar sense becomes the possession of the farmer, who believes himself in very truth a part of it. Its prosperity becomes his prosperity; its 
reputation gives him a sense of pride. If by lack of organization or by lack of success in the functioning of organizations the community has little of which to boast, the farmer must necessarily satisfy this instinct of possession with things that belong to him and his family exclusively. Unless the instinct can to some extent be lifted up to the level of community expression, it becomes an obstacle to any effort to bring the people together. This need of creating a sense of community possession explains the advantage in any rural movement of enlisting the people in some concrete physical improvement. Through the eye the farmer sees the results of the organization, and if he has had part in the movement, has a consciousness of personal contribution which more than anything else is likely to feed his enthusiasm for still greater community progress. City dwellers frequently feel a deep sense of community possession. St. Paul was neither the first nor the last urbanite to boast of his citizenship. But the actual personal contribution that most city people make to their community must necessarily be small. The man of the country, in comparison, may have the sense of direct and important contribution, even though he be only an average citizen. It seems strange that rural reform has not more often fostered this sense of community possession. Organizations enter the country under the spell of urban efficiency 
and appeal to the purely selfish individualistic interests of the farmer. Then when such organizations fail because individualism goes so far as to forbid a common program, the organizers marvel at the narrow interests of the farmer. As a matter of fact they have reaped the harvest they themselves planted.

Rural organizations do well to keep in mind the strength of the parental instinct in the country. No matter what the nature of the organization may be, it should pay heed to the parental interests of country people. The most commercial of organizations should include in its program something of advantage to the children and young people. There should always be some appeal to the family interest as such. This appeal may be as impressive as one more directly related to the personal interests of the adults. This fact explains the influence that has been exercised in practical rural improvement by the best type of school teacher. When she has demonstrated her genuine interest in the people, especially in the children, and her practical judgment, the community has usually supported her work with enthusiasm and confidence. Her position is one of power because she ministers as no other can to the parental interests of the community. On the other hand, the parental instinct may prove the undoing of a ruralwelfare movement. Here it is that an organization 
may easily go on the rocks. Rural community life can be broken into fragments by an unwholesome development of parental instinct as quickly as in any other way. When a poorly organized community, living on a low level of social thinking, enters into family competition, the parental instinct will sweep all reasonableness away and even establish feuds that will endure for a great length of time and terribly injure the welfare of all the people.

The organization in the country that has the greatest responsibility for the socializing of the parental instinct is the church. It can interpret the social meaning of parenthood with an appeal and an authority not equaled by any other institution. Fortunately, of late the church has discovered how large an asset it has in the parental instinct, and is becoming increasingly efficient in using parental love for the socializing and idealizing of life. The school also, especially in the city, is taking very seriously its vocational and social obligations. In the effort to meet present social responsibilities, modern education, both in its content of study and in its methods, is surely being radically changed. The rural organization that wishes to have a fund of common interest from which it can draw forth vitality will in its policy in every way possible encourage the school to function as a social institution. The organization 
will realize that in so far as the children of today are led into social attitudes, to that extent it is sure to have incoming material that will enable it to prosper.

There can be no doubt that organization has a large and happy rôle to play in the immediate advancement of American rural civilization. Progress will be hindered, however, if the institutions that enter the rural field do not function in substantial harmony with the rural mind. At a time when so many social organizations have awakened to the possibilities of service in the rural field there is need of caution. Ambition to serve may easily pass over into a subtle form of exploitation. The policy of any effort looking toward rural improvement must be directed by those who from personal experience appreciate the genius of rural society. The rural field cannot without serious and lasting injury become an experimental ground for the trying out of alien and conflicting programs. Rural people are bound to be wary of social programs that are constructed by outsiders. It is well that they are. Any substantial undertaking must enlist local support; nowhere are there such abundant rural resources that they can safely be spent without the best possible promise of success.

President Butterfield has given wise counsel to those organizations that are ambitious to minister to rural need: 
Each institution should have a program composed of a series of definite objectives, together with lists of methods worth trying in order to gain these objectives. This program will vary from time to time, will be different in its application to different parts of the country and even to different communities in the same state or county. It cannot be a hard and fast outline of methods for the local community, but it ought to be suggestive and helpful -devices that have been a success. A so-called program may be merely a piece of writing which anybody with a facile pen can evolve. A real program is hammered out of the thought and experience of the people who are doing the work, and has the advantage of keeping before them something clear-cut and definite, something that they can come back to every little while and check up in order to discover whether they are making progress. ${ }^{x}$

The insistence upon a cautious and mature program on the part of those institutions that attempt to enlist rural support does not of course mean that those already in the field are justified in a "Hands off!" attitude toward newcomers. There is real need of new social activities in the country. In any case, service belongs to the institutions that are best fitted to render it. The point is that a desire to help is, in itself, insufficient credentials. There must be an understanding of the psychic problems involved. The rural field is not a mere duplicate of the urban. There are some essential differences that must receive recognition in any social undertaking.

I Butterfield, The Farmer and the New Day, p. I27. 


\section{REFERENCES ON THE PSYCHOLOGY OF RURAL ORGANIZATION}

Butterfield, K. L., The Farmer and the New Day, pp. 84-2II. New York: Macmillan, rgrg.

Douglass, H. B., The Little Town, chap. ix. New York: Macmillan, rgrg.

Gillette, J. M., Constructive Rural Sociology, chaps. xv, xvi. New York: Macmillan, I9Ig.

Groves, E. R., Rural Problems of Today, chap. x. New York: Association Press, I9I8.

Morgan, E. L., Mobilizing the Rural Community. Amherst, Mass.: Massachusetts Agricultural College, Extension Bulletin No. 23, September, I9r8.

Morse, R., Fear God in Your Own Village. New York: Holt, 1918.

Rainwater, C. E., Community Organization. Monograph, Southern California Sociological Society, Los Angeles, February, I920.

Sanderson, D., "Democracy and Community Organization," Publications of the American Sociological Society, $\mathrm{XIV}, 83-93$.

Sims, N. L., The Rural Community, pp. 826-916. New York: Century Co., I920.

—, "Rural Socialization," Political Science Quarterly, March, I920.

Vogt, P. L., Introduction to Rural Sociology, chaps. xiii, xiv. New York: Appleton, r9r7. 



\section{INDEX}





\section{INDEX}

Acquisition, 193-94

Adler, A., 69

Anger and animals, 1 28-29

Bulletins, I60-6r

Butterfield, K. L., quoted, I98

Canadian city drift, 28

Census of 1920,31

Character analysis, I 72

Children and fear, I I I-I 6

Church: equipment, I 70 , and recreation, I5O-52; and schools, $177-78$

City drift, 24-43

Civilization and agriculture, I6-I 7

Class consciousness, $\mathrm{I} 24$

Classification of interests, 4

Collections, 138

Competition, 74-75

Conservatism, 141

Co-operation, I48, I53-54, 177

Crowd, 54

Cruelty, I I 4, I 5

Curiosity, I $3 \mathrm{I}-32$

Curtis, H. S., quoted, roo-ror

Dramatic hunt, 17

Edman, I., quoted, 3

European city drift, 24

Exploitation of farmers, I 25

Family: attitude toward agriculture, 9०; competition, 93-94; feuds, I 29-3I
Farm journals, 161-62

Farmers' characteristics, I3

Fear instinct, I08-I I

Fear and organization, I I 7-1 8

Federation of churches, 170

Feeble-minded, ror

Gillette, J. M., quoted, 30

Gossip, 132-33

Government and gregariousness, 53

Governor Eberhart, 43

Gregarious instinct, 46-55

Gregarious leader, 73

Guinchard, J., quoted, 26-27

Haggard, R., quoted, 26

Housekeepers, IO3

Howitt, W., quoted, $120-22$

Illegitimacy, ror

Individualism, I 79, 191, 195

Industrial conflict, I 24

Influence of rural church, 16465

Instincts, number of, 4

Intellectual isolation, $168-69$

Intellectual value of play, 147 , I 52

James, W., quoted, 108-9

Land hunger, $\mathrm{I}_{40-42}$

Leadership, 148, 173, I 76-77

Leonard, A. G., quoted, I9

Local leaders, $80-82$, 188-90 
Loss of youth, 37

Lowie, R. H., quoted, I 10

MacDougall, J., quoted, 28

McDougall, William, quoted, 49-50, 86-87

Merritt, E., quoted, 33, 34-35

Minister and science, $17 \mathrm{x}-72$

Miser, 139-40

Modern industrialism, 24

Mother love, $86-87$

National welfare, viii

Neolithic epoch, 13

New England, 33, 37-38

O'Brien, $145^{-46}$

Organization, $181-82 ;$ and fear, 19I-93; and gregariousness, I85-88; and $\mathrm{pa}$ rental instinct, 195 ; and selfassertion, $189-9 I$

Percentage of males, 33-34

Perishable values, $136-37$

Pity, 94-96

Play, 144-52; and co-operation, $148,153-54$; and social discipline, I48; and social health, I45; and social unity, 147; and work, I45, r49-50; lack of, I48-49, 152; urban imitation in, I 55-57, 174

Potential leadership, I 16, I90

Precocious courtship, 99

Primitive agriculture, $\mathrm{I} 2-\mathrm{I} 3$

Prize contests, $77-78$

Propaganda, 52

Psychological era, I

Psychological laws, I $8 \mathrm{I}-83$
Psychological progress, 183

Pugnacity instinct, 1 27-28

Race friction, I 18

Reading, I 57-60

Recreational policies, $155-56$

Ross, E. A., quoted, $3^{6-3} 8$, I $47^{-48}$

Rural church program, $175^{-76}$

Rural education, 63

Rural libraries, 160

Rural minister: lack of prestige, I69; salary, I65-67; training, $167-68$

Rural psychology, 7, 8, 9, 18385

Rural racial type, 20-21

Rural statesmanship, 77

Savage agriculture, I 2-20

Schools and urban viewpoint, 57

Scientific attitude of farmers, I33-34

Second Wisconsin Country Life Conference, 25

Self-assertion, 67-85; and evolution, 70

Sense of accomplishment, 136 , 1 $38-39$; in community projects, $137-38$

Sense stimulation, $60-62$

Sex, 97,98

Social diagnosis, I71, 177

Socializing: of the parental instinct, 196 ; of the schools, I 78 , I90, 196-97

Social nature of play, $\mathrm{r} 46$

Social sanity, vii

7 Suggestion, 55-60

Sweden, 26-27 
Tragic experiences, 1 22-23 War and city dweller, 22

Trotter, W., quoted, 47-48 Watson, J. E., quoted, 4, 5

Urban increase in United States, 28-3I

Urban pride, 194

Villager, $75^{-76}$

Williamson, R. W., quoted, 18

Wilson, W., quoted, 105, $15 \mathrm{I}^{-}$ 52

Wage earner's discontent, $6 r$, 83,135

Workmanship, 135-37, 194

World-war, 50-5I

Wundt, W., quoted, I05 

This book is DUE on the last date stamped below

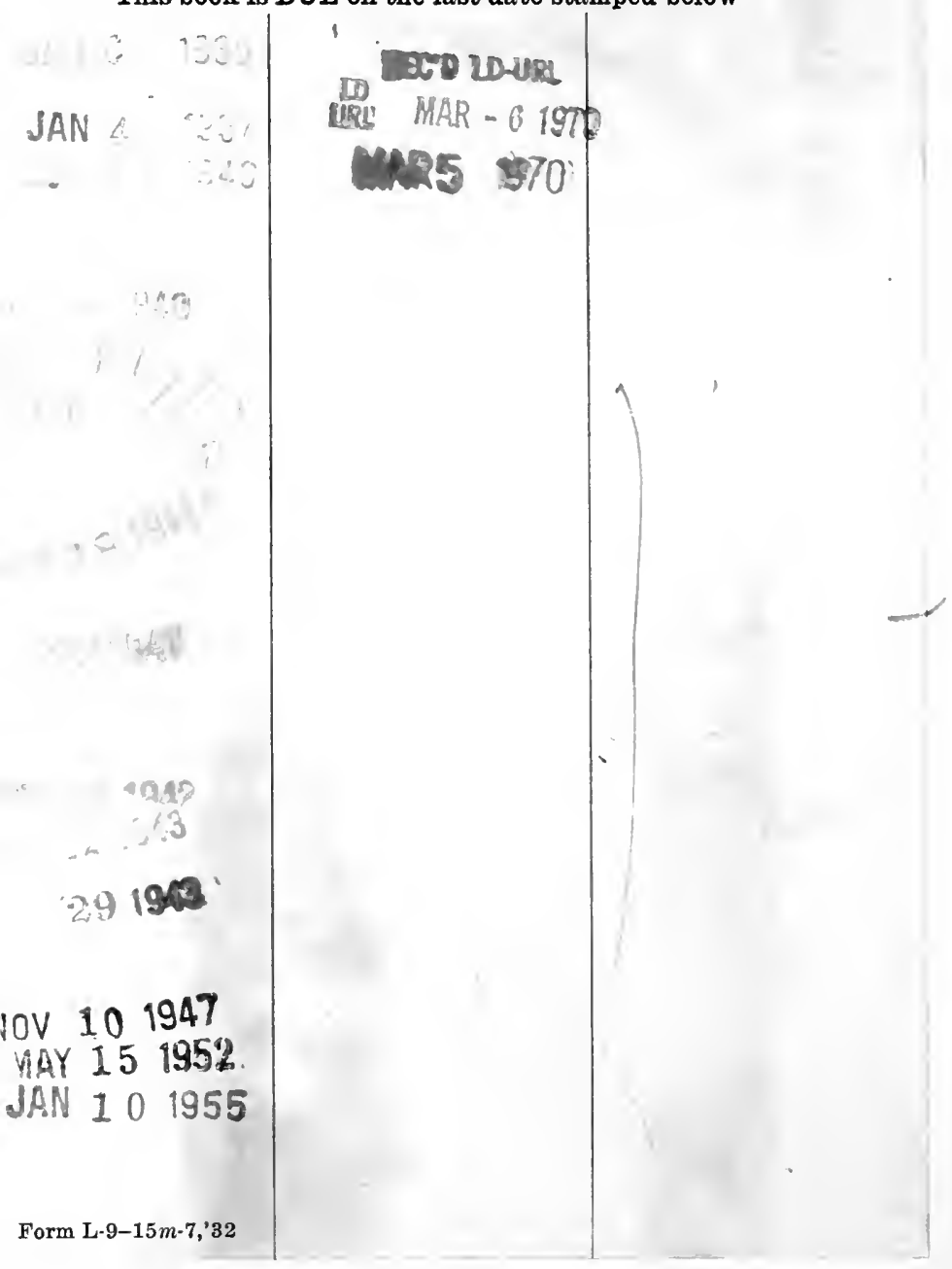




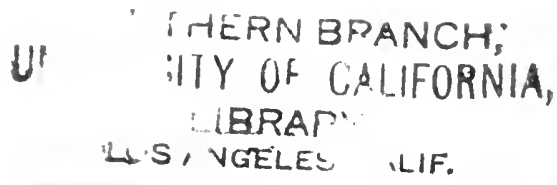




\section{$8060 \% 308$}

3. $30 \%$

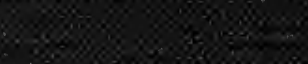

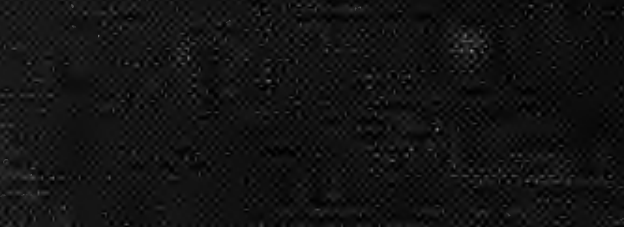

$3 \sin ^{2} 0$

$\left(\begin{array}{c}2 \\ 0\end{array}\right.$

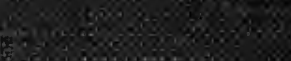

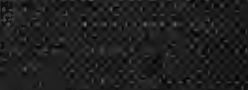

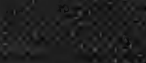

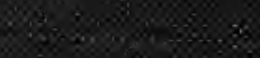

$6 \times 6 \times 30 \%$
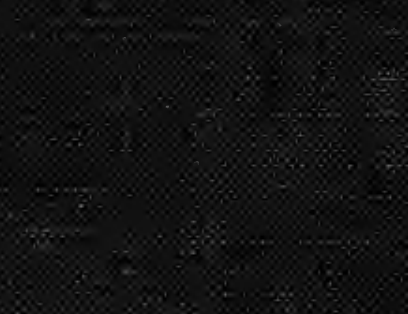

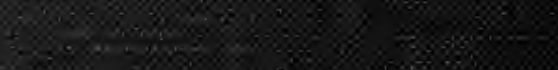

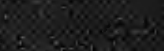

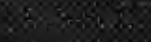

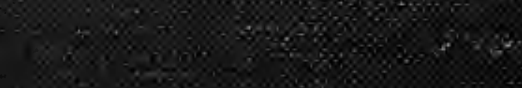

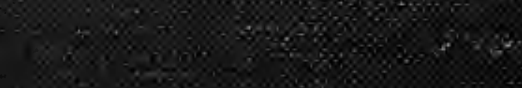

\%

$30.8 \times 2 \times$

$6 \%$ \% $8 \%$ 